Florida International University FIU Digital Commons

6-2-2010

\title{
Essays on International Lending and Increasing Returns to Scale
}

Thomas J. Snyder

Florida International University, tsnyd001@fiu.edu

DOI: $10.25148 /$ etd.FI10080416

Follow this and additional works at: https:// digitalcommons.fiu.edu/etd

Cart of the International Economics Commons

\section{Recommended Citation}

Snyder, Thomas J., "Essays on International Lending and Increasing Returns to Scale" (2010). FIU Electronic Theses and Dissertations. 227.

https://digitalcommons.fiu.edu/etd/227

This work is brought to you for free and open access by the University Graduate School at FIU Digital Commons. It has been accepted for inclusion in FIU Electronic Theses and Dissertations by an authorized administrator of FIU Digital Commons. For more information, please contact dcc@fiu.edu. 


\section{FLORIDA INTERNATIONAL UNIVERSITY}

Miami, Florida

\section{ESSAYS ON INTERNATIONAL LENDING AND \\ INCREASING RETURNS TO SCALE}

A dissertation submitted in partial fulfillment of the

requirements for the degree of

DOCTOR OF PHILOSOPHY

in

ECONOMICS

by

THOMAS JACK SNYDER

2010 
To: Dean Kenneth Furton

College of Arts and Sciences

This dissertation, written by Thomas Jack Snyder, and entitled Essays on International Lending and Increasing Returns to Scale, having been approved in respect to style and intellectual content, is referred to you for judgment.

We have read this dissertation and recommend that it be approved.

Mihaela Pintea

Prasad Bidarkota

Hassan Zahedi

Cem Karayalcin, Major Professor

Date of Defense: June 2, 2010

The dissertation of Thomas Jack Snyder is approved.

\begin{tabular}{c}
\hline $\begin{array}{c}\text { Dean Kenneth Furton } \\
\text { College of Arts and Sciences }\end{array}$ \\
\hline Interim Dean Kevin O'Shea \\
University Graduate School
\end{tabular}

Florida International University, 2010 


\section{ACKNOWLEDGMENTS}

I would like to especially thank my advisor Professor Cem Karayalcin. He has spent a lot of effort and time helping me during this process, and I will always be indebted to him. I would also like to thank Dr. Mihaela Pintea and Dr. Prasad Bidarkota for their time and effort, especially in regards to the job market. I am also appreciative to Dr. Hassan Zahedi for his committee service. Finally, I would like to thank the University Graduate School for the Dissertation-Year Fellowship. 


\title{
ABSTRACT OF THE DISSERTATION \\ ESSAYS ON INTERNATIONAL LENDING AND \\ INCREASING RETURNS TO SCALE
}

\author{
by \\ Thomas Jack Snyder \\ Florida International University, 2010 \\ Miami, Florida \\ Professor Cem Karayalcin, Major Professor
}

Standard economic theory suggests that capital should flow from rich countries to poor countries. However, capital has predominantly flowed to rich countries. The three essays in this dissertation attempt to explain this phenomenon. The first two essays suggest theoretical explanations for why capital has not flowed to the poor countries. The third essay empirically tests the theoretical explanations.

The first essay examines the effects of increasing returns to scale on international lending and borrowing with moral hazard. Introducing increasing returns in a twocountry general equilibrium model yields possible multiple equilibria and helps explain the possibility of capital flows from a poor to a rich country. I find that a borrowing country may need to borrow sufficient amounts internationally to reach a minimum investment threshold in order to invest domestically.

The second essay examines how a poor country may invest in sectors with low productivity because of sovereign risk, and how collateral differences across sectors may exacerbate the problem. I model sovereign borrowing with a two-sector economy: one sector with increasing returns to scale (IRS) and one sector with diminishing returns to 
scale (DRS). Countries with incomes below a threshold will only invest in the DRS sector, and countries with incomes above a threshold will invest mostly in the IRS sector. The results help explain the existence of a bimodal world income distribution.

The third essay empirically tests the explanations for why capital has not flowed from the rich to the poor countries, with a focus on institutions and initial capital. I find that institutional variables are a very important factor, but in contrast to other studies, I show that institutions do not account for the Lucas Paradox. Evidence of increasing returns still exists, even when controlling for institutions and other variables. In addition, I find that the determinants of capital flows may depend on whether a country is rich or poor. 


\section{TABLE OF CONTENTS}

CHAPTER

PAGE

I. INTERNATIONAL LENDING WITH INCREASING RETURNS

AND MORAL HAZARD

I.I. Introduction _ _ _ _ _ _ _ _

I.II. Model for a Small Open Economy

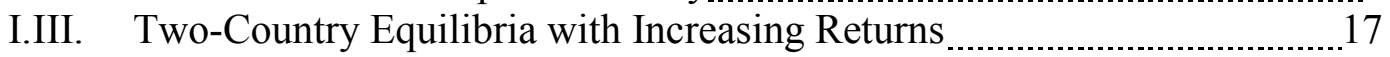

I.IV. A Simulation

I.V. Conclusions $\quad 30$

II. INCREASING RETURNS, COLLATERAL,

AND SOVEREIGN DEBT

II.I. Introduction $\ldots \ldots \ldots \ldots \ldots \ldots$

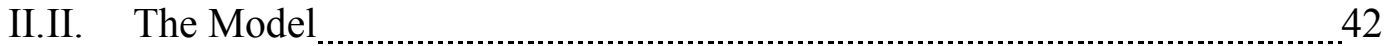

II.III. The Equilibrium Debt Contract $\ldots$

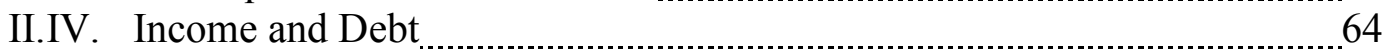

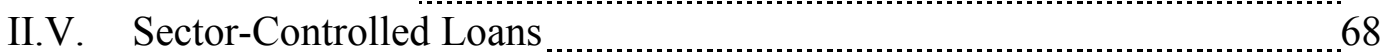

II.VI. Conclusions

III. INCREASING RETURNS, INSTITUTIONS, AND CAPITAL FLOWS

III.I. Introduction

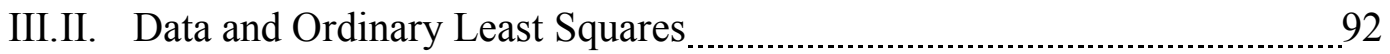

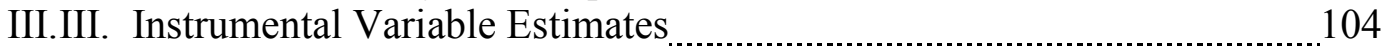

III.IV. Summary and Conclusions

LIST OF REFERENCES

APPENDICES $\ldots \ldots \ldots$

VITA 


\section{LIST OF TABLES}

TABLE

PAGE

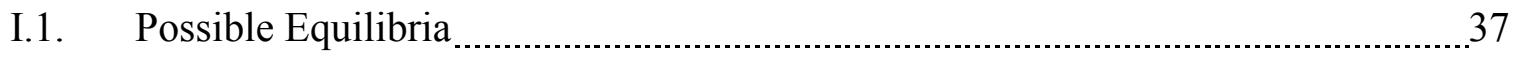

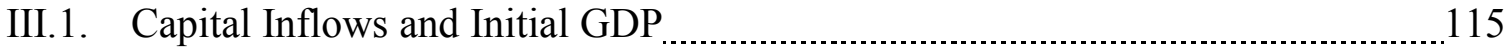

III.2. Determinants of Capital Inflows (World Sample) _.............................................116

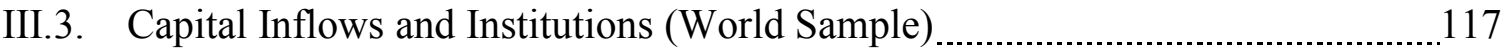

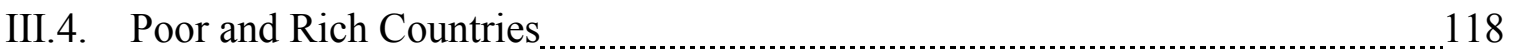

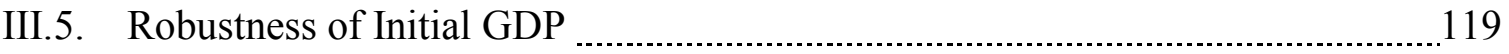

III.6. Testing for Validity of the Instrumental Variable

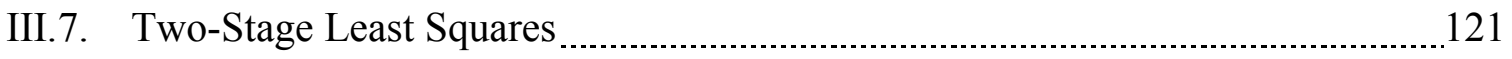

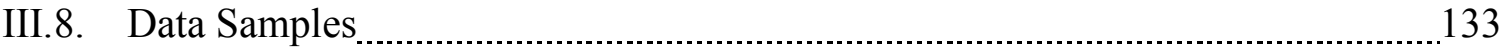




\section{LIST OF FIGURES}

FIGURE

PAGE

I.1. Marginal Returns to Investment

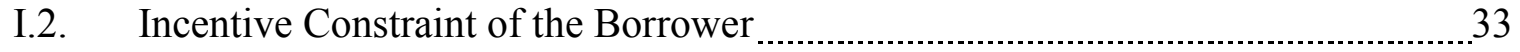

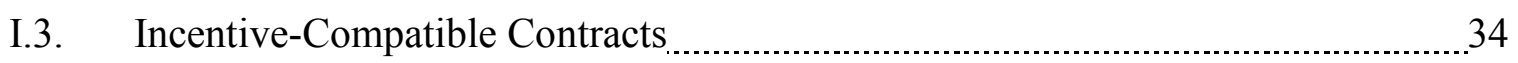

I.4. Two-Country Equilibria $\ldots \ldots \ldots$

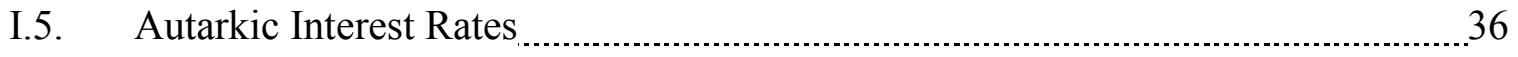

II.1. Production Function of the IRS and DRS Sector $\ldots$

II.2. Equilibrium Investment Composition given an Income and Debt Level _..............77

II.3a. Equilibrium Debt and Investment Composition Levels for a Sufficiently Poor Country

II.3b. Equilibrium Debt and Investment Composition Levels for a Sufficiently Poor Country

II.4a. Equilibrium Debt and Investment Composition Levels for a Threshold Income Level

II.4b. Equilibrium Debt and Investment Composition Levels for a

Threshold Income Level

II.5a. Equilibrium Debt and Investment Composition Levels for a Sufficiently High Income Level.

II.5b. Equilibrium Debt and Investment Composition Levels for a Sufficiently High Income Level.

II.6a. Equilibrium Debt and Investment Composition Levels for a Poor Country under Collateral Differences across Sectors

II.6b. Equilibrium Debt and Investment Composition Levels for a Poor Country under Collateral Differences across Sectors

II.7a. Equilibrium Debt and Investment Composition Levels for a Threshold Country under Collateral Differences across Sectors 
II.7b. Equilibrium Debt and Investment Composition Levels for a Threshold Country under Collateral Differences across Sectors

II.8. Equilibrium Debt after an Increase in Punishment in the Decreasing-Returns Sector

II.9. Income and Debt when Decreasing-Returns Sector is more Collateralized 84

II.10. Investment Composition with the Equilibrium Debt Level under Sector-Controlled Loans 85

II.11a. Optimal Debt for the Borrower when the Lenders can Control the Sector where the Loans are Invested

II.11b. Optimal Investment for the Lenders when they can Control the Sector where the Loans are Invested 86

III.1. Capital Inflows and Initial GDP. 109

III.2a. Capital Inflows and Initial GDP $(<2500)$ 110

III.2b. Capital Inflows and Initial GDP (>2500) 111

III.3. Poor and Rich Countries 112

III.4a. Capital Inflows and Initial GDP, Controlling for Institutions 113

III.4b. Capital Inflows and Institutions, Controlling for Initial GDP 114 


\section{INTERNATIONAL LENDING WITH INCREASING RETURNS AND MORAL HAZARD}

\section{I.I. Introduction}

Increasing returns to capital continues to be an active research area given the empirical support it has garnered in recent studies. It is interesting to note, for example, that the 2008 World Development Report, when referring to agriculture emphasizes the importance of increasing returns. Thus, we read that although "many international and national investments in $R \& D$ have paid off handsomely, with an average internal rate of return of 43 percent in $700 \mathrm{R} \& \mathrm{D}$ projects evaluated in developing countries in all regions," in Sub-Saharan Africa investment was considerably lower in part because the "small size of many of these countries prevents them from capturing economies of scale in agricultural R\&D ... For these countries, sharply increased investment and regional cooperation in R\&D are urgent" (p. 14-15). The evidence, such as the above example, also suggests that with increasing returns, there are low returns at low levels of investment.

Further, previous studies have suggested that there are increasing returns to infrastructure and manufacturing. Rodriguez (2008) finds evidence of increasing returns to manufacturing across nations. The empirical work on infrastructure and IT in the U.S. by Duggal, Saltzman, and Klein (1999, 2007) supports initial increasing returns. Fingleton and McCombie (1998) find evidence of increasing returns in EU manufacturing. Oliveira, Jayme, Jr., and Lemos (2006) find evidence of increasing returns in manufacturing in Brazil, and Park and Kwon (1995) find support for economies of scale in Korean manufacturing. 
The literature on the effects of increasing returns to scale is vast, including a large literature on poverty traps. Rosenstein-Rodan (1943) popularized the idea that a "big push" was necessary for some countries to take advantage of economies of scale. Many theoretical studies have shown since how a big push or collaborative effort is needed to move out of an equilibrium with low growth rates. For instance, Murphy, Shleifer, and Vishney (1989) and Azariadis and Stachurski (2004) provide an extensive analysis of these poverty traps. However, empirical tests of poverty traps have not substantiated the theory. Comparing the poorest quintile to the richest quintile of countries, Easterly (2006) finds that most poverty trap hypotheses are not robustly supported by the data. Rodriquez (2008) finds increasing returns to manufacturing, but does not find robust evidence for multiple equilibria. Although the evidence is debatable whether a big push of funds increases income per capita, the general belief is that a big push is necessary for some economies to get out of poverty traps. As described in Easterly (2006), 2005 was "the Year of the Big Push," as there was an international effort to meet the eight Millennium Development Goals for improvements in social and economic indicators in developing countries by the year 2015, which has led to an emphasis on foreign aid.

Despite all this literature on increasing returns, studies of its effects on international lending and borrowing are conspicuous by their absence. Studies have tended to focus on explaining why we might see increasing returns, such as human capital differences or institutional quality, but not many have actually modeled the effects of increasing returns on lending and borrowing. In one exception, Spiegel (1995) introduces increasing returns in a sovereign debt model and finds that the equilibrium credit constraint as a share of the capital stock is increasing in the capital stock, and 
increasing returns enhances the potential for long-term lending strategies. The setup in this paper differs from Spiegel in several aspects, asymmetric information and uncertainty is introduced, and the focus is on equilibrium investment levels, perverse capital flows, and equilibrium interest rates. Here, increasing returns to capital yield thresholds along with the possibility of multiple equilibria, which is consistent with the increasing-returns literature.

Introducing asymmetric information between the lender and borrower, along with the possibility of capital flight, gives rise to a moral hazard problem. The issue of moral hazard has been discussed extensively in the literature on international lending and borrowing, and especially in regards to the IMF (Atkeson, 1991; Corsetti, Guimaraes, and Roubini, 2006; Gertler \& Rogoff, 1990; Lane, 1999). Most of this literature, however, unlike the present paper, restricts attention to an environment with constant returns.

This paper models international lending and borrowing with increasing marginal returns to capital, in a setup characterized by the presence of moral hazard. I show how this environment can give rise to thresholds, multiple equilibria, perverse international capital flows, and interest rates that lie outside the interval of autarky rates. A small country set-up and a two-country case are examined. Asymmetric information and the possibility of capital flight, which create inefficient investment, are incorporated in the analysis. The model extends that of Gertler and Rogoff (1990), which only examines the case of diminishing marginal returns.

This paper is organized as follows. In section II., I set up the model for a small open economy. I find that introducing increasing returns to investment, combined with the problem of moral hazard, helps to further explain why there might be suboptimal 
borrowing or lending. In section III., I set up a two-country model and find that increasing returns may yield multiple equilibria and help explain why we could see capital flows from the poor to the rich country. In fact, contrary to statements in Gertler and Rogoff (1990), I show that under diminishing returns, funds must flow from the poor to the rich country as the capital account is liberalized. In section IV., I simulate the twocountry model to help illustrate the results. ${ }^{1}$ I also show how introducing initial increasing returns with free international capital mobility can lead to equilibrium interest rates that lie outside the interval of autarky interest rates. This stands in contrast to the standard result with diminishing returns, where equilibrium interest rates under capital mobility lie between the autarky levels. Section V. concludes.

\section{I.II. Model for a Small Open Economy}

To see the effects of increasing returns to scale on borrowing and lending, I use the model introduced in Gertler and Rogoff $(1990) .{ }^{2}$ I first look at a small country that faces the gross world interest rate $R^{W}$ (or $1+r^{W}$, where $r^{W}$ is the net interest rate). I assume that the country is populated by entrepreneurs who live for two periods. They invest in period 1 and consume only in period 2. This allows us to focus on the investment story and abstract from the effects of consumption smoothing, without losing any major insights. I assume the representative entrepreneur is risk neutral with the linear utility function:

$$
U\left(C_{1}, C_{2}\right)=C_{2}
$$

\footnotetext{
${ }^{1}$ For a good discussion on why computations are useful, see Judd (1997)

${ }^{2}$ I use a slightly simpler version from the textbook of Obstfeld and Rogoff (1996).
} 
In the first period, the entrepreneur receives an exogenous endowment of $Y_{1}$, which can be either invested abroad at the world riskless interest rate $R^{W}$ or invested in a risky domestic firm. Investment in the domestic firm at level $I$ yields an output $Y_{2}$ distributed as follows:

$Y_{2}=\left\{\begin{array}{l}Z \text { with probability } \pi(I) \\ 0 \text { with probability } 1-\pi(I)\end{array}\right.$

I assume $\pi^{\prime}(I)>0$ for all levels of investment; however, unlike Gertler and Rogoff (1990), I assume $\pi^{\prime \prime}(I)>0$ for low levels of investment and $\pi^{\prime \prime}(I)<0$ for high levels of investment. I look at the case where initial levels of investment have increasing returns to scale. We should, however, eventually expect the marginal returns to be diminishing after some critical investment level. The main contribution of this paper is to analyze what are the implications that initial increasing returns to investment may have on international lending and borrowing with moral hazard. The assumption in this model is that the source of the increasing returns is internal to the firm, but alternatively one can view the returns as external and assume that the borrower is the government and social planner.

The entrepreneurs would like to maximize the present value of their expected return on their home investment minus the investment, i.e.,

$-I+\frac{\pi(I) Z}{R^{W}}$.

The first-order condition of this maximization problem is $\pi^{\prime}(I) Z=R^{W}$. 
For the case of diminishing returns to investment, some investment level $\bar{I}$ is the unique solution to the maximization problem. With initial increasing returns to investment, we can have two investment levels that satisfy the first-order condition, where the higher of those two levels achieves the maximum value from domestic investment. Note that in the diminishing-returns model it is assumed $\pi^{\prime}(0) Z>R^{W}$ to ensure that a positive level of investment is efficient under symmetric information. I assume that the initial returns are low $\pi^{\prime}(0) Z<R^{W}$, which may be more realistic, especially in big projects such as infrastructure, and which also explains why the poorest countries are not getting enough investment in such projects (such as the R\&D example mentioned earlier). A positive level of domestic investment can still be assured under symmetric information if the marginal returns eventually surpass the world rate enough to make up for the initial low returns.

Figure I.1. shows the expected marginal return on domestic investment, $\pi^{\prime}(I) Z$, and the return from investing in riskless world securities, $R^{W}$. I assume that $\pi^{\prime \prime}(I)>0$ for $I<\tilde{I}$ and $\pi^{\prime \prime}(I)<0$ for $I>\tilde{I}$, where I define the investment level labeled $\tilde{I}$ as the investment level where the marginal returns to domestic investment switch from increasing to decreasing. I also assume $\pi^{\prime}(\tilde{I}) Z>R^{W}$, to guarantee some investment levels in the domestic firms yield higher marginal rates of return than the world rate. While I placed the intercept for the domestic returns at the origin, a country with some infrastructure or industry buildup would have an intercept nearer to the world rate. The two investment levels $\underline{I}$ and $\bar{I}$ are where the expected return to domestic investment 
equals the riskless world return. As will be shown in the following sections, the efficient investment level will not be achieved under asymmetric information, and when combined with increasing returns, then little or no domestic investment may occur.

\section{Incentive Compatibility}

Before solving for the possible loan contracts, I must define the incentive constraints of the borrowers and lenders. Define $L$ as the amount of funds that the domestic entrepreneur may secretly lend abroad instead of at home, and $D$ as the amount of the loan to the domestic entrepreneur. I define the domestic individual's period one finance constraint as

$I+L=Y_{1}+D$

where

$L \geq 0$ and $D \geq 0$.

If foreign lenders are risk neutral and operate in a competitive market, they earn the expected return of $R^{W}$ on any loan to an entrepreneur. In the "bad" state of nature, where $Y_{2}=0$, no repayment would be possible by the entrepreneurs. Therefore, promised payments by the entrepreneurs have to be of the state-contingent form $P\left(Y_{2}\right)$, where $P(0)=0$ and $P(Z)$ is determined by the lender's zero profit condition: $\pi(I) P(Z)=R^{W}\left(I-Y_{1}\right)$

The zero profit condition states that the expected payment give the lenders a return of $R^{W}$ on their loan, given the entire amount of the loan is domestically invested by the entrepreneurs. As I will discuss later, in an equilibrium contract, we would expect that the amount of secret lending by the entrepreneurs, $L$, will be equal to zero. 
If domestic investment equals $\bar{I}$, this would be the first-best borrowing contract. In the case with initial increasing returns, $\bar{I}$ is the higher investment level which solves $\pi^{\prime}(I) Z=R^{W}$. If there is asymmetric information, the borrower is not able to commit credibly to an investment of $\bar{I}$. Alternatively, a lower investment level $\underline{I}$ also satisfies the first-order condition, but the borrower is making a lower marginal return than $R^{W}$ on all of the domestic investment below $\underline{I}$. Since the marginal returns begin low, but then exceed the world interest rate over some range of investment, domestic investment must be large enough in order for the total return to exceed the return from putting all the funds in the riskless world asset.

As in Gertler and Rogoff (1990), I assume the following information structure: The borrower's first-period endowment $Y_{1}$, gross borrowing $D$, and second-period output $Y_{2}$, are directly observed by the lender. However, the lender does not directly observe the first-period investment, $I$, or the amount of funds, $L$, that the entrepreneur may secretly lend abroad in period 1 . The borrowers do not choose $I$ and $L$ until the lenders set the amount and terms of the loan, $D$ and $P\left(Y_{2}\right)$. If the "bad" outcome occurs, the lender cannot prove that the borrower did not use the entire amount of the loan for domestic investment.

Given the state-contingent payment plan and the possibility of secretly acquiring foreign assets, the borrowers will try to maximize expected second-period consumption:

$$
\begin{aligned}
E C_{2} & =\pi(I)[Z-P(Z)]+[1-\pi(I)][0-P(0)]+R^{W} L \\
& =\pi(I)[Z-P(Z)]-[1-\pi(I)] P(0)+R^{W}\left(Y_{1}+D-I\right) .
\end{aligned}
$$


The first-order condition for an interior maximum with diminishing returns is given by $\pi^{\prime}(I)[Z-P(Z)+P(0)]=R^{W}$.

Note that if the debt payments were the same in both the good and the bad state, there would be no moral hazard problem since the borrowers would have the incentive of choosing the efficient level of investment, which satisfies $\pi^{\prime}(I) Z=R^{W}$. However, since the "bad" state yields nothing, the borrowers cannot repay, so we set $P(0)=0$. Recall that the optimal contract under commitment is $P(Z)=\frac{R^{W}\left(\bar{I}-Y_{1}\right)}{\pi(\bar{I})}$, which is positive if $Y_{1}<\bar{I}$. Since expected repayment is positive at the efficient level of investment, the marginal return $\pi^{\prime}(I) Z$ must be must be higher than the world rate $R^{W}$ in order for the borrower to get a net marginal return of at least $R^{W}$. Therefore, if offered a loan to invest the efficient amount, the borrower will instead choose to invest some amount less than the efficient investment level $\bar{I}$ in the domestic economy. The intuition is that the lender agrees to share the risk of a bad outcome whenever $P(Z)$ is different from $P(0)$, and the borrower has less incentive to invest in the good outcome and secretly lends some money abroad to earn the sure return $R^{W}$.

Under increasing returns to investment, there can be two investment levels for a given expected repayment that sets the net marginal return to the borrowers equal to the world interest rate. If investment happened to be at the point where the net marginal return equals the riskless interest rate, then the borrower will be indifferent between investing domestically and lending at the world rate. However, in this setup the borrower determines how much to invest, and if the repayment is low enough to give the borrower 
a net marginal return equal to the world rate, the repayment may still be too high to give the borrower a net total return that would exceed what the borrower could have made lending everything at the world rate. Since the marginal domestic product starts low, $\pi^{\prime}(0) Z<R^{W}$, in order for the borrower to be willing to invest the funds domestically, there must be a sufficient range and magnitude at which the expected net marginal returns exceed the world rate, $\pi^{\prime}(I)[Z-P(Z)]>R^{W}$, to get an expected net return from investing domestically that is higher than investing everything at the world rate, $\pi(I)[Z-P(Z)] \geq I R^{W}$.

Assuming the domestic marginal returns do sufficiently exceed the world rate enough such that there exists a positive repayment amount that the borrowers would be willing to accept, there is no guarantee that such a repayment would be acceptable to the lenders. Sufficiently poor countries may not be able to contract for funds since the repayment required by the lenders in the good state may be too large to meet the condition in equation 8. If the borrower's income is large enough, we can solve for contracts that are compatible with both the incentives of the borrower and the lender, which is done in the next section.

\section{Equilibrium Incentive-Compatible Contracts}

I can now solve for the possible incentive-compatible contracts, where both the borrowers and the lenders expect to earn a return that will give them at least the riskless return, $R^{W}$. From the borrower's first-order condition and equation 8 , we can write the incentive compatibility constraint as

$$
P(Z) \leq \operatorname{Min}\left[Z-\frac{R I}{\pi(I)}, Z-\frac{R}{\pi^{\prime}(I)}\right]
$$


The incentive constraint says that the expected repayment cannot be too high such that the borrower could have made a higher return from secretly lending at the world rate, nor can the repayment be too high such that the net marginal return is lower than the riskless world asset. Unlike the model with diminishing returns to investment, as explained below, we have an incentive compatibility constraint that is increasing for low levels of investment and decreasing for higher levels of investment. Graphically, this is shown in Figure I.2., where IC(1) is the first condition that must be satisfied in the incentive constraint, while $\mathrm{IC}(2)$ is the second. The portion that satisfies both conditions is the incentive constraint.

If the domestic marginal product starts out lower than the riskless world rate at low investment levels, then the borrower will invest domestically only when it can invest enough funds to get a sufficient amount of higher marginal returns to be worth it. The borrower's incentive constraint will intersect the horizontal axis in Figure I.2. when the expected domestic output equals the total riskless return, $\pi(I) Z=I R^{W}$, since the borrower will not agree to any positive repayment for any investment lower than this level under increasing returns. Once the expected domestic output exceeds the total return from investing in the riskless asset, the risk-neutral borrower would be willing to make a positive repayment. Therefore, the slope of the incentive constraint is initially positive.

The expected repayment acceptable to borrowers, $\pi(I) P(Z)$, will increase as long as the gap between the expected output, $\pi(I) Z$, and the return on the riskless asset, $I R^{W}$, increases. This gap will be at its largest when the marginal domestic return equals 
the world interest rate (the higher $I$ that solves the equation), $\pi^{\prime}(I) Z=R^{W}$. The acceptable contracted repayment to the borrowers in the good state, $P(Z)$, will increase as long as the net marginal return, $\pi^{\prime}(I)[Z-P(Z)]$, exceeds the world rate $R^{W}$. Solving the first condition of the borrower's incentive constraint in equation (9), $Z-\frac{R^{W} I}{\pi(I)}$, for a maximum, we would find that the acceptable repayment is highest when $I=\frac{\pi(I)}{\pi^{\prime}(I)}$. At this investment level, $P(Z)=Z-\frac{R^{W}}{\pi^{\prime}(I)}$, which is the second incentive constraint condition, where the expected net marginal return equals the world interest rate. For investment levels above this level, the borrower's incentive constraint is now the second condition in equation (9).

While some higher repayment than specified in the second condition of the incentive constraint may still give the borrower a higher net total return than lending at the world rate, the borrower will not repay such an amount that would make the net marginal return on domestic investment less than the risk-free interest rate. This second condition of the incentive constraint is increasing under increasing returns and decreasing under diminishing returns. If the borrower can invest enough domestically such that the repayment is lower in the second condition, it must be the case that there is decreasing returns to scale. The expected net total return can be thought of as the average return given a repayment, which will only catch up to the marginal return if the marginal return declines. 
Intuitively, the second condition of the incentive constraint in Figure I.2. intersects the horizontal axis at $\underline{I}$ and $\bar{I}$. Any domestic investment level below $\underline{I}$ or above $\bar{I}$ will provide a marginal return less than the return in the world market, so no repayment would be acceptable for a borrower. The first condition of the incentive constraint, IC(1), intersects the horizontal axis when the expected output equals the expected return that could be made from investing everything in at the riskless rate, $\pi(I) Z=R I$. The first intercept of IC(1) comes at a higher investment level than the first intercept of IC(2) since the total return from investing in the domestic economy will not exceed the amount that could be made from lending everything at the world rate until the domestic marginal returns have sufficiently exceeded the world interest rate. The second horizontal intercept of IC(1) comes at higher investment level than the second intercept of IC(2) since the borrower may still expect an overall positive return even if for some range of investment the marginal return did not exceed the riskless world rate.

In Figure I.3., the incentive constraints of the borrower and lender are drawn. The zero-profit condition of the lenders, $P(Z)=\frac{R^{W}\left(I-Y_{1}\right)}{\pi(I)}$, intersects the horizontal axis at $I=Y_{1}$. If investment equals the endowment income in equilibrium, then there is no borrowing or lending, so there would be no repayment. Once investment is greater than the endowment, we would see some positive amount of repayment necessary for the zeroprofit condition to hold. As debt initially grows, the amount of the repayment must increase since the lender must get repaid some positive amount in order to break even. Therefore, the slope of the zero-profit condition must initially be positive. Under 
diminishing returns, it can be shown that it will always have a positive slope. In Figure I.3., the zero-profit condition is drawn with a positive slope.

However, if there are some initial increasing returns, then the slope of the zeroprofit condition may actually be negative under some range of investment levels. If the marginal returns increase high enough, then it is possible that the additional debt increases the probability of the good state enough such that the repayment required to break even will decrease. To see this, if we calculate the first derivative from the zeroprofit condition, $\frac{\partial P(Z)}{\partial I}$, we can find that it will be positive if $\pi(I)>D \pi^{\prime}(I)$, which is not necessarily true under increasing returns to scale. What this means is that it is possible that an increase in loans to the borrower may actually decrease their real debt since the borrowers can be allowed to repay less because of the decrease in uncertainty that the investment will be successful.

In addition, given the slope of the borrower's incentive constraint, even without a dip in the zero profit condition, it is possible that the borrower may not be willing to agree to repay an acceptable amount to the lenders at some low amount of debt, but at a higher level of debt the borrowers and lenders may achieve an incentive-compatible contract. This case is shown in Figure I.3. While a dip in the zero-profit condition is possible if we assume the income is low enough, there is no guarantee given such parameters that the zero-profit condition will ever allow for a repayment that is low enough for the borrowers to accept. With a sufficiently high income, a contract may be possible between the borrower and lenders, but the zero-profit condition may not have any negative slope if it starts at an income level where the increasing returns are 
exhausted. In Figure I.3., the zero-profit condition is drawn given a sufficiently high income where there is no range at which the slope is negative.

In Figure I.3., the endowment income of the borrower (where ZP equals zero) is not sufficient to make domestic investment worthwhile (where IC equals zero) without any loans. For a small amount a debt, the borrower would still not invest domestically, which would create the bad domestic outcome and no repayment. For a large enough debt, such that investment can reach the borrower's incentive constraint, the borrower would be willing to invest domestically if the promised repayment in the good outcome is low enough. The lenders will agree to the contract if the expected repayment, $\pi(I) P(Z)$, gives them at least the riskless rate. In Figure I.3., the borrower and lender can agree on a loan that leads to investment between $\underline{I}^{*}$ and $\bar{I}^{*}$. The largest loan possible in this example is one that leads to the investment level of $\bar{I}^{*}$, which will be the equilibrium under no other constraints.

In the example in Figure I.3., the only feasible contracts are where the zero-profit condition of the lenders meet the first condition of the incentive constraint of the borrowers (see IC(1) in Figure I.2.). This says that in equilibrium, the borrowers are investing domestically and getting marginal product that is not only higher than the world interest rate, but if the repayment is included, the net marginal return is still higher than the riskless interest rate. This possible result differs than what can happen if only diminishing returns were assumed (and higher initial returns), where the borrowers would only be concerned about the net marginal return on the additional investment and not the expected net overall return from the investment. Where investment equals $\bar{I}^{*}$, 
repayment that sets the net marginal return equal to the world interest rate would be at a higher repayment than the repayment on the incentive constraint in Figure I.3., which can be seen in IC(2) in Figure I.2.. If investment was at $\bar{I}^{*}$, then the borrowers would be willing to accept a higher repayment at the margin, but since the borrowers do not have to invest anything domestically, they would not accept any repayment that would on average give them a lower net return than what they could have made lending at the world rate. For investment above $\bar{I}^{*}$, the repayment that the lenders need in order to break even exceeds the amount that the borrower would be willing to make, even though the amount that the borrower would be willing to repay increases. Therefore, with initial increasing returns, a sufficiently poor country may get less debt, invest less, and have a higher domestic marginal product than compared to the case with only diminishing returns.

A larger endowment income may shift the ZP curve to where it only intersects the IC curve on the IC(2) portion. In this case, the borrower will accept a repayment that sets the net marginal return equal to the world interest rate. A higher repayment may still give the borrower an expected positive net overall return, but the borrower could benefit more by secretly lending any funds that allow for investment to exceed the point where the net marginal return equal the riskless rate. The lenders, therefore, would not be willing to lend any amount above the point where the two curves intersect. This result is similar to the case where only diminishing returns to scale is assumed. If the endowment income is much smaller than the example in Figure I.3., then the lenders and borrowers cannot agree on any loan amount. This differs from the diminishing returns case, where 
initial returns are high and there will always be some amount that the two parties could agree on.

We can also see that in an equilibrium that yields a contract, the borrowers will not secretly lend any amount at the world rate. As long as the contract is incentivecompatible for both the lenders and borrowers, there will be no capital flight. If the borrower chose to secretly lend abroad, then it must mean that the promised repayment in the good state was too high to invest all the loans domestically. This would mean that the repayment and investment schedule was not on the incentive constraint of the borrower, and hence not an equilibrium contract.

\section{I.III. Two-Country Equilibria with Increasing Returns}

In this section, I will setup the two-country model as in Gertler and Rogoff (1990), but I will introduce initial increasing returns to scale. We will see how introducing increasing returns to scale can further explain the possibility of capital flows from the poor country to the rich country. In fact, I will show how capital must flow from the rich country to the poor country under diminishing returns as we go from autarky to free international capital flows in this model. With increasing returns to scale, we may observe capital flowing from the poor country to the rich country, as in capital flight from the Southern cone.

Assume two countries, Rich and Poor, have equal populations. In each country, a fraction $s$ of the population are savers, and 1-s are entrepreneurs. The savers can diversify their portfolio and assure themselves of a riskless return of $R$, which I will solve for in this section. In the Rich country, both entrepreneurs and savers have an endowment of $y_{1}^{r}$, while in the Poor country they have an endowment of $y_{1}^{p}$. Both 
countries have identical preferences and technologies. I assume that individuals in the Rich country have a higher endowment, $y_{1}^{r}>y_{1}^{p}$. As in the small country case, I define the utility function as $U\left(C_{1}, C_{2}\right)=C_{2}$, so all of the first-period income will be invested.

If there were no asymmetric information, then we would expect the investment levels in the Rich and the Poor countries to be governed by the first-order conditions, $\pi^{\prime}\left(I^{r}\right) Z=R^{r}$ and $\pi^{\prime}\left(I^{p}\right) Z=R^{p}$. Under full information we would have the optimal level of investment for both countries, $\bar{I}^{r}=\bar{I}^{p}$. The world interest rate would then be equal the common expected marginal product of capital,

$\pi^{\prime}\left(\bar{I}^{r}\right) Z=\pi^{\prime}\left(\bar{I}^{p}\right) Z=\pi^{\prime}\left[\frac{y_{1}^{r}+y_{1}^{p}}{2(1-s)}\right] Z$

where the investment levels are per entrepreneur. Intuitively, if the income will flow to the country yielding the highest rate of return, and the countries' have the same technology with eventual diminishing returns, then we would expect half of the world income to be invested by entrepreneurs in one country and the other half to be invested by the entrepreneurs in the other country.

Under the full-information case with only diminishing returns, savings cannot flow from the Poor country to the Rich country as we go from autarky to free international capital flows. If savings did flow from the Poor country to the Rich country, then it must have meant that the Poor country had a lower marginal product under autarky. However, this means that the initial endowment of the Poor country per entrepreneur must have been greater than the efficient level of investment per entrepreneur, or $\frac{y^{p}}{1-s}>\frac{y^{p}+y^{r}}{2(1-s)}$. This inequality simplifies to $y^{p}>y^{r}$, which is a 
contradiction. In the efficient outcome under full information and diminishing returns, savings must flow from the Rich to the Poor country.

However, the efficient outcome will be distorted when I introduce moral hazard with state-contingent repayment plans that have different values for the different states. We would then expect a poor country that has to borrow more to reach $\bar{I}$ would have a more severe moral hazard problem than a rich country, given that it has to pay more in the good outcome, and it would be given a contract that yields less investment than a rich country. By introducing initial increasing returns, we will see that this inefficiency can be worse. With increasing returns, the moral hazard problem could create an even bigger investment gap between the Poor and the Rich country than if there were only diminishing returns. When entrepreneurs of the rich country have the advantage of not having to borrow as much (or pay back as much) as the entrepreneurs of a poor country for a given level of investment, the rich country has a less severe moral hazard problem since the difference in repayment in the two states of nature is not as great. The rich country can then contract for more funds that leads to more investment, and with increasing returns get a higher rate of return, which leads to even more funds and investment and a greater gap in investment levels between the two countries.

As in Gertler and Rogoff (1990), I will assume both $y_{1}^{r}<\bar{I}^{r}$ and $y_{1}^{p}<\bar{I}^{p}$ in equilibrium, so entrepreneurs in both countries must be financed by the savers to achieve the first-best equilibrium. In this two-country general equilibrium model, all the income will be invested. The question of this section is how the income will be distributed between the two countries, and how will the introduction of initial increasing returns to 
scale can affect the investment gap between the two countries. I will now set up the twocountry model and show that introducing increasing returns can explain the possibility of savings flowing from the poorer to the richer country.

As in the small-country case, under asymmetric information, the contracts that are offered to the entrepreneurs must satisfy their incentive-compatibility constraints. In this two-country setup, where the world rate is endogenous, the borrowers are concerned with the incentive constraints

$$
P(Z)^{r}=Z-\frac{R^{r}}{\pi^{\prime}\left(I^{r}\right)} \text { and } P(Z)^{p}=Z-\frac{R^{p}}{\pi^{\prime}\left(I^{p}\right)},
$$

which is IC(2) in the small country case. The first condition of the incentive constraint in the small country case is not applicable here since the world rate is endogenous and cannot be taken as given when considering the total investment. As in the small country case, the lenders face the zero-profit conditions

$$
P(Z)^{r}=\frac{R^{r}\left(I-y_{1}^{r}\right)}{\pi\left(I^{r}\right)} \text { and } P(Z)^{p}=\frac{R^{p}\left(I^{p}-y_{1}^{p}\right)}{\pi\left(I^{p}\right)}
$$

I can solve for $R$ by setting the borrower's incentive constraint and the lender's zeroprofit condition equal to each other. For the Rich country (and a parallel solution for the Poor) we have,

$$
R^{r}=\frac{\pi^{\prime}\left(I^{r}\right) Z}{1+\frac{\pi^{\prime}\left(I^{r}\right)\left(I^{r}-y_{1}^{r}\right)}{\pi\left(I^{r}\right)}}
$$

This is the same equation as in Gertler and Rogoff (1990); however, with the introduction of increasing returns to investment, we could get different possible outcomes in regards to the equilibrium investment level. 
Graphically, the investment levels which yield the same returns from the two countries are shown in Figure I.4. The curves labeled $R^{r}=R^{p}$ are investment levels where the risk-free interest rate for the Poor and the Rich country are equal. The IS curve, with a slope of negative one, is where all the income is invested. Point $\mathbf{C}$ is the efficient point, where $I^{r}=I^{p}$. An equilibrium where investment is occurring in both countries will be where the interest rates were equal. If the interest rates were not equal, then we would expect savings to flow to the country with the higher interest rate.

We see from Figure I.4. that we have two separate curves that show where the interest rates are equalized between the countries, $R^{r}=R^{p}$. With initial increasing returns and then decreasing returns, high levels of investment by the Rich country can give a return that is the same as low levels of investment by the Poor country, and vice versa. Given the two curves, we have three possible interior equilibria, points $\mathbf{A}, \mathbf{B}$, and D. These points are where all the income is invested and where both countries have the same interest rate. As will be clear below, the more interesting $R^{r}=R^{p}$ curve is the upper one for investment levels $I^{r}, I^{p}>y_{1}^{p}$, and the more plausible equilibrium in our setup is at point $\mathbf{B}$.

When the entrepreneurs in both countries can finance their investment without relying on the savers, we should expect the rate of return for the Rich country to be equal to the Poor country for a given investment level. Since there is no repayment required when $I<y_{1}$, the expected return to investment in each country would simply be $\pi^{\prime}(I) Z$. Therefore, we have $R^{r}=R^{p}$ at $I^{r}=I^{p}$ when $I^{r}, I^{p} \leq y_{1}^{p}$. Now focusing on the upper $R^{r}=R^{p}$ curve, when investment levels are above the income of the entrepreneurs of the 
Poor country, the Rich country will have a higher net expected rate of return for each given investment level. The Poor country has a lower net expected rate of return because of the repayment they must make in the good state of nature, and the corresponding interest rate will be lower in autarky in the Poor country. The equilibrium interest rate sets the repayment equal between the borrower and lender as in equation 11. Looking at the $R^{r}=R^{p}$ curves in Figure I.3., we would expect to see a jump from the lower curve to the higher curve as investment levels surpass $y_{1}^{p}$. When investment levels initially surpass $y_{1}^{p}$, the entrepreneurs of the Poor country must borrow money to invest, and this will result in a relatively lower net expected rate of return since they now must repay the lenders. So for the investment levels, $y_{1}^{p} \leq I<y_{1}^{r}$, we are comparing an expected rate of return of $\pi^{\prime}\left(I^{p}\right) Z$ for the entrepreneurs in the Rich country and $\frac{\pi^{\prime}\left(I^{p}\right) Z}{1+\frac{\pi^{\prime}\left(I^{p}\right)\left(I^{p}-y_{1}^{p}\right)}{\pi\left(I^{p}\right)}}$ for the entrepreneurs of the Poor country.

As investment surpasses $y_{1}^{H}$ for the Rich country, the entrepreneurs have to start borrowing and the expected riskless rate of return for the Rich country is $R^{r}=\frac{\pi^{\prime}\left(I^{r}\right) Z}{1+\frac{\pi^{\prime}\left(I^{r}\right)\left(I^{r}-y_{1}^{r}\right)}{\pi\left(I^{r}\right)}}$. In order for the expected rate of return for the Rich country to equal the expected rate of return for the Poor country at $I^{p}=y_{1}^{p}$, the returns should fall in the Rich country. If the returns are increasing at $I^{p}=y_{1}^{p}$, then there could be a large investment gap between the two countries by the time the rate of return of the Rich country returns to the level it was at when $I^{r}=I^{p}=y_{1}^{p}$. This is the gap between the two 
$R^{r}=R^{p}$ curves at $I^{p}=y_{1}^{p}$. On the other hand, if there were diminishing returns from the start, then there would be no discontinuity, simply a gradual continuous increase in the difference of the investment levels along a single $R^{r}=R^{p}$ curve in the range $y_{1}^{p} \leq I<y_{1}^{r}$.

Under increasing returns, as we look at investment levels for the Poor country above $y_{1}^{p}$, we would expect to see the investment gap between the two countries to decrease, which is represented by a dip in the upper $R^{r}=R^{p}$ curve. We should see the investment gap decrease because the rate of return for the Poor country is increasing and the rate of return for the Rich country is decreasing at the higher investment level, so a decline in $I^{r}$ would increase $R^{r}$ to match the increase in $R^{p}$ in the Poor country.

In Figure I.4., the IS line represents the point where investment equals savings, $\frac{y_{1}^{r}+y_{1}^{p}}{1-s}=I^{r}+I^{p}$. Since all income will be invested according to our utility function (1), the equilibrium should end up on that line. Because of the moral hazard problem, we would not end up at the efficient point $\mathbf{C}$, where the investments levels equal to each other (note: $\frac{\partial R}{\partial y_{1}}>0$ for a given level of investment, so for the same investment level the richer country would have a higher marginal return at the efficient point). Point $\mathbf{B}$ seems to be the equilibrium with the most intuitive appeal. As pointed out earlier, until $I>y_{1}^{p}$ , the relevant curve is the lower $R^{r}=R^{p}$. Then we jump to the upper curve until all the savings are invested. This would leave us at point $\mathbf{B}$. At this point, we see there is more investment in the richer country, and possibly savings are flowing from the poor country 
to the rich country. Points $\mathbf{A}$ and $\mathbf{D}$ are also possible equilibria since the returns are equal at those points, and all income is invested, but the mechanism at which we get to those levels is not as intuitive.

Increasing returns to investment may create a greater investment gap between countries compared to decreasing returns because of the jump from the lower to the upper $R^{r}=R^{p}$ curve at $I=y_{1}^{F}$. In fact, it is possible that no savers will acquire securities from the poor country if the jump on the upper $R^{r}=R^{p}$ curve reaches the IS curve. This would happen if all of the income was invested before the rate of return of the Rich country returned to the rate of return of the Poor country when $I^{r}=I^{p}=y_{1}^{p}$. This would depend on the specified probability function $\pi(I)$ and its marginal return $\pi^{\prime}(I)$. While diminishing returns results in an investment gap because of moral hazard, introducing initial increasing returns could create a larger gap and help further explain why we see a difference in investment levels between rich and poor countries.

Not only can increasing returns create a bigger gap in investment levels between the rich and poor countries, it can also lead to capital flows from the poor to the rich countries. With diminishing returns, we cannot have capital flows from the poor to the rich countries as we move from autarky to free international capital flows, and this is shown in the appendix.

\section{Equilibrium Interest rates}

We are now in position to show that introducing increasing returns can lead to equilibrium interest rates that lie outside the autarky levels for the Poor and Rich country. We would normally expect the equilibrium interest rate to lie within the interval between 
the autarky interest rates. To show that with increasing returns the equilibrium interest rate(s) can fall outside the interval between the autarky interest rates, it suffices simply to provide an example. I do this in section IV.

Under diminishing returns, the equilibrium interest rate with free international capital flows must lie in the interval between the two autarky interest rates. From equation 11 , we can find $\frac{\partial R}{\partial I}<0$. If one country has a higher $R$, savings will flow to that country, and it will lower $R$. I just showed in the previous section that under diminishing returns, the richer country will have a lower $R$. Therefore, under diminishing returns, as we go from autarky to free international capital flows, savings would flow from the rich to the poor country. The poorer country's interest rate would then decrease and the richer country's interest rate would increase until the rates were equal. Hence, it must be that in equilibrium the interest rate will lie between the autarky levels.

To see a clearer picture of the effects of introducing initial increasing returns to investment, we can look at a numerical example. In section IV, I will examine a simulation by specifying a probability function that satisfies all the assumptions and requirements stated in the beginning of this paper. I will then go through an example of the two-country model. I will then show how the equilibrium interest rates with free capital mobility and increasing returns can lie outside the autarky rates.

\section{I.IV. A Simulation}

\section{The Two-Country Case}

As a first step, I will specify a probability function $\pi(I)$ that has initial increasing returns and then decreasing returns, while always assuming $\pi^{\prime}(I)>0$. We should also at 
the same time give a value to the good state, $Z$, so we can get the rate of return for the entrepreneur. For simplicity, set $Z=2$. For ease of exposition, the relevant investment levels would then be in the range $0 \leq I \leq 2$, since the value $\mathrm{Z}$ is known, and no investment should exceed $Z$ (otherwise an entrepreneur would be willingly investing an amount with no possibility of a return higher than his investment). An example of a probability function that satisfies all the properties for the investment values $0 \leq I \leq 2$ is $\pi(I)=\frac{1}{\sqrt{2}} I^{\frac{1}{I}}$

To illustrate my results in the two-country general equilibrium, I can graph the rates of return for each country and see if it implies a graph similar to Figure I.4. To better understand where the graph in Figure I.4. comes from, I can decompose it by drawing three curves, $\pi^{\prime}(I) Z, \frac{\pi^{\prime}\left(I^{r}\right) Z}{1+\frac{\pi^{\prime}\left(I^{r}\right)\left(I^{r}-y_{1}^{r}\right)}{\pi\left(I^{r}\right)}}$, and $\frac{\pi^{\prime}\left(I^{p}\right) Z}{1+\frac{\pi^{\prime}\left(I^{p}\right)\left(I^{p}-y_{1}^{p}\right)}{\pi\left(I^{p}\right)}}$. As stated earlier, when $I \leq y_{1}$, then the entrepreneurs are not borrowing any funds from the savers in order to finance their investment, so there is no repayment and the net return on investment is $\pi^{\prime}(I) Z$. Once $I \geq y_{1}$, the entrepreneurs have to borrow from the savers, which means the contracts must satisfy both the incentive constraints of the borrower and the zero-profit conditions of the lender. Therefore, we have $R=\frac{\pi^{\prime}(I) Z}{1+\frac{\pi^{\prime}(I)\left(I-y_{1}\right)}{\pi(I)}}$ in equilibrium for a country whose entrepreneurs must rely on the savers.

In Figure I.5., I graph the interest rates for each country, assuming the entrepreneurs in the Rich country have an income of $y_{1}=0.6$, while the entrepreneurs in 
the Poor country have an income of $y_{1}=0.3$. The interest rates of the two countries are the same for each investment level below 0.3, which is the income endowment of the Poor entrepreneurs. As investment surpasses 0.3 , we see that the Rich country has a higher rate of return than the Poor country. Savings would then flow towards the Rich country until the rate of return of the Rich country returns to the level of the Poor country.

In this example, the rate of return of the Rich country does not return to the same level as the Poor country at $I=0.3$ until investment in the Rich country reaches 1.28 per entrepreneur. This explains the jump that I explained in Figure I.4. from the lower to the upper $R^{r}=R^{p}$ curve. As investment in the Poor country initially increases from 0.3 , we see that the interest rate goes up, and an equivalent interest rate for the Rich country would be accompanied by an investment level of a little less than 1.28. This is why we see a small dip in Rich investment in Figure I.4. after the jump to the upper $R^{r}=R^{p}$ curve. Also, as the Poor increases investment from 0.3 , the higher interest rate of the Poor country can be achieved by lower investment levels of the Rich country, which explains the lower $R^{r}=R^{p}$ curve in Figure I.4. Eventually, the investment gap for a given interest rate starts to converge because of decreasing returns to investment. In equilibrium we are looking at where all the income is invested, and where the risk-free interest rates are equal (if an interior solution). The IS curve in Figure I.4. depends on the amount of savers and entrepreneurs.

By introducing increasing returns to scale, we see by the jump in Figure I.4., or by the large gap in Figure I.5., that it could potentially produce an even larger difference in 
investment than if we only assumed decreasing returns to scale. We see in Figure I.5. that introducing increasing returns to scale creates an initial larger advantage for the Rich country than if we just assumed decreasing returns to scale. And as I explained earlier, savings can flow from the Poor to the Rich country.

\section{Equilibrium Interest Rates with Increasing Returns}

I can show by example that the equilibrium interest rate with free international capital flows can lie outside the interval between the autarky interest rates. Using the same setting as before, I will assume that the individuals in the Rich country have an income of 0.6 , while the individuals in the Poor country have an income of 0.3 . I will also set the proportion of savers to be 0.42 . We can now calculate autarky investment per entrepreneur, $\frac{y_{1}}{1-S}$, for the Rich country, $I_{A}^{r}=1.034$, and the Poor country, $I_{A}^{p}=.517$.

We can now solve for the autarky risk-free interest rate by plugging the autarky investment levels into the equation $R_{A}=\frac{\pi^{\prime}(I) Z}{1+\frac{\pi^{\prime}(I)\left(I-y_{1}\right)}{\pi(I)}}$. For the rich country we get $R_{A}^{r}=0.948$ and for the poor country we get $R_{A}^{p}=1.104$. I explained earlier that for a given investment level, the rich country will have a higher interest rate, but here we have two different investment levels. Given that the rate of return on investment is initially increasing then decreasing, we could set the income levels and population parameters so that either the Rich or the Poor country has a higher risk-free interest rate in autarky.

Now we can find the equilibrium interest rates under free international capital

flows. In equilibrium, we must have $R^{r}=R^{p}$. Since we know the total world investment per entrepreneur is now $I_{A}^{r}+I_{A}^{p}=I^{W}=1.552$, we can find the equilibrium 
interest rates by setting $\frac{\pi^{\prime}\left(I^{r}\right) Z}{1+\frac{\pi^{\prime}\left(I^{r}\right)\left(I^{r}-y_{1}^{r}\right)}{\pi\left(I^{r}\right)}}=\frac{\pi^{\prime}\left(I^{W}-I^{r}\right) Z}{1+\frac{\pi^{\prime}\left(I^{W}-I^{r}\right)\left(I^{W}-I^{r}-y_{1}^{r}\right)}{\pi\left(I^{W}-I^{r}\right)}}$. Solving, I find that there are three possible equilibria, which is shown in Table I.1. In each of these possible equilibria, the riskless interest rate lies either above or below the interval between the autarky rates 0.948 and 1.104. Note that the efficient point, where $I^{r}=I^{p}=.776$, such as point $\mathbf{C}$ on Figure I.3., is not an equilibrium because at that point $R^{r}=1.554$ and $R^{p}=1.067$, which means savings would have an incentive to flow to the Rich country.

In the first equilibrium, we see that it corresponds to a point like $\mathbf{B}$ on Figure I.3. This seems to be the most intuitive equilibrium starting from an autarkic equilibrium. In this case, in autarky the interest rate for the Poor country is higher. Therefore, we would expect savings to flow to the Poor country from the Rich country with free capital mobility. Since the Poor country is experiencing increasing returns to scale in autarky, while the Rich country is experiencing decreasing returns, the flow of funds from the Rich to the Poor will increase the interest rate in both countries. In equilibrium, the interest rate can end up higher than the interest rates in autarky. The Poor country still does not obtain the efficient level of investment because of the moral hazard introduced in the model. The second and third possible equilibria correspond to points like $\mathbf{A}$ and $\mathbf{D}$ on Figure I.4. They are equilibria in a sense that all the income is invested and the interest rates are equal across countries. The transition from the autarky equilibrium to those points, however, is not as intuitive. 


\section{I.V. Conclusions}

The paper combined increasing returns to investment and moral hazard into an international lending and borrowing model. The paper gives us an alternative explanation regarding the phenomenon of inefficient investment in poorer countries. I expanded on the model introduced by Gertler and Rogoff (1990), where they showed how asymmetric information can lead to less investment in the poorer country. By introducing initial increasing returns, however, we see that we can have equilibrium investment levels much lower in the small-country model than with diminishing returns. In the two-country model, I demonstrated that increasing returns helps explain how we can get savings flows from the Poor to the Rich country, and the possibility of multiple equilibria. I also demonstrated that equilibrium interest rates can lie outside of autarkic levels after the capital account is liberalized.

The literature gives several reasons why we do not see capital flowing from the richer countries to the poorer countries. These include technology levels, human capital levels (Lucas 1990), institutions (Alfaro, Kalemli-Ozcan, and Volosovych 2005), and serial default (Reinhart and Rogoff 2004). In this paper, as in Gertler and Rogoff (1990), I assumed the same technology and enforceable contracts in the two-country model. The only difference between the countries in our two-country model was their income.

The implications of the results in the small country case is that a country may need at least some minimum amount of funds to take advantage of the increasing returns, but still too much funds can lead to a moral hazard problem. Initial increasing returns with free capital flows would not be a problem in this model if it were not for the asymmetric information. To prevent default (or capital flight in this model), a lender may 
need to both lend more to take advantage of increasing returns and setup a better mechanism to monitor the investment. Previous models ignore the minimum lending requirement.

Further research can focus on different sectors of the economy to determine the impact of increasing returns on sovereign debt. Some sectors may have large economies of scale while other sectors may not. With asymmetric information, poorer countries may struggle to get loans for sectors that have large economies of scale, and they may have to settle for investment in less productive sectors. A sovereign debt model may be extended to analyze this situation. 
Figure I.1. Marginal Returns to Investment

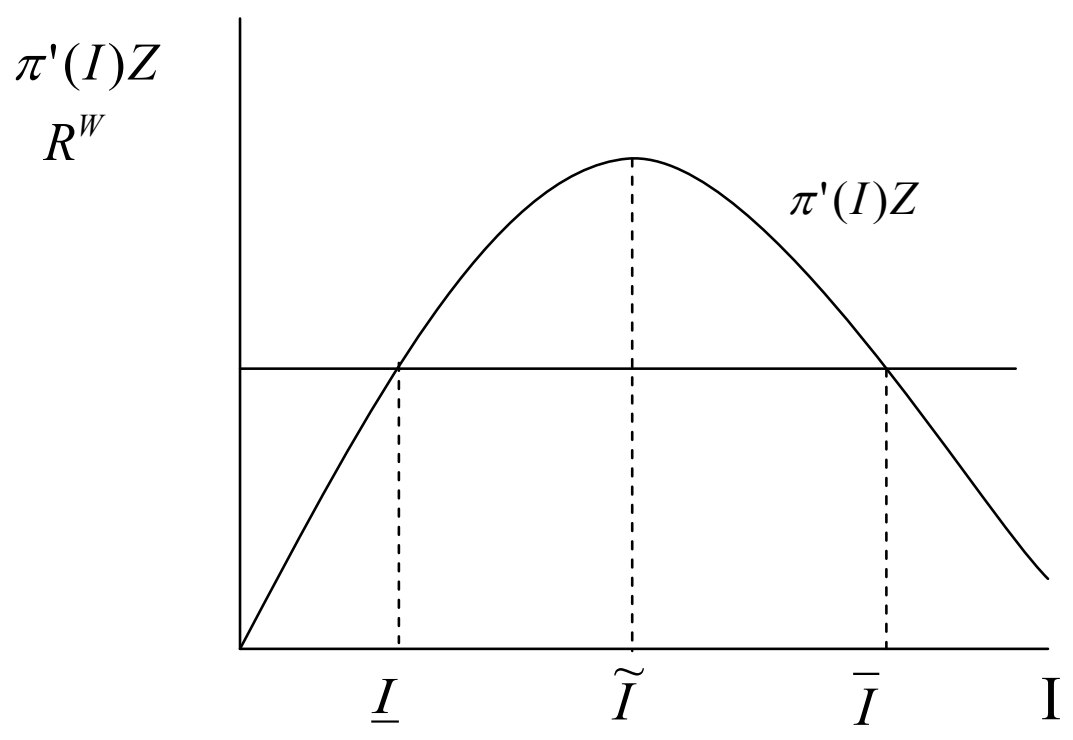

Notes: Figure I.1. shows the marginal return to investment in the domestic economy, $\pi^{\prime}(I) Z$, and the world interest rate. At low levels of investment, the marginal return in the domestic economy is low, but it increases and surpasses the world interest rate at higher levels of investment. 
Figure I.2. Incentive Constraint of the Borrower

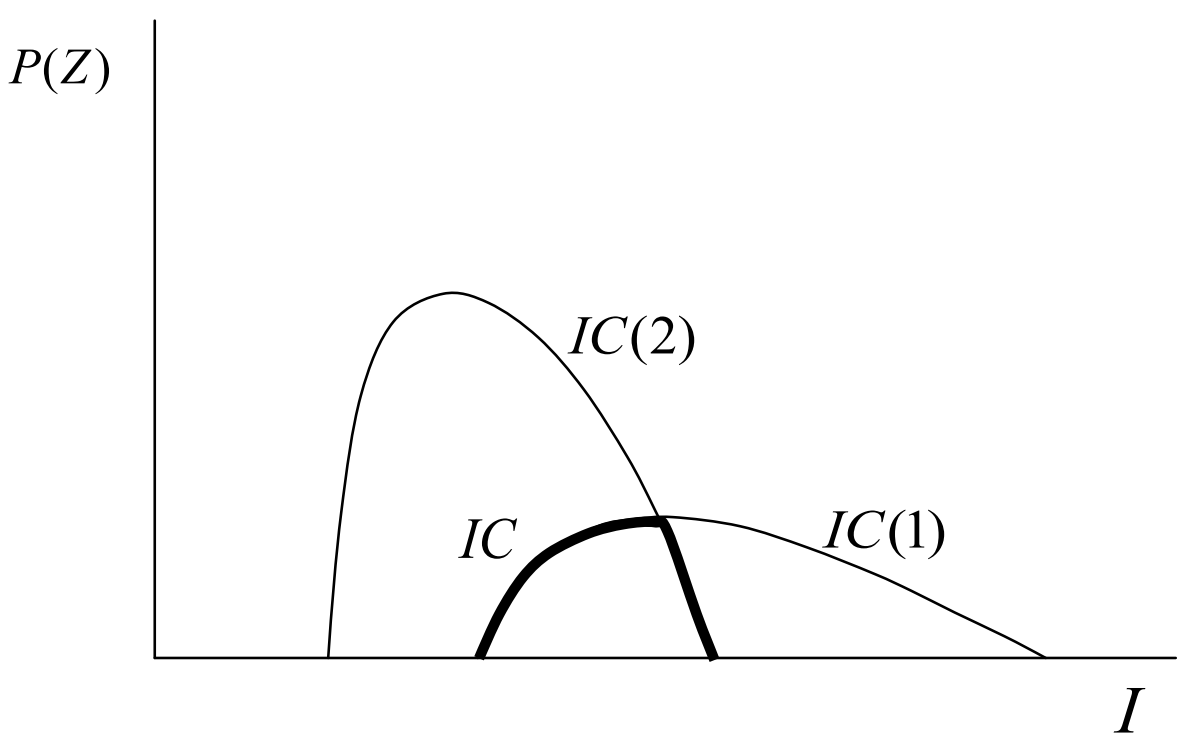

Notes: Figure I.2 shows the incentive constraint of the borrower (IC), given that it must make a net marginal return equal to the riskless interest rate, IC(2), and it must at least get an overall return from domestic investment that is as high as the return from using all the funds to buy riskless securities, IC(1). For any required repayment, $\mathrm{P}(\mathrm{Z})$, which exceeds the points on the incentive constraint, the borrower will have an incentive to use all of its funds to buy riskless securities, and default on the loan. 
Figure I.3. Incentive-Compatible Contracts

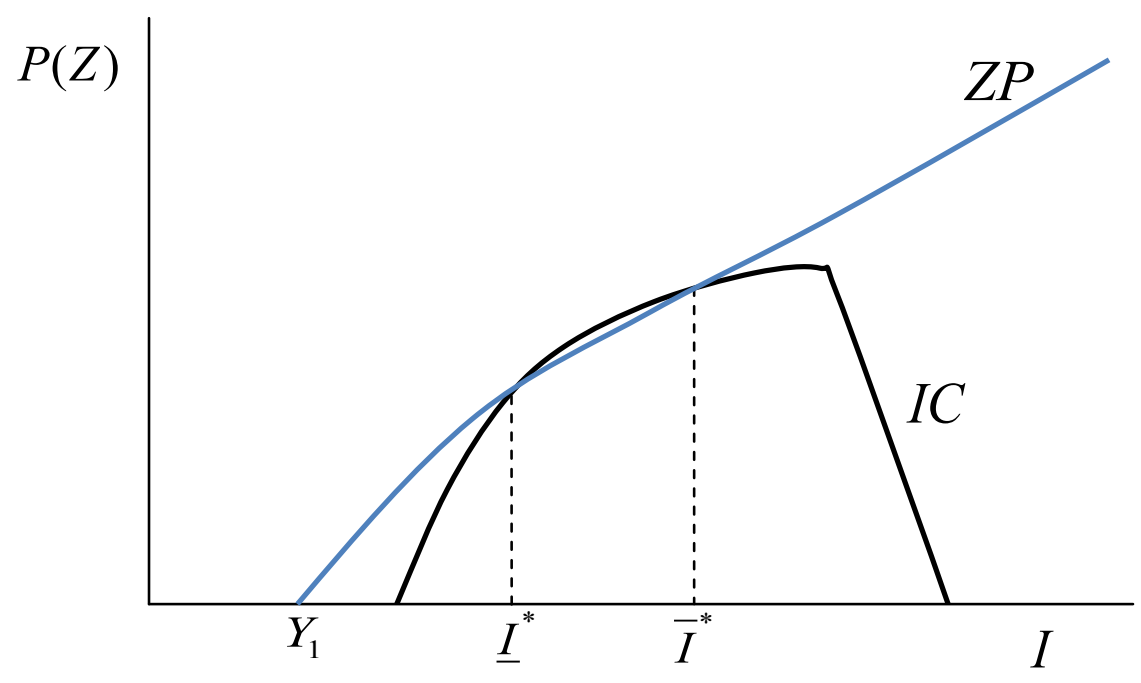

Notes: Figure I.3. displays the possible contracts given that the lenders make zero profit (ZP), and the borrower will get an expected net return of at least the world interest rate. In this example, the borrower and lenders can agree on a repayment, $\mathrm{P}(\mathrm{Z})$, for investment levels between $\underline{I}^{*}$ and $\bar{I}^{*}$. 
Figure I.4. Two-Country Equilibria

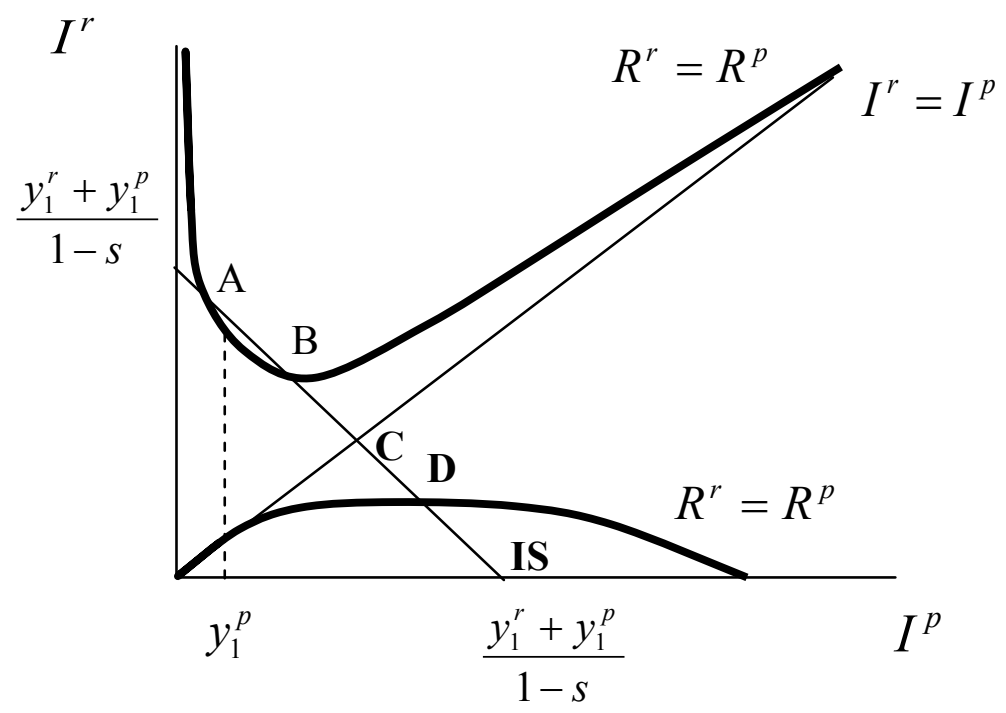

Notes: In Figure I.4., three possible equilibria are shown. Two curves represent where the interest rates are equalized across nations $\left(R^{r}=R^{p}\right)$, and the IS curve is where all savings is invested. Equilibrium will exist where all the funds are invested and the interest rates are equalized, such as at points $\mathrm{A}, \mathrm{B}$, and $\mathrm{D}$. Point $\mathrm{C}$ is the efficient point, but at the efficient point the rich country has a higher interest rate than the poor country because of the moral hazard problem. 
Figure I.5. Autarkic Interest Rates

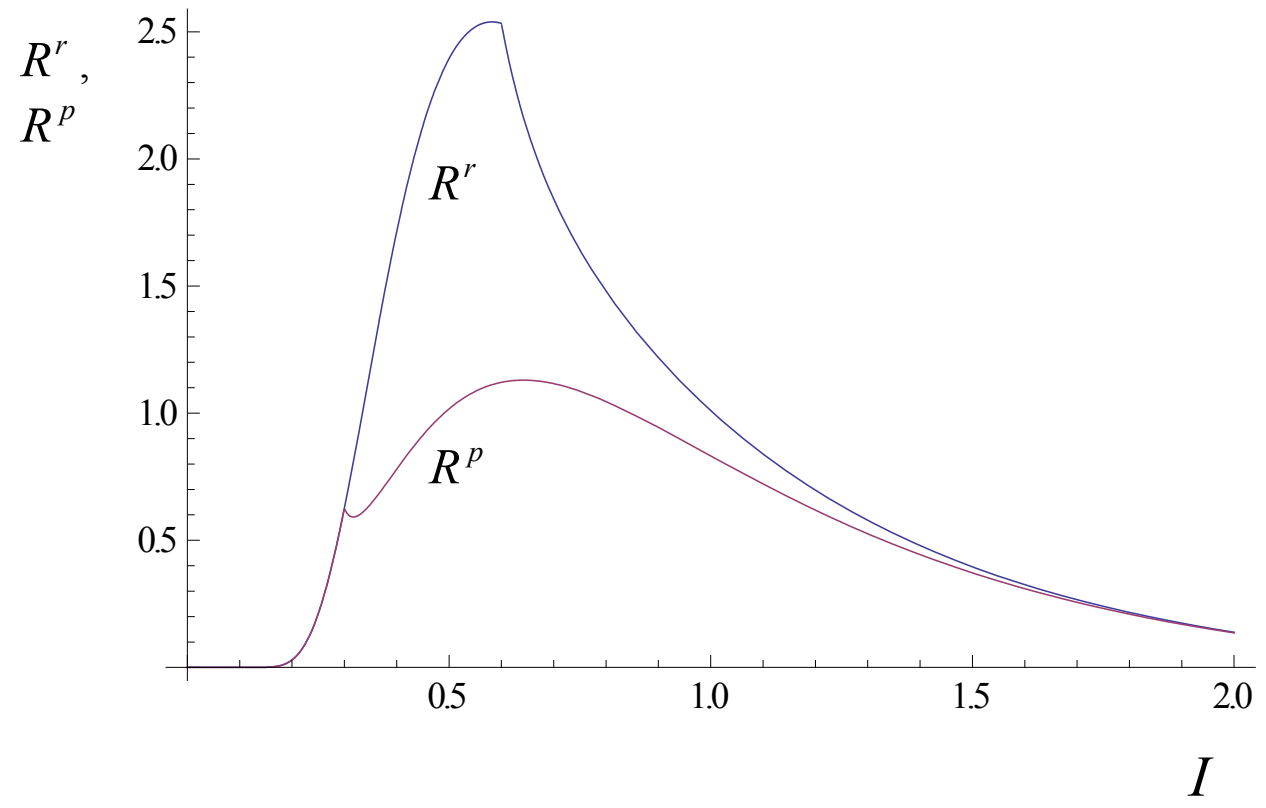

Notes: Figure I.5. shows the autarkic interest rates for the poor and the rich country at each given investment level. 
Table I.1. Possible Equilibria*

\begin{tabular}{|c|c|c|}
\hline \multicolumn{2}{|c|}{ Investment } & \multirow[b]{2}{*}{ World Interest Rate } \\
\hline Rich & Poor & \\
\hline 0.942 & 0.609 & 1.125 \\
\hline 1.164 & 0.389 & 0.746 \\
\hline 0.294 & 1.258 & 0.564 \\
\hline
\end{tabular}

Notes: Table I.1 shows three possible equilibria for a given income level of two countries. These are where all the funds are invested and the interest rates are equalized across countries. 


\section{INCREASING RETURNS, COLLATERAL, AND SOVEREIGN DEBT II.I. Introduction}

International capital flows have not flowed to capital-scarce countries as much as we would expect under diminishing returns to capital. In fact, capital has flowed mostly to the rich, capital-abundant countries. Explanations for this phenomenon, or the "Lucas Paradox" (1990), include fundamental differences, such as differences in institutions, education, or other missing factors of production. Explanations also include international capital market imperfections, such as asymmetric information and sovereign risk. In this paper, I will assume that there is a combination of sovereign risk, increasing returns to scale, and collateral differences across sectors that help explain why most capital has not flowed to the poor countries.

Another phenomenon that has received a lot of attention is the negative relationship between natural resource abundance and economic growth. Many empirical studies have shown that the more natural resource abundant, the lower the growth rate of per capita gross domestic product (for instance, see Sachs and Warner (1995) and Gylfason (2001)). Theoretically, the literature has given many reasons why natural resource abundance can be a curse (for a couple of the preliminary works, see Krugman (1987) and Matsuyama (1992)). In this paper, natural resources are not a curse, but instead the poor countries invest heavily in that sector because of the inability to access enough funds to invest in sectors that exhibit increasing returns to scale.

In a related phenomenon, studies have pointed out the existence of a bimodal or twin-peak world income distribution (for instance, see Quah (1996) and Jones (1997)). Since 1960, there seems to be a movement towards a cluster of countries at a low income and cluster of countries at a high income level. In this paper, I will show that poor 
countries can get stuck producing in less efficient sectors because of sovereign risk and collateral differences across sectors, while countries with sufficiently high income levels can take advantage of economies of scale.

My paper simultaneously explains the above three phenomena. I examine sovereign borrowing in a two-sector economy. The sovereign can invest in sectors such as natural resources (oil, minerals, timber, etc.), agriculture, and low-skilled manufacturing (textiles, toys, etc.), or the borrower can invest in sectors such as highskilled manufacturing (engineering, information technology, etc.) and other sectors that require investments in infrastructure (roads, bridges, utilities, etc.), education, and health. The first type of sectors require less initial investment and get higher returns at low levels of investment than the second type of sectors. The second type of sectors may yield higher returns than the first type of sectors, but only after a sufficient amount of capital is invested. The first type of sectors are characterized by diminishing returns to scale (DRS), while the second type of sectors are characterized by increasing returns to scale (IRS) at low levels of investment.

I find that countries below a threshold income level may only get enough loans to invest in the DRS sector, but countries above the threshold will invest mostly in the IRS sector. If the borrower could commit to repay the loans, then it could invest in the IRS sector and be better off, but it cannot commit to repay under high levels of debt because of the lack of punishment from default. It is also possible that even if the borrower had an incentive to repay the loan if the funds were invested as specified in a contract, the borrower may invest differently and default on the loan. Under collateral differences across sectors, the lender may only lend enough so that the sovereign will have an 
incentive to only invest in the less-productive sector. However, countries with sufficiently high income can receive enough loans to invest mostly in the IRS sector until they become indifferent between repaying and defaulting.

What can be done to help the poor countries? The results from this paper suggest familiar policy implications, which however are contingent on the income of the borrower. For example, if countries are stuck producing in sectors with low productivity, there can be several things that can be done to push them over the threshold to produce in the sectors with high productivity. One obvious remedy would be foreign aid. However, in this model, some foreign aid may have little effect on a poor country because the lenders may reduce the loan amount in fear of the sovereign investing in the IRS sector and defaulting. A sufficiently large amount of aid may give disproportionally more help to the poor country by inviting more loans to take advantage of increasing returns to scale. A country whose income level is sufficiently high will benefit from aid more than a very poor country because they can credibly commit to repay when investing in sectors that have increasing returns to scale. Another possible remedy, as pointed out in other sovereign debt models, is an increase in collateralization or punishment for default. However, in this model an increase in punishment can also substantially change the composition of investment in the sovereign nation. If a country has an incentive to only invest in the DRS sector, and the DRS sector becomes more collateralized, it may actually lead to an equilibrium with most investment in the IRS sector. In other models, monitoring investment may also benefit the borrower. However, in this model, the poorest borrowers will not benefit from monitoring. Countries with a sufficiently high income may benefit from monitoring, but the monitoring may only provide limited help. 
Though empirical evidence supports increasing returns to scale, theoretical literature incorporating such returns remains sparse. Investment in infrastructure and manufacturing has been shown to have increasing returns to scale. For instance, while testing for the existence of poverty traps, Rodriquez (2008) finds evidence of increasing returns to manufacturing across nations. Duggal, Saltzman, and Klein $(1999,2007)$ do an empirical study on infrastructure and IT in the U.S., and tests an s-shaped production function (similar to my assumption), and they find support for increasing returns at low levels of inputs. Fingleton and McCombie (1998) find evidence of increasing returns in EU manufacturing. Oliveira, Jayme, Jr., and Lemos (2006) find evidence of increasing returns in manufacturing in Brazil, and Park and Kwon (1995) find support for economies of scale in Korean manufacturing. Two exceptions that do discuss increasing returns and sovereign debt are Karayalcin, McCollister, and Mitra (2002) and Spiegel (1995). Karayalcin et al. (2002) show how including increasing returns in infrastructure can create a situation where a minimum amount of debt is necessary in order for repayment to be made. Spiegel shows that increasing returns could enhance long-term lending strategies.

In section II., I set up the model and solve the maximization problem of the borrower, given an income and debt level. The equilibrium debt level will be solved for in section III., including the case with collateral differences across sectors. In section IV., the relationship between income and debt will be examined, along with its implications regarding foreign aid and income distribution. Perfect monitoring of investment will be examined in section V., and the discussion will conclude in section VI. The functions and parameters used in the illustrations can be found in the appendix. 


\section{II.II. The Model}

I build a two-period, two-sector, small open-economy model of sovereign debt. The focus will be on the optimal actions of a social planner or government, and thereby I ignore any externality issues involved with increasing returns to scale (which could result in a bad equilibrium). In the first period, the borrowing country receives an endowment income, $Y_{1}$. Output in the second period, $Y_{2}$, depends on investment. A borrowing country can invest in two sectors of the economy, one with diminishing returns, and one with increasing returns to capital. The lenders can observe the output of the borrowing country, but they cannot control in which sector the borrowing country invests (this assumption will be relaxed later). The borrowing country is sovereign, so they can default on their loan. As in Obstfeld and Rogoff (1996), I assume that if a country defaults, the lenders can extract some portion of the borrower's output.

Although this model uses direct punishment in case of default, it may be difficult to validate it with many recent examples. Nonetheless, models based on reputation and fear of losing access to capital markets must also make assumptions that are difficult to justify. ${ }^{3}$ The reality is that there may be many reasons why a borrower does or does not default. A borrower may be in fear of sanctions or interference with trade, political repercussions, losing future access to credit markets, or the borrower may just be morally obliged to repay. While this paper uses direct punishments, the result is that the rich country can be punished more in absolute terms than a poor country in case of default.

\footnotetext{
${ }^{3}$ Models based on reputation must typically assume that the borrower must continuously need more funds in the future, and the borrowers are infinitely lived.
} 
This logic seems reasonable since a rich country typically has more collateral through more international entanglements than a poor country.

Depending on the type of investments, a country may be more or less susceptible to punishment in case of default. If a poor country invests the loan in natural resources and low-skilled manufacturing, sectors which poor countries tends to export, then defaulting on the loan can lead to costly sanctions or possibly a seizure of assets. If a poor country instead invests in a sector such as infrastructure or education, then defaulting on the loan may not result in much punishment. To compare and contrast with previous models, I will examine the problem under both identical and different punishments across sectors.

Although the borrower may have many considerations when deciding to repay a loan or default, including political or religious reasons, the focus in this paper will only be on financial incentives. Thus, the borrowing country chooses to repay only if default is too costly: Repayment $\left.\left.=\min \left[(1+r) D_{2}, n\left[F^{N}\left(K_{2}^{N}\right)+K_{2}^{N}\right)\right]+z\left[F^{M}\left(K_{2}^{M}\right)+K_{2}^{M}\right)\right]\right]$,

where $K_{2}^{N}$ is the capital devoted to the diminishing-returns sector, and $K_{2}^{M}$ is the capital devoted to the increasing-returns sector. Capital does not depreciate. $F^{N}\left(K_{2}^{N}\right)$ is the output from the diminishing-returns sector (DRS), and $F^{M}\left(K_{2}^{M}\right)$ is the output from the increasing-returns sector (IRS). $\quad D_{2}$ is the amount borrowed. The punishment for default is the fraction $n$ of the DRS good and $z$ of the IRS good.

Production in the IRS sector yields low returns for low levels of investment, but it exhibits increasing returns until the increasing returns are eventually exhausted and become diminishing returns after some investment level. Production in the DRS sector 
yields high returns for initial investment levels, but exhibits diminishing returns throughout. Graphically, the type of production functions which will be discussed are of the kind represented in Figure II.1. Although, in some instances, investment in IRS sectors may increase production in the DRS sectors, such as through infrastructure, I assume for convenience that it does not. Similarly, I assume that there is sufficient existing infrastructure (roads and bridges) to extract natural resources, and adding such infrastructure will mainly benefit other businesses.

In previous models of sovereign debt, borrowers may have an incentive to default by consuming more in the first period and investing less in the second period. For example, without uncertainty, a loan that exceeds a debt threshold could lead to a discontinuous crash in investment in order to reduce anticipated creditor sanctions (Obstfeld and Rogoff, 1996). That result would be the same in a two-sector model, making it even more difficult for a poor country to get enough loans to take advantage of increasing returns. In the two-sector set up, the borrower may not invest in the sectors as the lender may want, and this could also lead to default. To focus only on the investment composition decision and abstract from the effects of consumption smoothing or default stemming from first-period consumption, I assume that the representative agent of the small country gets utility only from second-period consumption:

$U\left(C^{N}, C^{M}\right)=C_{2}^{N}+C_{2}^{M}$.

For ease of exposition, set prices equal to one for both goods, and those prices are taken and do not change. Since prices are taken by the sovereign, the borrower only cares about maximizing its output, which would then maximize its consumption and utility. Investment in each sector is 
$I_{1}^{M}=Y_{1}+D_{2}-I_{1}^{N}=K_{2}^{M}$

and

$I_{1}^{N}=Y_{1}+D_{2}-I_{1}^{M}=K_{2}^{N}$.

Consumption in the second period is

$C_{2}=F^{N}\left(K_{2}^{N}\right)+F^{M}\left(K_{2}^{M}\right)+K_{2}^{N}+K_{2}^{M}-\Re$,

where $\mathfrak{R}$ is the repayment. Since the borrowing country cannot commit to repay, its repayment must never exceed the cost of sanctions. The lenders must make $(1+r) D_{2}$ in order to be willing to lend. Therefore, the sanctions under default must be at least as large as the risk-free return on the debt,

$n\left[F^{N}\left(K_{2}^{N}\right)+K_{2}^{N}\right]+z\left[F^{M}\left(K_{2}^{M}\right)+K_{2}^{M}\right] \geq(1+r) D_{2}$.

The borrowing country is therefore trying to solve:

$\max _{K_{2}^{N}, K_{2}^{M}} F^{N}\left(K_{2}^{N}\right)+K_{2}^{N}+F^{M}\left(K_{2}^{M}\right)+K_{2}^{M}-$
$\min \left[(1+r) D_{2}, n\left[F^{N}\left(K_{2}^{N}\right)+K_{2}^{N}\right]+z\left[F^{M}\left(K_{2}^{M}\right)+K_{2}^{M}\right]\right]$,

given $D_{2}=K_{2}^{N}+K_{2}^{N}-Y_{1}$. Under default, the maximization problem is

$$
\begin{aligned}
& \max _{K_{2}^{N}, K_{2}^{M}} F^{N}\left(K_{2}^{N}\right)+K_{2}^{N}+F^{M}\left(K_{2}^{M}\right)+K_{2}^{M}- \\
& n\left[F^{N}\left(K_{2}^{N}\right)+K_{2}^{N}\right]-z\left[F^{M}\left(K_{2}^{M}\right)+K_{2}^{M}\right] .
\end{aligned}
$$

Solving, if an interior maximum exists, the maximum is where the net marginal rates of return are equalized:

$\left(f^{\prime N}+1\right)(1-n)=\left(f^{M}+1\right)(1-z)$.

Under repayment, the maximization problem is 


$$
\begin{aligned}
& \max _{K_{2}^{M}, K_{2}^{N}} F^{M}\left(K_{2}^{M}\right)+F^{N}\left(K_{2}^{N}\right)+K_{2}^{N}+K_{2}^{M}-(1+r) D_{2} \\
& =\max _{K_{2}^{M}, K_{2}^{N}} F^{M}\left(K_{2}^{M}\right)+F^{N}\left(K_{2}^{N}\right)+K_{2}^{N}+K_{2}^{M}-(1+r)\left(K_{2}^{N}+K_{2}^{M}-Y_{1}\right) .
\end{aligned}
$$

Solving, if an interior maximum exists, then the maximum is achieved where the marginal rates of return are equalized, $f^{\prime N}=f^{\prime M}$. Given an income and debt level, there can be at least two points that set the marginal rates equal (one may be a minimum). As will be discussed, if the initial income of the borrower is too low, the maximum utility will be achieved when all the funds are invested in the decreasing-returns sector. A key assumption that is made here is that the sovereign borrower does not have enough funds to invest efficiently in both sectors, where $f^{{ }^{N}}=f^{M}=r$, nor will the sovereign nation be able to borrow enough to make the efficient investments because of the incentive to default.

In order to get explicit solutions, I would have to specify explicit production functions and parameters, which is done in the background to help illustrate the results (see appendix), but they are not specified here since the parameters and numbers are arbitrary. However, I can implicitly describe the possible equilibrium under reasonable assumptions. We know that the lenders will not lend any amount which will lead to default, but they will lend as much as possible up to that amount if the lenders are competitive. The amount of the loan depends on how much the lenders expect the borrower to invest in each sector. To compare these results to previous models, let us first assume $n=z$, and then we can look at the implications of different punishments for different sectors. Under equal punishments across sectors, if there is an interior equilibrium, investments will be made until marginal returns are equalized between the 
two sectors, $f^{\prime N}\left(K_{2}^{N}\right)=f^{\prime M}\left(K_{2}^{M}\right) \geq r$. In this case, regardless of whether the borrower has an incentive to default or repay, if an interior maximum exists, it is achieved when the marginal products are equalized. If the borrower is defaulting, then capital will flow to the sector with the highest net marginal return, $\left(f^{\prime N}+1\right)(1-n)$ or $\left(f^{\prime M}+1\right)(1-z)$, but if $n=z$, this reduces to $f^{\prime^{N}}\left(K_{2}^{N}\right)$ or $f^{\prime M}\left(K_{2}^{M}\right)$, which is also the optimal allocation under repayment. Thus, if the borrower is being punished by the same fraction of output, whether output came from the DRS or IRS sector, if there is an interior maximum, it is achieved when the marginal products are equalized across sectors. Therefore, given an income and debt level, the optimal investment-composition decision of the borrower does not depend on whether it is repaying or defaulting if the collateral is the same across sectors.

Figure II.2. illustrates the investment-composition decision of the borrower given its income and loan amount, while under equal punishment fractions across sectors. Given the utility function, the borrower will invest everything, so the only question is how much will be invested in each sector, and whether the borrower will repay or default. Figure II.2. shows the possible equilibria if the borrower is given a credit constraint, $Y_{1}+D_{2}=\bar{I}$. Given an income and loan, the line $\bar{I}$, with a slope of negative one, represents all the different combinations of investment that the borrower can make in the two sectors. For instance, if all the income and loans were invested in the diminishingreturns sector (increasing-returns sector), the borrower would be at the vertical (horizontal) intercept on the $\bar{I}$ line in Figure II.2. 
Points $\mathbf{B}$ and $\mathbf{G}$ in Figure II.2. represent the two possible interior equilibrium investment levels given an income and debt level. These points are the possible interior equilibria because all funds are invested and the marginal returns in each sector are equalized (although point $\mathbf{B}$ could be a minimum). The curved line represents where the marginal returns are equalized, $f^{\prime N}\left(K_{2}^{N}\right)=f^{\prime M}\left(K_{2}^{M}\right)$, and it is U-shaped because of the shape of the production functions. For instance, a large investment in the diminishingreturns sector will yield a similar marginal product as a small investment in the increasing-returns sector, such as the case at point $\mathbf{B}$. As investment in the IRS sector increases, the marginal return increases in the IRS sector, and an equivalent marginal return in the DRS sector would be achieved with less investment. Once investment in the IRS sector is large enough such that the increasing returns are exhausted, then more investment in the IRS sector will achieve lower marginal returns, such as the marginal returns achieved with more investment in the DRS sector, and this explains the U-shaped curve.

The dotted line in Figure II.2. represents the minimum amount of income and debt needed to make investment in the IRS sector possible. If $\bar{I}$ was inside the dotted line, then all the investment would be in the DRS sector since the marginal return of the IRS sector never reaches the marginal return from the DRS sector. For sufficiently low income levels, and consequently fewer loans, even if everything was invested in the IRS sector, the marginal return in the IRS sector may still be lower than what the marginal return would be if everything was invested in the DRS sector. Therefore, the borrower would never have an incentive to invest anything in the IRS sector if the credit constraint was inside the dotted line in Figure II.2. 
However, even if the credit constraint was to the right of the dotted line, the borrower may still not have an incentive to invest any in the DRS sector. Even if a higher marginal return can be achieved by investing all the funds the IRS sector as opposed to investing all in the DRS sector, the borrower may still get more output by investing only in the DRS sector. To get high marginal returns in the IRS sector, the borrower has to accept low marginal returns at low levels of investment, which may not be worth it unless the investment is large enough. Therefore, all capital will flow into the DRS sector if the income is too low and the loan is insufficient for the borrower to invest in both sectors. The amount of income necessary for investment in the DRS sector will be illustrated in the next section when the equilibrium debt level is solved for.

When punishment for default is the same fraction of output no matter which sector the output comes from, then the lender knows that the borrower will invest in a way that maximizes gross output. The question for the lenders is how large can the loan be until the borrowers have an incentive to default. If the borrower was punished differently according to the sector from which the output comes from, $n \neq z$, then Figure II.2. would also have to include a curve which represents where the net marginal returns are equalized, $\left(f^{\prime N}+1\right)(1-n)$ or $\left(f^{\prime M}+1\right)(1-z)$. The borrower would then have to compare the value of its optimal decision under default, with an interior maximum achieved where the net marginal returns are equalized, with its optimal decision under repayment, where an interior maximum is achieved where the marginal returns are equalized. The lenders would have to solve the borrower's problem in order to know how much they can lend. This analysis is done in the next section. 


\section{II.III. The Equilibrium Debt Contract}

The previous section solves the investment composition decision of the borrower given an income and debt level, but the decision of the borrower may affect the amount of the loan that the lenders would be willing to give in the first place. The difficulty is solving for the amount of the loan that the lenders would lend, given that the borrower can use the loan to invest in whatever sector it wants and may default depending on the composition of the investment. However, if we assume that the punishment for default is the same across sectors, $n=z$, then the lenders do not need to worry about the borrower's composition of investment, they only need to worry about loaning too much. This means that if the lenders give a loan that the borrower would repay if it invested according to the contract, the borrower would not have an incentive to invest differently and default. If we assume that punishment differs across sectors, $n \neq z$, then the lenders may have to decrease the loan because the borrower may not invest in a way that would create an incentive for repayment, even if the borrower would have an incentive to repay if it invested according to the contract. In either case, in order for the lenders to know how much they can loan to the borrower and still get repaid, they must know the highest amount of debt that would make the borrower indifferent between repaying and defaulting.

First, we know that if the borrower has a sufficiently low income, then at low levels of debt, the borrower will not have an incentive to invest anything in the IRS sector if we assume the IRS sector yields low marginal returns at low levels of investment and the DRS sector yields high marginal returns at low levels of investment. However, with enough income and debt, the borrower may be able to invest enough to take advantage of 
the increasing returns, with the optimal amount of investment being where the net marginal products of capital are equalized across sectors. Therefore, the value of defaulting can be written as

$$
\begin{aligned}
V^{d}= & \max \left[(1-n)\left[F^{N}\left(Y_{1}+D_{2}\right)+Y_{1}+D_{2}\right],(1-n)\left[F^{N}\left(\alpha\left(Y_{1}+D_{2}\right)\right)+\alpha\left(Y_{1}+D_{2}\right)\right]\right. \\
& \left.+(1-z)\left[F^{M}\left((1-\alpha)\left(Y_{1}+D_{2}\right)\right)+(1-\alpha)\left(Y_{1}+D_{2}\right)\right]\right],
\end{aligned}
$$

where, $\quad D_{2}=K_{2}^{N}+K_{2}^{M}-Y_{1}, \quad \alpha=\frac{\hat{K}_{2}^{N}}{\hat{K}_{2}^{M}+\hat{K}_{2}^{N}}, \quad$ and $\quad \hat{K}_{2}^{N}, \hat{K}_{2}^{M}$ solves the first-order condition $(1-n)\left(f^{\prime N}+1\right)=(1-z)\left(f^{\prime M}+1\right)$ that corresponds to an interior maximum (not a minimum). The equation states that under default the borrower may get the most value from investing everything in the DRS sector and keeping the fraction $1-n$ of their output and investment; or the borrower may get the most value from keeping a fraction of their output and investment from both sectors, while investing in each sector so that the net marginal returns are equalized. As discussed above, at low levels of income and debt the borrower will get the most value from investing everything in the DRS sector, while at high levels of income and debt the borrower will get the most value by investing mostly in the IRS sector.

Analogously, the value of repayment can be written as

$$
\begin{aligned}
V^{R}= & \max \left[F^{N}\left(Y_{1}+D_{2}\right)+Y_{1}+D_{2}-(1+r) D_{2},\right. \\
& \left.F^{N}\left(\gamma\left(Y_{1}+D_{2}\right)\right)+F^{M}\left((1-\gamma)\left(Y_{1}+D_{2}\right)\right)+\left(Y_{1}+D_{2}\right)-(1+r) D_{2}\right],
\end{aligned}
$$

where $\gamma=\frac{\widetilde{K}_{2}^{N}}{\widetilde{K}_{2}^{M}+\widetilde{K}_{2}^{N}}$, and $\widetilde{K}_{2}^{N}, \widetilde{K}_{2}^{M}$ solves the first-order condition $f^{\prime N}=f^{\prime M}$ that corresponds to an interior maximum. Under repayment, the borrower may get the most net output from investing everything in the diminishing-returns sector; or the borrower 
may get the most net output from investing in both sectors in such a way that sets the marginal returns equal across sectors. The equilibrium debt is the amount that sets the utility from defaulting equal to the utility from repayment, $V^{R}=V^{d}$. Any debt that exceeds that amount will result in default, while the lenders have no reason to restrict debt below such an amount.

First, we can illustrate the outcomes under the assumption of equal default punishment fractions across sectors, $n=z$. A sufficiently low income will lead to a loan that will not be large enough in order for the borrowers to have an incentive to invest in the increasing-returns sector. This case is illustrated in Figures II.3a. and II.3b. In Figure II.3a., the value of repayment and the value of default are shown at each debt level, given an initial income level $Y_{1}$. Each of the curves has a kink, which represents the debt level at which investment goes from only the diminishing-returns sector to a combination of the DRS and IRS sector. As explained before, at low investment levels, where investment equals $Y_{1}+D_{2}$, the borrower has an incentive to only invest in the DRS sector. At some higher investment level, the borrower will have an incentive to invest in both sectors at the point where the marginal returns are equalized. After the kink, the value of default and the value of repayment increases at a higher rate than before because of increasing returns. In this example, however, the borrower is too poor to receive enough loans to have an incentive to invest in the IRS sector. The value of default and the value of repayment are equalized at the debt level, $D_{2}^{*}$, which is not enough for the borrower to invest in the IRS sector. 
As debt increases, both the value of repayment and the value of default increase; and under plausible parameters, the value of default will increase more than the value of repayment. To show this, I need to show that $\partial V^{d} / \partial D_{2}>\partial V^{R} / \partial D_{2}$. For example, if all investment is in the DRS sector, the inequality is true if $1+r>n\left(1+f^{\prime N}\left(K_{2}^{N}\right)\right)$, where $f^{\prime N}\left(K_{2}^{N}\right)$ is the marginal return in the DRS sector. This condition is true with any reasonable parameter. In the case where investment is in both sectors, the assumption that default becomes more attractive as debt increases is also true under plausible parameters, although the necessary inequality does not simplify as neatly. Note that this implies that there is not a range of default, where higher debt makes repayment more attractive. Throughout this paper, it will be assumed that the value of default increases more than the value of repayment as debt increases, which will be the same as assuming that we will not have a combination of both extremely severe punishment for default and extremely high marginal returns.

Figure II.3b. illustrates the relationship between debt and the composition of investment. For low levels investment, all the funds, $Y_{1}+D_{2}$, will go to the diminishingreturns sector, since the increasing-returns sector only yields sufficient returns at high levels of investment. In this example, the equilibrium debt level is not enough to entice the borrower to invest any funds in the IRS sector. As we can see in Figure II.3b., there is a debt level, which is higher than the equilibrium debt level, where the amount of funds invested in the diminishing-returns sector falls, while the borrower invests most funds in the increasing-returns sector. Since all funds are invested, the difference between total 
investment, $Y_{1}+D_{2}$, and investment in the DRS sector, $K_{2}^{N}$, is the investment in the IRS sector, $K_{2}^{M}$.

Once income is sufficiently large, the borrowers can get enough loans to make investment in the IRS sector worthwhile. When the punishment fractions for default are the same across sectors, there is a threshold income level that allows just enough debt so that the borrower is indifferent between investing only in the DRS sector and investing in both sectors such that the marginal products are equalized. As illustrated in Figures II.4a. and II.4b., at such an income level, the lenders would be willing to give just enough loans such that the borrower is not only indifferent between repaying and defaulting when investing in the DRS sector, but the borrower is also indifferent between repaying and defaulting while investing optimally in both sectors. A lower income level will lead to less debt and will give the borrower an incentive to only invest in the DRS sector. A higher income level will lead to more debt and will give the borrower an incentive to mostly invest in the IRS sector.

It may not be obvious that there exists an income level that will allow the borrower just enough debt to make it indifferent between repaying and defaulting at two sets of investment levels, as illustrated in Figure II.4b. For a given income level, the borrower will be given loans until it becomes indifferent between repaying and defaulting; and depending on the income level, the highest debt that sets $V^{d}=V^{R}$ may be where the borrower invests only in the DRS sector, or it may be large enough for the borrower to invest in the IRS sector. For the income level that yields enough debt to make the borrower indifferent between repayment and default under DRS investment, if 
it gives the same utility for investing in both sectors and repaying, then it must also give the same utility from investing in both sectors and defaulting. If the value of repayment under only DRS investment is equal to the value of repayment when investment is made in both sectors, it must mean that the output is the same at each set of investments. If the value of default is equal to the value of repayment at one of those points, then it must be the case that the value of default is equal the value of repayment at both points. If the output is the same, and the punishment for default is the same fraction no matter which investments took place, then the net output will be the same at both points. Therefore, we have the situation in Figure II.4b., where the value of default and the value of repayment are equal at two points at the threshold income level. We will see later that if we assume different punishments across sectors, then we will have a different threshold since the optimal investment composition depends on whether the borrower will default or repay (in such a case, it is not obvious that $\partial V^{R} / \partial Y_{1}>\partial V^{d} / \partial Y_{1}$ ).

At a lower income level than illustrated in Figures II.4a. and II.4b., the situation is that of Figures II.3a. and II.3b., where the borrower is only given enough debt to set the value of default equal to the value of repayment when investment is only in the DRS sector. At a higher income level than in Figures II.4a. and II.4b., the highest debt that achieves $V^{d}=V^{R}$ will be where the borrower invests mostly in the IRS sector. Such an equilibrium debt and the composition of investment are illustrated in Figures II.5a. and II.5b.

In Figure II.5a., the borrower's income is high enough so that it can get enough debt to have an incentive to invest in the IRS sector. The value of default and the value of repayment intersect after the kinks in the curves, which is where the borrower has 
enough funds to take advantage of the increasing returns. In Figure II.5b., we see that for the given income and debt level, the borrower will choose to invest most funds in the IRS sector (the difference between the two lines), where the marginal products are equalized across sectors. When we assume the same punishment fraction across sectors, the curves will never cross where the value of default and the value of repayment are on different sides of the kink in the curves in Figure II.5a., where the borrower would be indifferent between investing only in DRS sector and repaying and investing in both sectors and defaulting. However, as we will see later, if we assume different punishments then we can have such a case.

\section{Equilibrium under different default punishments for each sector, $n>z$}

As described earlier, the diminishing-returns sector may be more collateralized than the increasing-returns sector. If a poor country invests in natural resources and lowskilled manufacturing, sectors from which poor countries tends to export, then defaulting on a loan may lead to costly sanctions or possibly a seize of assets. If a poor country instead invests in sectors such as infrastructure or education, then defaulting on an international loan may not result in much punishment. For instance, oil revenues may be easier to extract than a bridge or a school. Therefore, we should set $n>z$, and examine the effect that has on equilibrium debt and investment composition.

If a borrower is very poor, then the equilibrium under different sector punishments will look similar to Figures II.3a. and II.3b. The borrower will not have enough income and debt to have an incentive to invest in the IRS sector. The lender will give a loan that will make the borrower indifferent between repaying and defaulting, and at a sufficiently low income level, the borrower will be indifferent between repaying and 
defaulting after investing only in the DRS sector. At a higher but still sufficiently low income level, we get a result that differs from Figures II.3a. and II.3b. and from Figures II.4a. and II.4b. The borrower may still not have enough income to get a large enough loan to invest in the IRS sector, but the lenders may give a loan that makes the borrower indifferent between investing in the DRS sector and repaying and investing mostly in the IRS sector and defaulting.

As illustrated in Figure II.6a., the debt that makes the borrower indifferent between repaying and defaulting is after the kink in the $V^{d}$ curve, but it is before the kink in the $V^{R}$ curve. This means that at the equilibrium debt level, the highest value from defaulting comes from investing mostly in the IRS sector, but the highest value from repaying comes from investing everything in the DRS sector. When repaying, utility is maximized by either investing where the marginal returns are equalized, $f^{\prime N}\left(K_{2}^{N}\right)=f^{\prime M}\left(K_{2}^{M}\right)$, or where everything is invested in the DRS sector, whichever yields the most gross output. When defaulting, utility is maximized by either investing where the net marginal returns are equalized $(1-n)\left(f^{\prime N}+1\right)=(1-z)\left(f^{\prime M}+1\right)$, or where everything is invested in the DRS sector, whichever yields the most net output. If $n>z$, then an interior maximum under default is achieved when the gross marginal return in the DRS sector is higher than the gross marginal return in the IRS sector. Therefore, net output under default may be higher when investment is mostly in the IRS sector, even if gross output is greater when everything is invested in the DRS sector. At an income that is almost high enough, but still insufficient to yield enough debt to invest in the IRS sector, the borrower will be given enough loans such that they are indifferent between 
investing and repaying in the DRS sector and investing mostly in the IRS sector and defaulting. In this example, the lenders do not want the borrower to invest in the IRS sector because of the lack of punishment if the borrowers default after investment in that sector.

In Figure II.6b., we see that the utility from repaying is maximized when all funds are invested in the DRS sector, but utility from defaulting is maximized when most funds are invested in the IRS sector and $K_{2}^{N D}$ is invested in the DRS sector, which is where the net marginal returns are equalized. For very low income and debt levels, the utility from repaying and the utility from defaulting are both maximized when investment is only in the DRS sector, such as in Figures II.3a. and II.3b. At high levels of income, both the utility from repaying and the utility from defaulting is maximized when most investment is made in the IRS sector. Therefore, there exists some threshold income level that yields just enough debt such that the borrower is indifferent between investing only in the DRS sector and repaying, investing mostly in the IRS sector and repaying, and investing some greater proportion in the IRS sector and defaulting. Such an income level is illustrated in Figures II.7a. and II.7b.

As illustrated in Figure II.7a., the initial income is just large enough such that the equilibrium debt level is at the kink in the $V^{R}$ curve, which means the borrower is indifferent between investing everything in the DRS sector and repaying and investing mostly in the IRS sector and repaying, and investing mostly in the IRS sector and defaulting. There is no kink in the default curve in this example, which means the borrower has enough initial income that it would always want to invest in the IRS sector if it was to default. When output from the DRS sector is more collateralized than output 
from the IRS sector, then at the threshold income level the value from defaulting will be maximized when most of the funds are invested in the IRS sector. This occurs because at a given output level the borrower will get more net output from investing mostly in the IRS sector under default since the IRS sector has less collateral. Therefore, while the value of repayment from investing only in the DRS sector equals the value of repayment from investing mostly in the DRS sector, the value of default from investing only in the DRS sector is less than the value of default from investing mostly in the IRS sector.

Figure II.7b. shows the investment composition at a threshold income level under different punishments across sectors. As we can see from the vertical dotted line, three sets of investment levels achieve the same utility. The borrower can invest everything in the DRS sector (set $Y_{1}+D_{2}=K_{2}^{N}$ and $K_{2}^{M}=0$ ) and repay, or the borrower can invest mostly in the IRS sector where the marginal products are equalized and repay, or the borrower can invest a greater proportion in the IRS sector where the net marginal products are equalized (where $\left.(1-n)\left(f^{\prime N}+1\right)=(1-z)\left(f^{\prime M}+1\right)\right)$ and default. At that given income level, any more debt and the borrower will have an incentive to invest mostly in the IRS sector and default (under plausible parameters, $\partial V^{d} / \partial D_{2}>\partial V^{R} / \partial D_{2}$ ).

If income was higher than the level illustrated in Figures II.7a. and II.7b., then the borrower would be allowed enough debt to invest mostly in the IRS sector. In general, however, when the IRS sector is less collateralized than the DRS sector, more income doesn't mean more debt, as will be illustrated later. However, once the borrower's income crosses the threshold level shown in Figures II.7a. and II.7b., more income will allow for more debt and investment in the IRS sector, assuming plausible parameters. At 
a higher income level than portrayed in Figure II.7a., the $V^{R}$ curve will increase more than the $V^{d}$ curve, which will allow for more debt. It can be shown that $\partial V^{R} / \partial Y_{1}>\partial V^{d} / \partial Y_{1}$ for any given reasonable parameters when comparing the interior maximums or when comparing the case where everything is invested in the DRS sector. However, when looking at the case where the borrower is getting just enough income to have an incentive to invest in the IRS sector under default, then an income may not allow for more debt, as will be shown later.

\section{A Change in Collateral}

With equal punishment fractions across sectors, $n=z$, it may be obvious that an increase in punishment may allow a borrower to take advantage of increasing returns and invest mostly in the IRS sector. For example, under equal punishments across sectors, if the lenders could increase the punishment for default, the borrowers will be willing to repay a larger amount of debt, which will allow for more loans and may give the borrower an incentive to invest mostly in the IRS sector. If the borrower was near the threshold as in Figure II.4a., then increasing the punishment will shift the $V^{d}$ curve down and to the right in Figure II.4a., which will increase the equilibrium debt. The result would then look like Figures II.5a. and II.5b., where the borrower has an incentive to invest mostly in the IRS sector.

What may not be obvious, however, is that if the punishment is greater in the DRS sector, $n>z$, then increasing punishment in the DRS sector may also allow the borrower to contract for enough funds to invest mostly in the IRS sector, even if it means that the borrower is investing less in the DRS sector than with the lower punishment. Also, increasing $n$ may actually decrease the total amount of collateral since the 
borrowers may invest mostly in the IRS sector, of which a smaller fraction is collateral. For instance, suppose that the income and punishment fractions gave the borrower an incentive to invest only in the DRS sector, where the punishment for defaulting is $n\left(F^{N}\left(Y_{1}+D_{2}\right)+Y_{1}+D_{2}\right)$. Suppose at the equilibrium, as in Figures II.6a. and II.6b., the borrower is given just enough debt to be indifferent between investing only in the DRS sector and repaying and investing in both sectors and defaulting, which can be expressed as

$$
\begin{aligned}
& \max V^{R}=F^{N}\left(Y_{1}+D_{2}\right)+Y_{1}+D_{2}-(1+r) D_{2}= \\
& \max V^{d}=(1-n)\left[F^{N}\left(\alpha\left(Y_{1}+D_{2}\right)\right)+\alpha\left(Y_{1}+D_{2}\right)\right]+(1-z)\left[F^{M}\left((1-\alpha)\left(Y_{1}+D_{2}\right)\right)+(1-\alpha)\left(Y_{1}+D_{2}\right)\right],
\end{aligned}
$$

where $\alpha$ is the fraction of the funds that are invested in the DRS sector when the net marginal returns are equalized across sectors. When $n$ is increased, the maximum utility from defaulting decreases since the borrower is receiving a smaller fraction from the DRS sector output under default, and at the original debt level the maximum that can be achieved from repaying exceeds the maximum that can be achieved from defaulting, $\max V^{R}>\max V^{d}$. If the utility from repayment is higher than the utility from defaulting, the lenders can give more loans until the borrower becomes indifferent between repaying and defaulting. As the amount of loans increase, both the value of default and the value of repayment increases, with the value of defaulting increasing at a higher rate than the value of repaying (again assuming $\partial \max V^{R} / \partial Y_{1}>\partial \max V^{d} / \partial Y_{1}$, which is true under any plausible parameters). A new equilibrium debt level may be achieved where the borrower may have an incentive to invest in the IRS sector and repay. 
An increase in $n$ is illustrated in Figure II.8. The dotted line represents the value of default after an increase in punishment on output from the decreasing-returns sector. At the old equilibrium debt level, $D_{2}^{*}$, the maximum value from repaying exceeds the maximum value from defaulting after the increase in punishment for the decreasingreturns sector output under default. At the new equilibrium debt level, $D_{2}^{* \prime}$ in Figure II.8, the borrower invests in both sectors such that the marginal returns are equalized, $f^{\prime N}\left(K_{2}^{N}\right)=f^{\prime M}\left(K_{2}^{M}\right)$, and repays the debt. The borrower would also get the same utility from investing in both sectors such that the net marginal returns are equalized, $(1-n)\left(f^{\prime N}+1\right)=(1-z)\left(f^{\prime M}+1\right)$, and defaulting. At the new equilibrium debt level, the borrower would have defaulted at the old punishment fraction of the DRS sector output. However, when $n$ increases, the collateral for investment in both sectors is now high enough to entice the borrower's to repay, with the total punishment under default equaling

$n\left[F^{N}\left(\alpha\left(Y_{1}+D_{2}\right)\right)+\alpha\left(Y_{1}+D_{2}\right)\right]+z\left[F^{M}\left((1-\alpha)\left(Y_{1}+D_{2}\right)\right)+(1-\alpha)\left(Y_{1}+D_{2}\right)\right]$

Before the increase in $n$, if the borrower invested everything in the DRS sector and did not repay, then the actual collateral taken by the lenders may be more than what they could have taken if the borrower defaulted after the increase in $n$. The output from the borrower will be more, but the fraction of output extracted by the lender under default may be less than before since the IRS sector is not highly collateralized. Thus, an increase in collateral in the DRS sector may actually decrease overall collateral, yet it still may make it possible to sustain a contract for more funds, and possibly enough to take advantage of increasing returns to scale. Of course, having less collateral after an 
increase $n$ is a little misleading. If the borrower defaults, the investment would be different than if it repaid, and the punishment would be higher after the increase in $n$.

For example, suppose a contract added a clause that allowed the lending country to seize oil export revenues in case of default on the loan. Adding this collateral would increase the amount of the loan for any given contract in which the borrower would produce (and export) oil. Further, suppose the borrower has been too poor to invest in industries with increasing returns to scale, such as the case illustrated in Figures II.6a. and II.6b. Before the added clause, lenders would not loan enough money for borrower to invest in both sectors where the marginal products are equalized, since the borrower has less collateral in the IRS sector and would have an incentive to default. However, with the added punishment for default with oil output, the borrower may now have an incentive to repay a loan that allows the borrower to invest in both the IRS and DRS (oil) sector. This is possible since the portion that is invested in oil production, when marginal products are equalized, is punished at a higher fraction than before the clause. Before the clause, if the borrower invested in both sectors, it would default, but adding more punishment in the DRS sector could bring down the utility from default just enough to make repayment optimal. The result from including the possibility of expropriating oil exports may be less oil produced, since a lot of funds are now invested in other sectors, but the borrower will still get a larger loan and achieve higher overall output. The total collateral that can be seized by the lenders under default may actually decrease because the output from the IRS sectors may have less collateral than the DRS sector. However, if the borrower would have defaulted before the clause, it would have invested in both sectors, but after the clause the punishment for such an investment increases. In previous 
models, increasing the punishment for default benefits the borrower, but in this model it can also shift investment to more productive sectors, and the increase in punishment can have a more substantial impact because of increasing returns to scale.

\section{II.IV. Income and Debt}

After analyzing the possible contracts under different initial income levels, we can now describe a general relationship between initial income and debt. In Figure II.9., the relationship between initial income and debt is drawn, given that the DRS sector is more collateralized than the IRS sector, $n>z$. A borrower with an initial income of zero can still contract for some funds, given that the initial returns are very high in the DRS sector, and subsequently the punishment for default is high since the lender will take a fraction

of the output. For higher levels of initial income, up to $Y_{1}^{1}$, the amount of collateral increases, and the returns are high, so the amount of loans increase. In this range, the borrowers are investing only in the DRS sector since they do not have enough funds to take advantage of increasing returns. Because of diminishing marginal returns, the curve is concave, since the punishment will increase with more income and investment, but at a diminishing rate.

Once initial income surpasses the level $Y_{1}^{1}$, the amount of debt will decrease until it reaches the level $Y_{1}^{2}$. When a borrowing country has an initial income of $Y_{1}^{1}$, it is indifferent between investing everything in the DRS sector and repaying, investing everything in the DRS sector and defaulting, and investing in both sectors (where $\left.(1-n)\left(f^{\prime N}+1\right)=(1-z)\left(f^{\prime M}+1\right)\right)$ and defaulting. To put in another way, the income is just high enough such that the highest debt that the borrower can be trusted to repay allows 
for just enough funds to make the borrower indifferent between investing in just the DRS sector and investing mostly in the IRS sector and defaulting. Note that at this point, the value of repaying when investing in both sectors will be lower than when defaulting because at a given output level the punishment will be lower when funds are invested in the IRS sector. As initial incomes increase above $Y_{1}^{1}$, the borrowers needs less debt to have an incentive to invest in the IRS sector and default. While the borrower initially has more income to be extracted under default, if the borrower has an incentive to invest in the IRS sector, the fraction of the output that will be extracted will be less than the fraction that would be extracted when all investment is in the DRS sector (in this case we are comparing two different sectors, and it is possible to have $\left.\partial V^{R} / \partial Y_{1}<\partial V^{d} / \partial Y_{1}\right)$. Between initial incomes $Y_{1}^{1}$ and $Y_{1}^{2}$, the lender does not want the borrower to invest anything in the IRS sector because the borrower will not have an incentive to repay. Therefore, as incomes increase in this range, debt will decrease.

After the income level $Y_{1}^{2}$, initial income is positively related to debt. For a borrowing country who has an initial income of $Y_{1}^{2}$, it receives loans such that it is indifferent between investing all funds in the DRS sector and repaying, investing most funds in the IRS sector and repaying, and investing even more funds in the IRS sector and defaulting. Such an income and debt level was illustrated in Figures II.7a. and II.7b. As income increases from $Y_{1}^{2}$, utility from investing in both sectors will exceed utility from investing only in the DRS sector, regardless as to whether the borrower defaults or repays. Given that investment is in both sectors, when income increases, the value of repayment increases more than the value of default (under plausible parameters), and 
more debt will be allowed to the borrowers. As diminishing marginal returns set in, the punishment for default increases at a diminishing rate, so the equilibrium debt will increase at a diminishing rate.

Note that this relationship between initial income and debt supports a twin-peak world income distribution. The poor countries that can only get enough debt to invest in the sectors that exhibit diminishing returns will converge because the debt decreases between $Y_{1}^{1}$ and $Y_{1}^{2}$. Growth would then take off for those incomes above $Y_{1}^{2}$ because debt and income will be positively related. Divergence can then exist between a country with an initial income between $Y_{1}^{1}$ and $Y_{1}^{2}$, and a country with an initial income above $Y_{1}^{2}$

. Thus, initial income and sovereign debt can lead to twin peaks in world income if there is increasing returns with low punishment for default.

\section{Foreign Aid and Lending: Substitutes or Complements?}

From the relationship between initial income and debt, we can analogously examine the effectiveness of foreign aid. In some cases, foreign aid can decrease international lending, but in other cases, foreign aid can lead to more lending, as we can observe from the relationship between income and debt in Figure II.9. For incomes lower than $Y_{1}^{1}$, more foreign aid leads to more debt, until the sum of the foreign aid and initial income equals $Y_{1}^{1}$. For initial incomes above $Y_{1}^{1}$, the equilibrium debt is just enough to make the borrower indifferent between investing in the DRS sector and repaying and investing in both sectors and defaulting. Since the increasing-returns sector becomes more attractive as the amount of funds increase, for a given equilibrium debt level, a small amount of aid will give the borrower an incentive to invest in the IRS sector and 
default, instead of investing everything in the DRS sector and repaying. Therefore, for initial incomes between $Y_{1}^{1}$ and $Y_{1}^{2}$ in Figure II.9., the amount of debt will decrease if aid is increased and if the sum of the aid and initial income does not surpass $Y_{1}^{2}$. In fact, as illustrated in Figure II.9., if the initial income is between $Y_{1}^{1}$ and $Y_{1}^{2}$, aid will only increase debt if the aid is so large that it brings the income level above $Y_{1}^{2}$ to the point that it yields more loans.

For initial incomes greater than $Y_{1}^{2}$, an increase in foreign aid will increase the available funds for the borrower. At $Y_{1}^{2}$, the borrower receives just enough loans so that it is indifferent between investing all funds in the DRS sector and repaying, investing most funds in the IRS sector and repaying, and investing even more funds in the IRS sector and defaulting. Any foreign aid will give the borrower an incentive to invest in both sectors and repay, assuming $\partial \max V^{R} / \partial Y_{1}>\partial \max V^{d} / \partial Y_{1}$, which again is true under any plausible parameters. Therefore, if the initial income for the borrowing country is equal to or greater than $Y_{1}^{2}$, any amount of aid will increase the loans that the borrower can be trusted to repay.

In summary, foreign aid and foreign debt will be complements for very low income levels, between zero and $Y_{1}^{1}$, if the aid is small or if the aid is so large that it surpasses $Y_{1}^{2}$ enough to allow for more debt. In the same income range, foreign aid and foreign debt can be substitutes if the aid is enough (but not too much) to give the borrower an incentive to invest in the IRS sector and default. For example, as can be seen in Figure II.9., if the initial income is just below $Y_{1}^{1}$, then some aid, such as an 
amount that brings income to just below $Y_{1}^{2}$, will lead to less debt. For initial incomes between $Y_{1}^{1}$ and $Y_{1}^{2}$, foreign aid and foreign debt will be substitutes when the aid is small, but complements if the aid is large enough. For incomes above $Y_{1}^{2}$, foreign debt and foreign aid will be complements.

\section{II.V. Sector-Controlled Loans}

How would things change if the foreign lenders could control how their loans get invested? In many cases, we can imagine that lenders do have some control as to where their funds get invested. For instance, we can think of the lenders as the ones directly purchasing the physical capital, for which the borrowers then have to repay (or not), such as the case when someone is financing the purchase of a car. The borrower, therefore, cannot easily shift those funds to an alternative investment. In this model, with no capital flight or secret consumption, a sufficiently poor country with income below $Y_{1}^{1}$ will not gain if the lender can control where the sovereign invests the borrowed funds. A sufficiently poor country will get enough debt such that it is indifferent between repaying and defaulting after investing all funds in the DRS sector. It cannot get enough debt to have an incentive to invest some funds in the IRS sector, since the IRS sector has low initial returns and the value of defaulting will exceed the value of repayment if the borrower was given enough debt to overcome the initial low returns. The borrower could invest its initial income how it sees fit, but it would not get any higher utility from investing any of its own funds in the IRS sector. Therefore, for a very poor country, controlling which sector the funds go to will not help. 
If the funds are monitored for the borrowers who have an initial income between $Y_{1}^{1}$ and $Y_{1}^{2}$ in Figure II.9., the borrowers may or may not be better off than if none of the funds are monitored. Whether or not the borrower becomes better off, and how much it becomes better off, depends on the assumptions about the production functions and the assumptions about the way the loan is bargained. Again, when a borrowing country has an initial income of $Y_{1}^{1}$, it is indifferent between investing everything in the DRS sector and repaying, investing everything in the DRS sector and defaulting, and investing in both sectors (where $\left.(1-n)\left(f^{\prime N}+1\right)=(1-z)\left(f^{\prime M}+1\right)\right)$ and defaulting. For a borrower whose initial income level lies just above $Y_{1}^{1}$, if the funds were not monitored, the borrower would get a loan amount that would make it indifferent between investing everything in the DRS sector and repaying and investing in both sectors and defaulting, such as the case illustrated in Figures II.6a. and II.6b. If the loans were monitored, the result would only be different if the lender could give more loans and prevent the borrower from investing in both sectors and defaulting. The lender could do this if the debt is higher than the amount of funds that the borrower would have invested in the DRS sector under default. If the lender could force more funds in the DRS sector than the amount that the borrower would have invested under default, then the borrower may have an incentive to repay.

For example, in Figure II.10., the borrower will be allowed enough debt until the amount of debt equals the amount of investment in the DRS sector that the borrower would have invested if it defaulted and received the same utility as repayment under all investment in the DRS sector. In the figure, as we go from left to right, the amount of 
capital invested in the IRS sector increases from zero to $Y_{1}+D_{2}$. As we go from right to left, capital invested in the DRS sector increases from zero to $Y_{1}+D_{2}$. On the vertical axis, utility from defaulting and repaying is measured. The box is for a given income and debt level. We can see from the horizontal dotted line in the figure that if $K_{2}^{N^{*}}=D_{2}$ the utility from defaulting at that point equals the utility from repaying when all funds are invested in the DRS sector. If the debt was smaller than $K_{2}^{N^{*}}$ in Figure II.10. (keeping total investment fixed), the borrower could invest less in the DRS sector, more in the IRS sector, and achieve a higher utility from defaulting. If the debt was larger than $K_{2}^{N^{*}}$ in Figure II.10., the lender can allow even more funds since it could force those funds to be invested in the DRS sector, and the borrower would then have an incentive to repay. As debt increases, the curves shift up (and lengthen), with the value of default increasing more than the value of repayment at each given debt level. Therefore, at some debt level, the value of repayment will equal the value of default when all the funds are invested in the DRS sector. Once debt reaches such a threshold, controlling the sector in which the loans are invested will not help since default will be more attractive at each investment set that includes investment in the IRS sector.

For income levels above $Y_{1}^{2}$ in Figure II.9., just as for lower income levels, controlling which sectors the loan is invested in will be beneficial only if the loan is a large enough portion of the total funds invested when the IRS sector becomes attractive to invest in. As we will also see, the degree at which the borrower benefits will depend on how the loan is negotiated in the first place. Again, at $Y_{1}^{2}$, with no monitoring, the borrower receives just enough loans so that it is indifferent between investing all funds in 
the DRS sector and repaying, investing most funds in the IRS sector and repaying, and investing even more funds in the IRS sector and defaulting, as illustrated in Figures II.7a. and II.7b. For higher income levels than $Y_{1}^{2}$, without monitoring, the borrower receives just enough loans so that it is indifferent between investing most funds in the IRS sector and repaying and investing even more of its funds in the IRS sector and defaulting. Any more debt than equilibrium, without monitoring, will give the borrower an incentive to invest most funds in the IRS sector and default. If the loans are monitored, the lender may be able to prevent the borrower from investing too much in the IRS, and in doing so, allow even more loans to the borrower than if the loans were not monitored.

Suppose that the borrower has an initial income a little above $Y_{1}^{2}$, so that it is given enough debt to be indifferent between investing most funds in the IRS sector and repaying and investing even more funds in the IRS sector and defaulting (imagine a debt a little higher than shown in Figure II.7b.). If the lender could control more than the amount that the borrower was going to invest in the DRS sector without monitoring, then the lender can give more loans that will be repaid. It may turn out however, as will be shown, given that the DRS sector is more collateralized than the IRS sector, the lenders may want a bigger debt level than the borrower would like to obtain. The equilibrium debt level would then depend on how the loan is negotiated.

Take for example, Figures II.11a. and II.11b. In Figure II.11a., the borrower is given some loans, some are forced to be invested in the DRS sector, and the borrower invests the rest in the IRS sector. The horizontal line is where the value of repayment equals the value of repayment, and the amount of debt must be at least as large as the DRS investment in order for that point to be a possible contract. As we can see, if funds 
were not monitored, the borrower would invest more in the IRS sector and default. However, if the loans in Figure II.11a. exceeded the amount of DRS investment where the value of default equaled the value of repayment, the lenders can give more loans and force more of it in the DRS sector, as in Figure II.11b. Even though the borrowers can invest more from the additional loans, if it means that the lenders can make the investment go in the DRS sector, the borrowers may actually be worse off. The horizontal line shows the utility received when the debt is at the lower level in Figure II.11a., which is higher than when the debt is higher in Figure II.11b. If the lender could control a large amount of the funds, they may want to give more loans than the borrowers would prefer. The amount of loans, therefore, depends on how the loans are negotiated. If the lender could give the borrower an ultimatum, then the borrower would take the loans since it is better than nothing. If the borrower could negotiate, then the borrower may want to accept a lower amount of debt, be able to invest more of it in the more productive sector, and achieve a higher net output than with a larger loan. With a larger loan, the borrower will be forced to invest most of it in the less productive sector, which can be worse for the borrower than a smaller loan that is invested mostly in the IRS sector.

\section{II.VI. Conclusions}

The objective of this paper is to analyze the effects of increasing returns and collateral differences on a sovereign borrower. The purpose of this analysis is to help explain why poor countries may invest in less productive sectors than rich countries, give a reason why the world income distribution can have twin peaks, and explain the effectiveness of alternative policies to help increase investment and output in the poor 
countries. Many other papers have also used a two-sector economy to explain differences in economic growth, including the "Dutch disease" literature. This paper differs from those in that the mechanism which inhibits growth is initial income, sovereign risk, and collateral differences across sectors. Poor countries do not suffer from a resource curse in this model, but instead they heavily invest in natural resources because they do not have enough initial income and they cannot attain enough debt to invest in the sectors that have increasing returns. This paper argues that a main reason holding the borrower from investing in the more productive sector could be the lack of collateral in such sectors. Investments in infrastructure, research and development, education, and health may pay off handsomely if a large amount of funds are allocated to those sectors. However, international lenders may not be interested in loaning funds for such investments since a sovereign borrower may not be held accountable if they default after investing in those sectors. For instance, a lender may have a difficult time extracting a road or a school. However, if loans go towards investing in natural resources, a sector that a poor sovereign borrower may heavily export, the lender may find it easier to punish the borrower under default. Sectors such as natural resources or agriculture may have high initial returns, but those returns are diminishing as the resources become scarce.

The results from this paper suggest different policy implications for different income levels. For example, the poorest of the poor would benefit significantly from foreign aid, as it would also increase foreign lending because of the increase in collateral. However, the poorest countries would not benefit from perfect monitoring of investment in this model, since the borrower will only have an incentive to invest in the DRS sector regardless of whether or not the lenders can control where the funds go. For poor 
countries that have a little more income, some foreign aid may not significantly help because it may lead to fewer loans, since the borrower may have an incentive to invest less in the collateralized sector and more in the less-collateralized sector and default. At these income levels, policies that will improve monitoring of investment may help increase investment and output since the lenders may be able to prevent the borrower from investing in sectors that are less collateralized, and as a result the lender will give more loans.

For the countries that have enough income and debt to invest in the IRS sector and repay, they will be significantly helped by foreign aid because it will increase collateral and allow them to take advantage of increasing returns. Improving monitoring of investment could increase investment, but it could also lead to excess lending. For instance, if the lenders had control over which sectors the funds were invested in, they may require all loans go in the DRS sector, while the borrower may be better off if they received less loans but could invest a large portion of the funds in the IRS sector.

At all income levels, as in previous studies, increasing punishment for default will help the borrower. However, the significant difference in this paper is that it shows how an increase in punishment for default from output in the low productivity sector may actually decrease investment and output in the that sector, while increasing investment and output in the high productivity sector. Since the borrower will always want to invest at least some funds in the DRS sector, increasing punishment for default in that sector will increase the collateral for any investment portfolio that includes investment in the DRS sector. Before an increase in punishment in the diminishing-returns sector, a borrower may have not been allowed enough debt to have an incentive to invest in a 
portfolio that included mostly investment in the IRS sector, with little investment in the DRS sector. However, an increase in punishment in the DRS sector may give the borrower an incentive to invest in mostly in the IRS sector and repay since the collateral from the investment in the DRS sector is high enough.

In summary, this paper helps explain how some poor countries can be inherently stuck investing in less productive sectors because of sovereign debt problems. The paper also discusses the effects of possible policies that can be taken to alleviate the problems with sovereign debt and increase investment and output in the poor countries. However, the results of this paper suggest that countries at different income levels will be affected differently from the same policies. 
Figure II.1. Production Function of the IRS and the DRS Sector

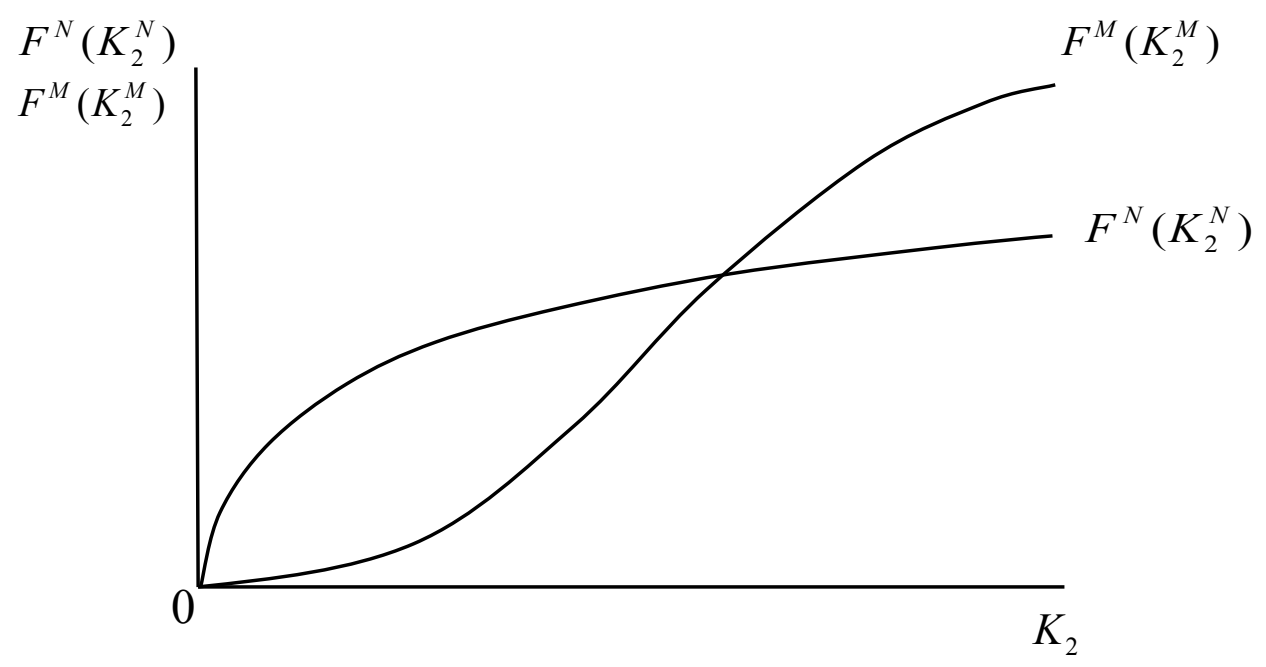

Notes: Output in the diminishing-returns sector (DRS), $F^{N}\left(K_{2}^{N}\right)$, or natural resource sector, increases as investment in that sector increases, but at a diminishing rate. The initial marginal product is high, but it goes down as the resources are extracted. Output in the increasing-returns sector (IRS), $F^{M}\left(K_{2}^{M}\right)$, or manufacturing sector, has a low marginal product at low levels of investment, but output initially increases at an increasing rate. At high levels of investment, the IRS sector is more productive than the DRS sector. 
Figure II.2: Equilibrium Investment Composition given an Income and Debt Level

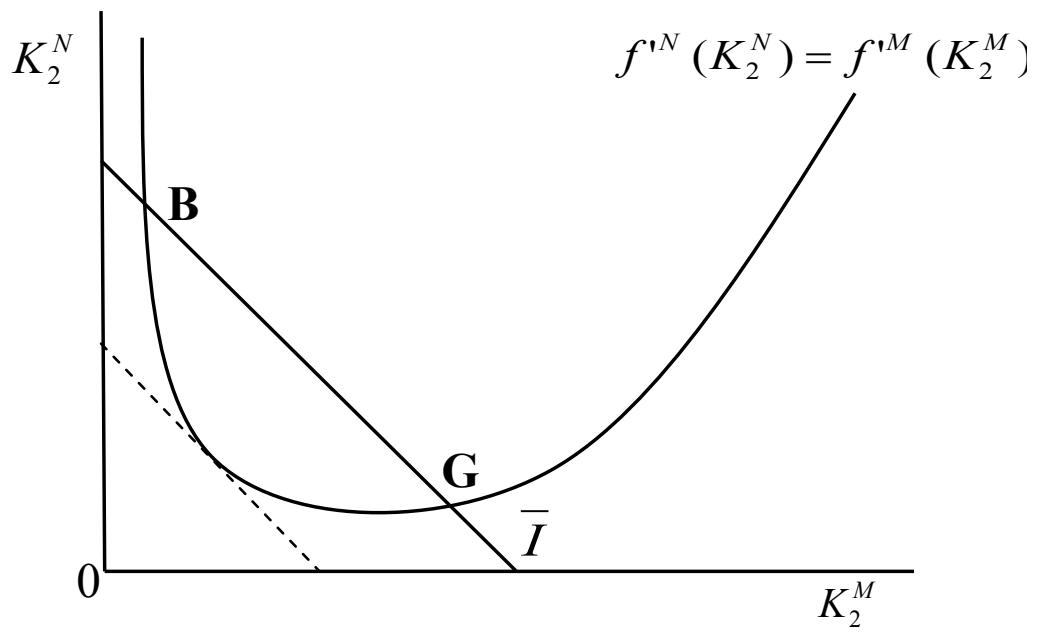

Notes: Given an initial income and a debt level, the borrower can invest their funds in the IRS sector, $K_{2}^{M}$, or DRS sector, $K_{2}^{N}$, and the possible combination is represented by $\bar{I}$. If the fraction of income extracted under default is the same across sectors, and the borrower has enough income and debt, the optimal investment will equalize the marginal products across sectors, $f^{\prime N}\left(K_{2}^{N}\right)=f^{\prime M}\left(K_{2}^{M}\right)$. Points B and $\mathrm{G}$ are where all funds are invested and the marginal products are equalized. 
Figures II.3a. and II.3b. Equilibrium Debt and Investment Composition Levels for a Sufficiently Poor Country

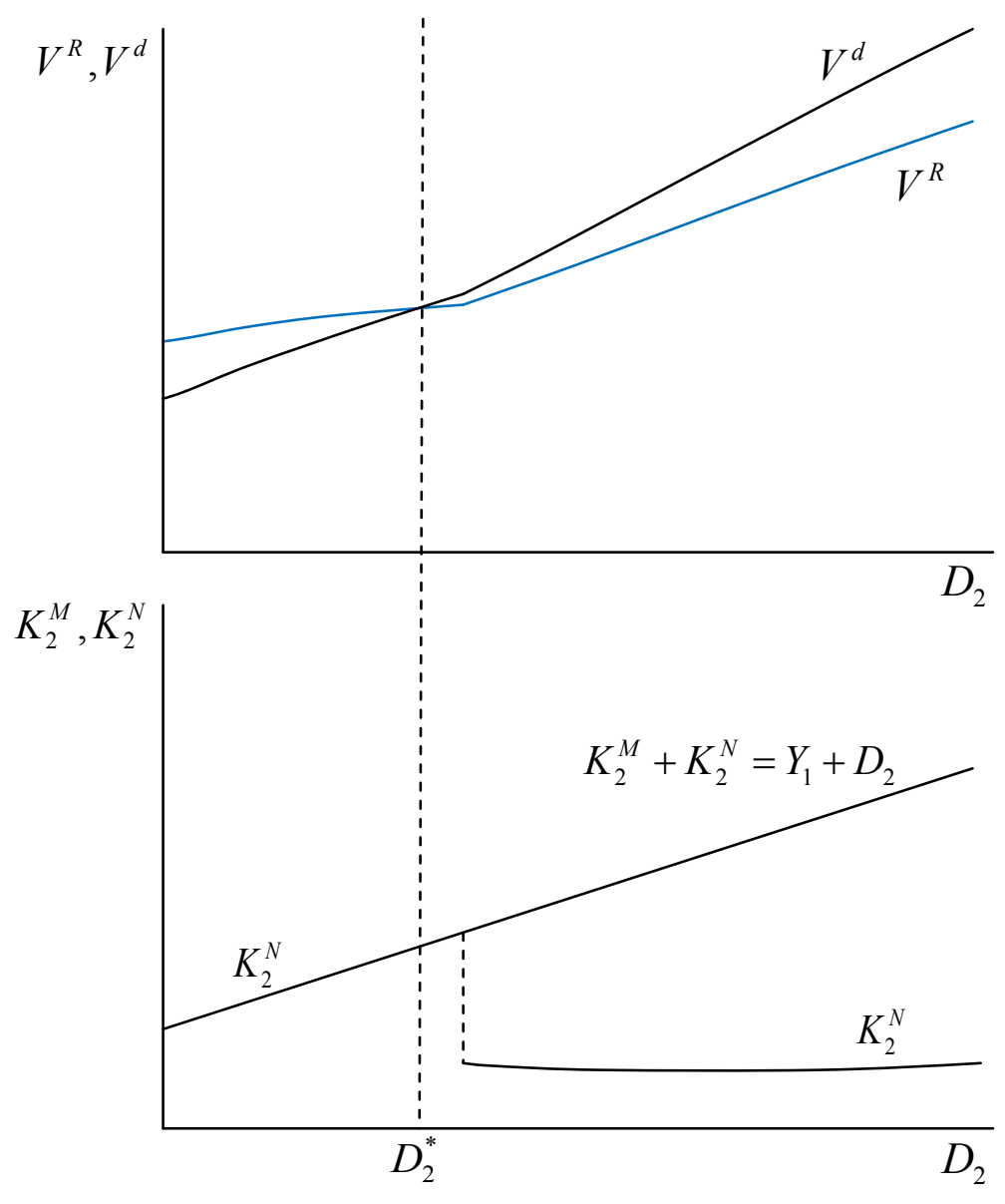

Notes: In Figure II.3a., the maximum value of default and the maximum value of repayment are given as a function of debt for a given initial income level. Figure II.3b. illustrates the relationship between debt and the composition of investment. 
Figures II.4a. and II.4b. Equilibrium Debt and Investment Composition Levels for a Threshold Income Level

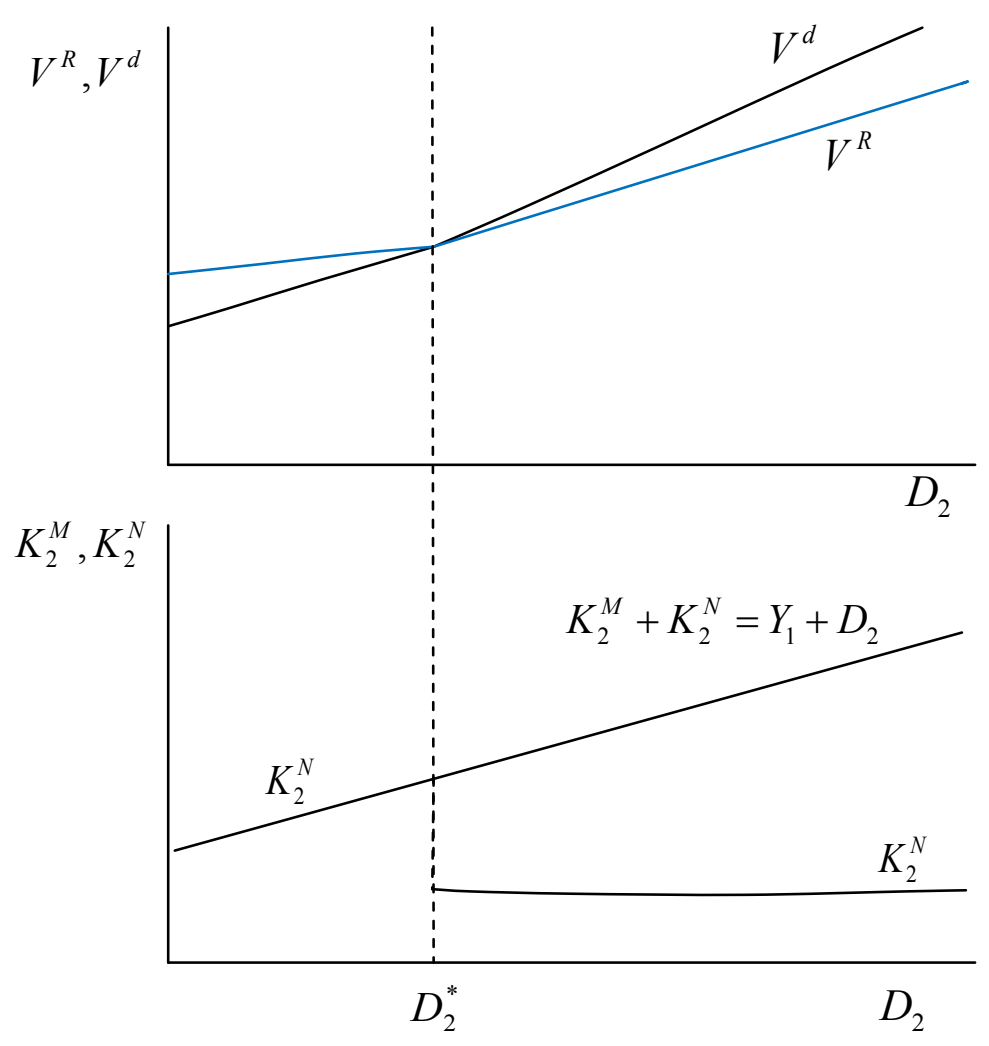

Notes: In Figure II.4a., the maximum value of default and the maximum value of repayment are given as a function of debt for a given initial income level. Figure II.4b. illustrates the relationship between debt and the composition of investment. 
Figures II.5a. and II.5b. Equilibrium Debt and Investment Composition Levels for a Sufficiently High Income Level

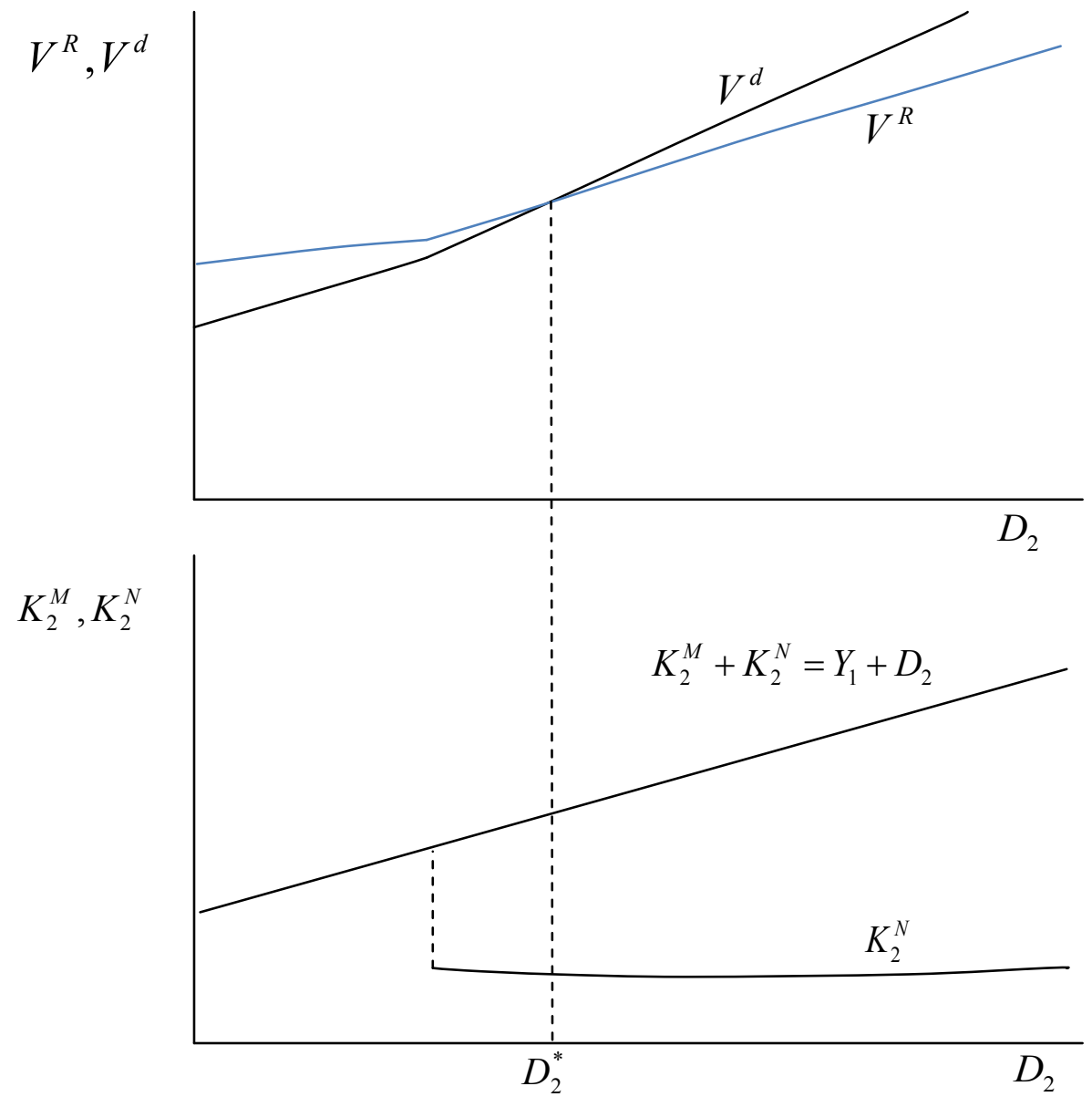

Notes: In Figure II.5a., the maximum value of default and the maximum value of repayment are given as a function of debt for a given initial income level. Figure II.5b. illustrates the relationship between debt and the composition of investment. 
Figures II.6a. and II.6b. Equilibrium Debt and Investment Composition Levels for a Poor Country under Collateral Differences across Sectors

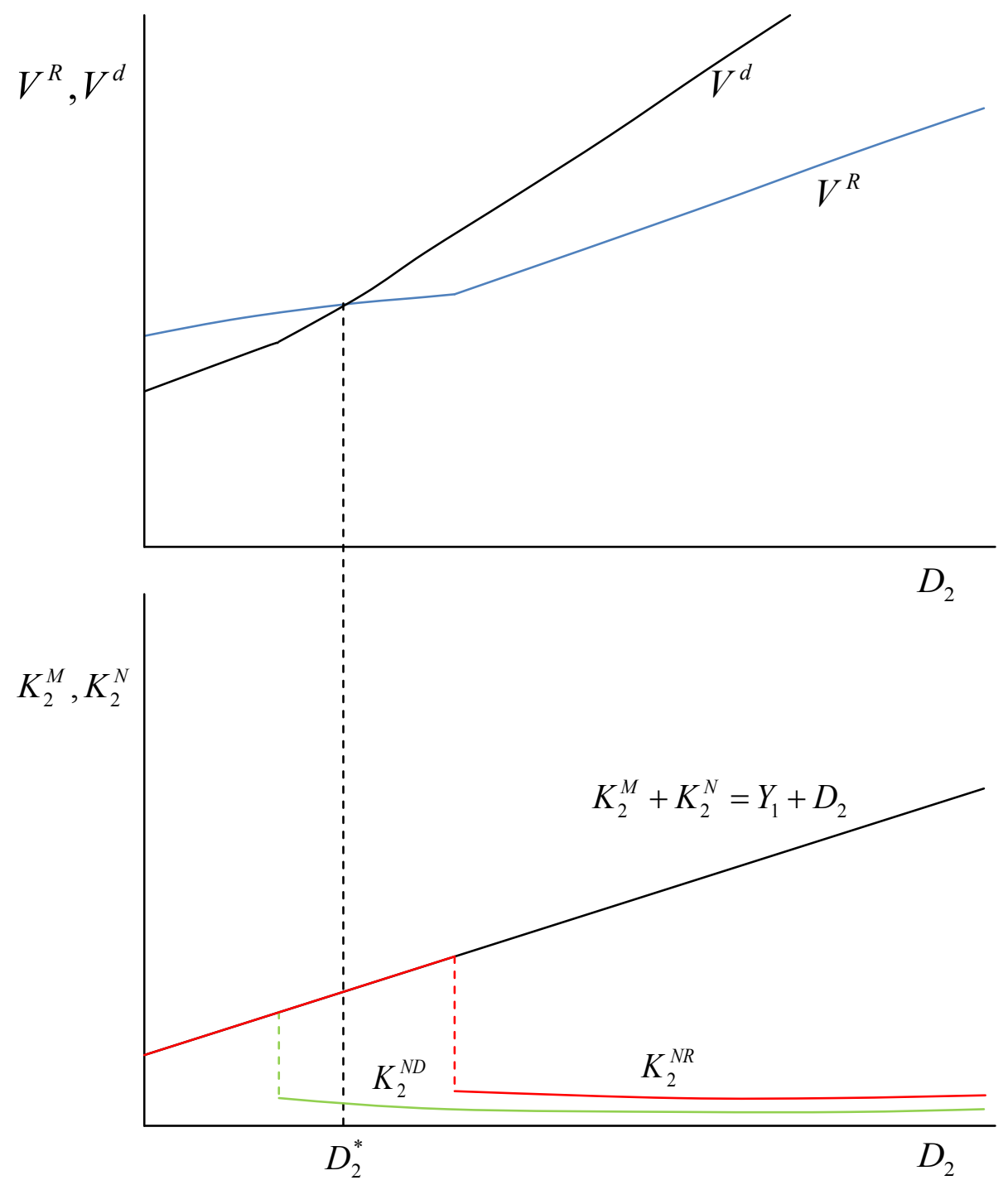

Notes: In Figure II.6a., the maximum value of default and the maximum value of repayment are given as a function of debt for a given initial income level. Figure II.6b. illustrates the relationship between debt and the composition of investment. 
Figures II.7a. and II.7b. Equilibrium Debt and Investment Composition Levels for a Threshold Country under Collateral Differences across Sectors

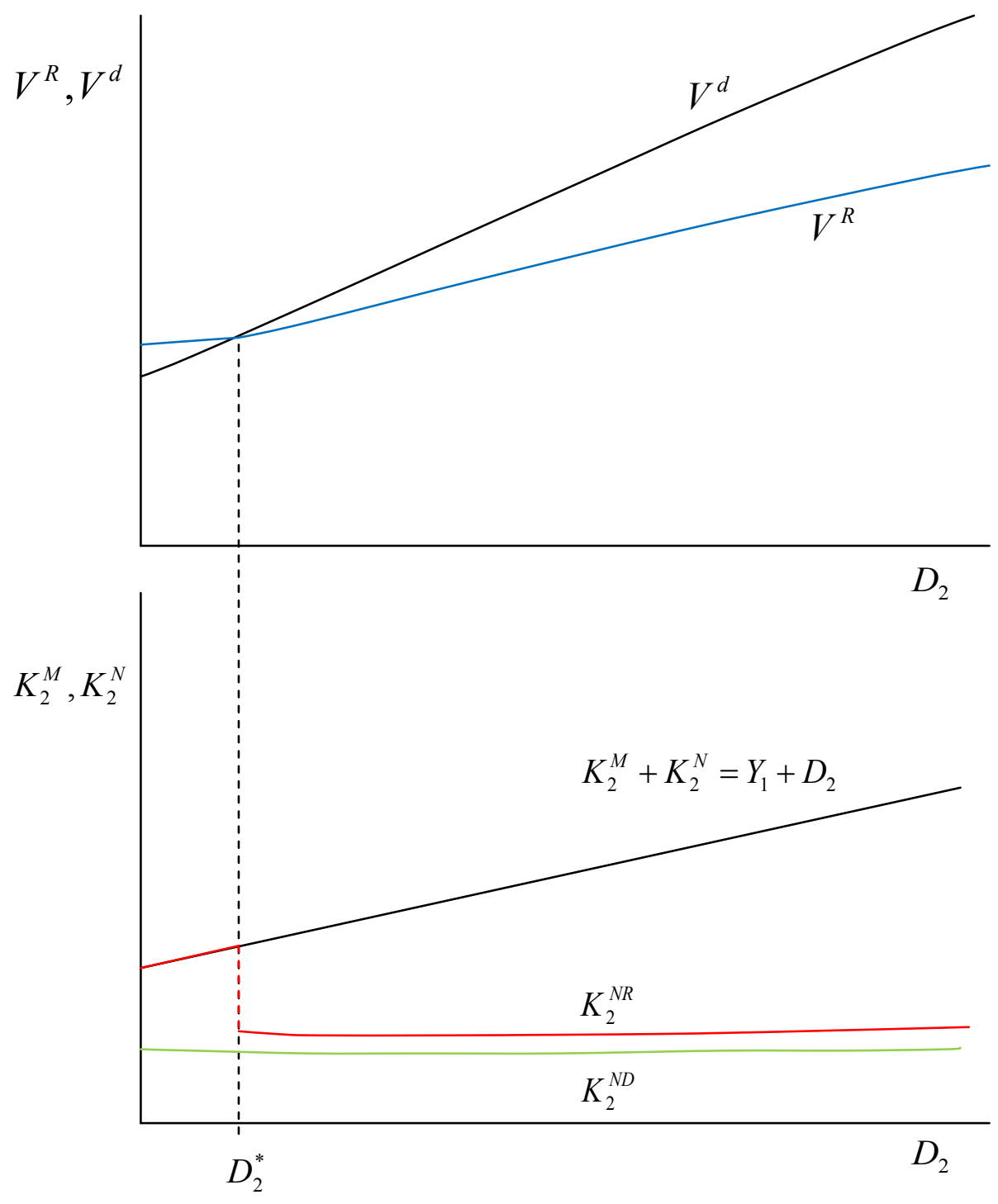

Notes: In Figure II.7a., the maximum value of default and the maximum value of repayment are given as a function of debt for a given initial income level. Figure II.7b. illustrates the relationship between debt and the composition of investment. 
Figure II.8. Equilibrium Debt after an Increase in Punishment in the Decreasing-Returns Sector

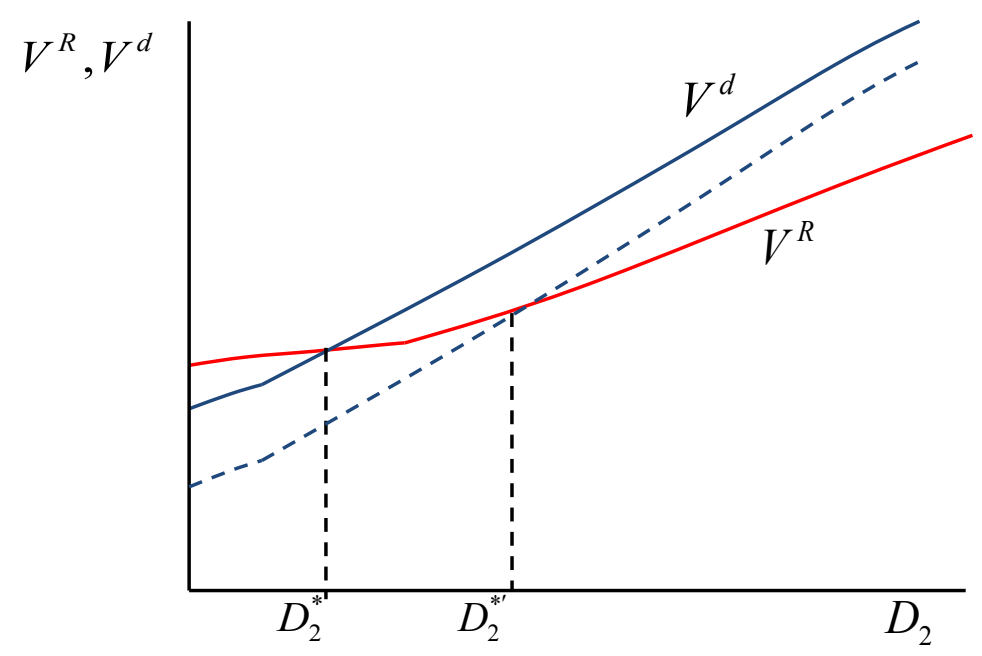

Notes: In Figure II.8., the value of defaulting decreases because of the increase in punishment from DRS-sector output. Since an optimal investment portfolio always includes some DRS investment (because of the initial high returns), every possible investment by the borrower can be punished more severely. More debt is allowed, and the borrower in this case now has an incentive to invest in both sectors. 
Figure II.9. Income and Debt when Decreasing-Returns Sector is more Collateralized

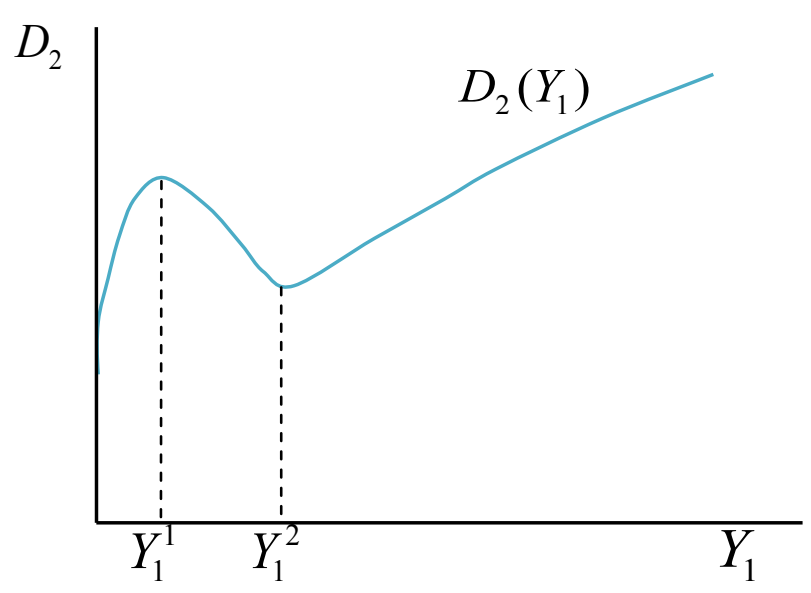

Notes: Figure II.9. shows the relationship between income and debt when the diminishing-returns sector is more collateralized than the increasing-returns sector. As income increases from zero to $Y_{1}^{1}$, debt increases because of the increase in the collateral. As income surpasses $Y_{1}^{1}$, debt decreases because the lender does not want the borrower to invest in the less-collateralized IRS sector and default. As income surpasses $Y_{1}^{2}$, debt increases as the borrower is given debt to invest in the IRS, and the high returns increases punishment enough to support loans. 
Figure II.10. Investment Composition with the Equilibrium Debt Level under Sector-Controlled Loans

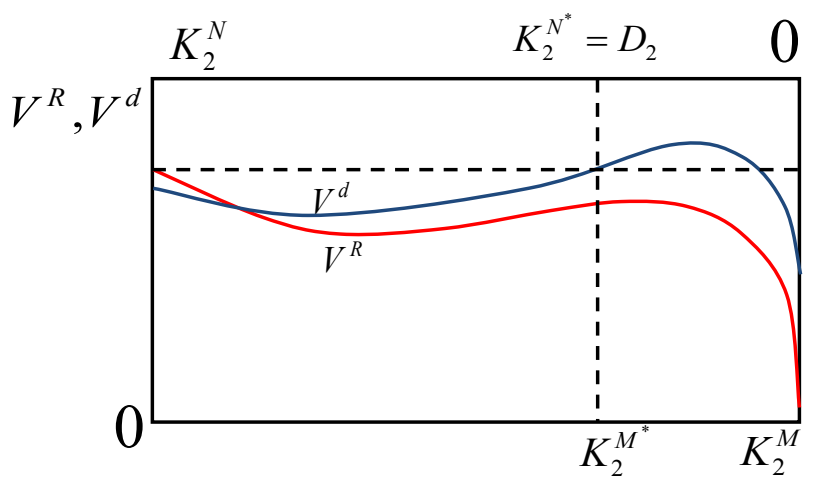

Notes: Figure II.10. shows the value from default and repayment given an initial income and sector-controlled loans. Looking at the figure, we can see that the borrower would prefer to invest more than $K_{2}^{M^{*}}$ in the IRS sector and default. However, if the lender could force $K_{2}^{N^{*}}$ of the funds to be in the DRS sector, then the borrower will not have an incentive to default. If $K_{2}^{N^{*}}=D_{2}$, then we are at equilibrium. If the lender gave more loans, the borrower would default because the value from defaulting will increase more than the value from repayment, under reasonable parameters (and the figure will expand). If debt is less than the investment in the DRS sector, then the lenders are forgoing profit. 
Figure II.11a. Optimal Debt for the Borrower when the Lenders can Control the Sector where the Loans are Invested
Figure II.11b. Optimal Investment for the Lenders when they can Control the Sector where the Loans are Invested

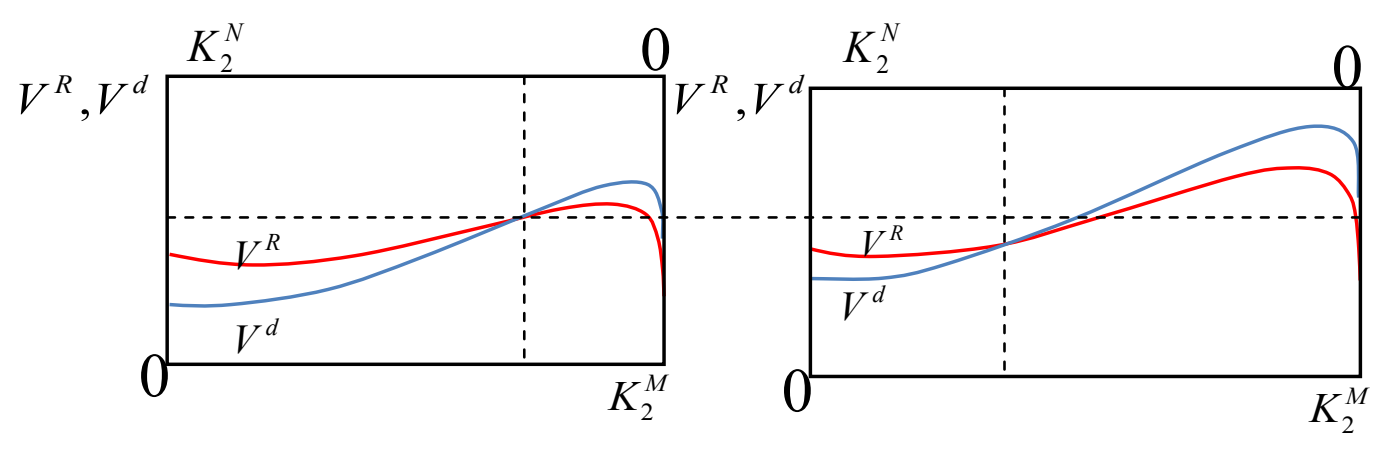

Notes: Given the same parameters, Figure II.11a. is an example of an optimal debt contract for a borrower if the lender can control where the loans are invested, while Figure I.11b. is an example of an optimal debt contract for a lender. In Figure II.11a., the borrower is given funds such that they are allowed to invest heavily in the IRS sector, where the value of default equals the value of repayment. However, in Figure II.11a., if the loans exceed the amount of capital invested in the DRS sector, the lender may give more loans that will be repaid (see Figure II.10. for explanation).

As the debt increases, both the value of default and the value of repayment increases, with the value of default increasing more at each investment set. Since the DRS sector is more collateralized, as debt increases, the value of repayment will exceed the value of default only if most of the investment is in the DRS sector. If the debt equals the amount invested in the DRS sector where the curves intersect in Figure II.11b., the lenders have maxed out the amount of loans they can give that will be repaid. In this example, the borrower was better off in Figure II.11a., where they received less loans than in Figure II.11b., because in Figure II.11a., they were allowed to invest more heavily in the IRS sector than in Figure II.11b. 


\section{INCREASING RETURNS, INSTITUTIONS, AND CAPITAL FLOWS III.I. Introduction}

Poor, capital scarce countries should attract more capital flows than rich, capital abundant countries under the assumption of diminishing marginal productivity of capital. However, the data clearly show that capital predominantly flows to the rich countries. This phenomenon, which is sometimes referred to as the Lucas Paradox (Lucas 1990), has generated many theoretical explanations. Some studies have tried to explain this phenomenon by pointing to differences across countries that could affect the productivity of capital, such as differences in institutions and human capital, while other studies have focused on other factors that may restrict international capital flows, such as asymmetric information, sovereign risk, and transaction costs. While there are numerous theoretical explanations, there are a relatively few number of empirical studies of international capital flows and the macroeconomic fundamentals suggested by the theories.

Of particular interest in this paper, will be the role of initial capital and institutions in attracting capital flows. This paper will follow a similar procedure to that of Alfaro, Kalemli-Ozcan, and Volosovych (2008), but different variables will be used as a measure of institutional quality. As will be shown, institutions play a key role in attracting capital flows, but this finding does not resolve the Lucas Paradox. My results are in contrast to the study by Alfaro, Kalemli-Ozcan, and Volosovych (referred to as AKV for the rest of the paper), which concludes that initial capital does not affect capital inflows. In fact, I show that initial capital is positively correlated with capital inflows, even when controlling for institutions and other factors that can influence capital inflows. In addition, and in contrast to $\mathrm{AKV}$ and other studies, I compare a sample of poor 
countries with a sample of rich countries, and I find that the main determinants of capital flows for poor countries are different from the main determinants of capital flows for the rich countries.

To decide which variables to include as the fundamental determinants of capital flows, I follow AKV and look at the different theories of why the data do not support the standard models of economic growth. In a typical economic growth model, as in Solow (1956), if countries operate with the same technology with constant returns, with the individual marginal products of capital and labor diminishing, the countries with less capital (poor countries) will get a higher marginal return to capital. Following this logic, if individuals seek to get the highest return on their capital, they would invest in the poorest countries. Obviously, the data suggest there is something wrong with these models or assumptions, since capital has predominately flowed to rich, capital abundant countries. I will now briefly discuss a few of the possible remedies to the standard model suggested by the theories, and how I will incorporate them in my estimation.

One possible reason why capital has not flowed to the poor countries is differences in human capital. As discussed in the classic work by Lucas (1990), capital may not flow to poor countries if the labor force, for a given amount of capital, is less productive in the poor countries. In addition, human capital may be subject to externalities, where the productivity of one worker may influence the productivity of another worker. To account for differences in human capital, I include a measurement of schooling as an explanatory variable. Since I am including initial Gross Domestic Product (GDP) also as an explanatory variable, which is highly correlated with schooling, 
one would think that the coefficient on initial GDP would diminish, but as will be shown, the significance of initial GDP's impact on capital flows remains strong.

Poor institutions in developing countries may also deter capital flows. According to Douglass North (1994), "Institutions are the humanly devised constraints that structure human interaction. They are made up of formal constraints (e.g., rules, laws, constitutions), informal constraints (e.g., norms of behavior, conventions, self-imposed codes of conduct), and their enforcement characteristics. Together they define the incentive structure of societies and specifically economies." As will be detailed later, I use numerous measures of institutional quality to account for different institutions across countries. Institutional quality is also highly correlated with initial GDP, which again one would expect to diminish the significance of initial GDP's impact on capital flows, but as we will see from the regression results, the significance of GDP is robust in the World sample. I will also instrument for institutions using log European settler mortality, made famous by Acemoglu, Johnson, and Robinson (2001), but we will see that initial GDP remains significant.

Along with different institutions, international investment suffers from sovereign risk and asymmetric information. If investing internationally in a foreign country, a typical investor is not only less familiar with the foreign country's environment than with his own, including its rules and regulations, but he may not have a strong recourse if the sovereign nation defaults or refuses to follow through on a contract. In a classic textbook model of sovereign debt, as in Obstfeld and Rogoff (1996), a poor sovereign borrower may not be able to obtain enough loans to invest efficiently since it cannot commit to repay the loans. Reputation may also play a key role, and some investors may shy away 
from countries who have defaulted in the past (see Tomz, 2007; Reinhart and Rogoff, 2004; Bulow and Rogoff, 1989; and Eaton and Gersovitz, 1981). Theoretically, a poor country may not have an incentive to efficiently invest foreign loans in the domestic economy, but instead secretly buy risk-free securities (i.e., capital flight), default on the loans, and avoid the punishment by feigning bankruptcy, as described in Gertler and Rogoff (1990). Most of these explanations rely on weak contract enforcement, which is incorporated in the institutional composite variables used in this empirical investigation.

Geography and infrastructure may also help explain the lack of international capital flows to poor countries. The return on capital may be lower when accounting for the cost of transport (also see Obstfeld and Rogoff (2000), who relate transport and trade costs in goods to the lack of capital flows). Since infrastructure and geographical location may play a key role in productivity and capital flows, they will be included as explanatory variables in the regression. However, as with education and institutions, infrastructure is highly correlated with initial GDP, which one would think would diminish the significance of the impact of initial GDP on capital flows, but as we will see, the coefficient is still significant in the World sample when including all of the above explanatory variables.

The above reasons may not sufficiently explain the lack of capital flows to poor countries. Including infrastructure, institutions, and education as explanatory variables may pick up some externalities associated with being developed, but it may not entirely pick up the source of increasing returns. Several studies suggest learning-by-doing and industrialization as a source of increasing returns, as in Romer (1986), Krugman (1987), and Matsuyama (1992). Controlling for education may not fully pick up human capital 
differences and advantages of producing in a developed market. However, it may be possible to pick up the effect of industrialization, or moving out of an agricultural economy. To control for industrialization, I will include as an explanatory variable the percentage of GDP that comes from agriculture. The surprising result, as I will show, is that initial GDP still has a significant impact on capital flows in the World sample, even when controlling industrialization and the previously mentioned variables.

The explanation for the persistence of increasing returns may be simple. Economies of scale may inherently exist in the most productive sectors, as I described in chapter II. Countries with enough capital may invest in sectors with high fixed costs (or low initial returns), that may yield a better return than other sectors that only require a small investment. For example, investing in infrastructure or manufacturing may only be profitable if a large amount of capital is used, while agriculture or natural resource extraction may require less initial capital to be profitable. If sovereign risk and asymmetric information constrain capital flows, initial capital may play a key role in attracting foreign investment. A country with a high initial capital endowment may attract more capital flows than a country with a low initial capital, since the poor country would have to borrow too much (to be worth the risk) to invest in the productive sectors. To see this clearly, I will show that increasing returns may be explained away if we divide the sample and compare the rich countries with the poor countries. Within the poor group, there may be no increasing returns; within the rich group, there may be no increasing returns; but within the World sample, increasing returns exists as countries move to more productive sectors with higher income levels. 
In the next section, I show the estimates from Ordinary Least Squares (OLS). In Section III., I discuss endogeneity, and I show the results from two-stage least squares. I summarize the results in Section IV., and I discuss the policy implications. The data is described in the appendix.

\section{III.II. Data and Ordinary Least Squares}

\section{Capital Flows and initial GDP}

The dependent variable is capital inflows. For the measurement of capital inflows, I use foreign direct investment (FDI) and portfolio equity investment from the International Monetary Fund's International Financial Statistics (IFS). If a foreign investor purchases 10 percent or more of the firm's securities, it is considered foreign direct investment; otherwise, it is considered portfolio equity investment. I do not include debt flows since they may include government decisions, and they may not reflect market decisions. Similar to the procedure used by AKV, I take the annual average of FDI plus portfolio investment from 1970 to 2008 (or most recent year).

Figure III.1. displays the relationship between capital inflows and initial GDP, without controlling for any other variables. As a measurement of initial capital, I use real GDP per capita from 1970 (Penn World Tables). The relationship is positive and significant. For a country that has 100 dollars more in initial income per capita (1996 base year), it receives on average 4.5 dollars more in annual capital inflows per capita. Note that the levels of GDP are used, not log GDP, which was used in the study by AKV. Log GDP does not fit the data as well as the levels of GDP, which may be a contributing factor for why AKV found the coefficient on log GDP insignificant when controlling for institutional quality. Model 1A from Table III.1 displays the results from the regression 
shown in Figure III.1. Initial GDP is highly correlated with capital inflows, as shown by the adjusted R-squared of 0.64 .

The relationship between initial GDP and capital inflows is not a simple linear relationship. We can see from Figure III.1. that the variance increases as initial GDP increases until GDP nears $\$ 5000$, and then the variance remains relatively stable. ${ }^{4}$ Upon closer inspection, initial GDP and capital flows seem to be weakly correlated until initial GDP surpasses \$2500, and then capital flows and initial GDP seem to be strongly correlated when initial GDP is greater than $\$ 2500$. Conveniently, this break point occurs around the median initial income level, which allows enough observations on each side to compare each half with separate regressions. ${ }^{5}$

Figures III.2a. and II.2b. show the dramatic difference in the relationship between the initial income and capital inflows between the two groups. Table III.1. shows the correlation between initial GDP and capital inflows for each group in Models 2A and 3A, before controlling for other variables that might affect capital inflows. 53 countries are in the poorest half and 54 countries are in the richest half. For the poorest half, the coefficient for initial GDP is positive and significant, but it is very weak. For every additional $\$ 100$ in initial income, a "poor" country attracts an additional $\$ 0.94$ in annual capital flows. Initial GDP does not explain much of the variation in capital inflows for the poor countries, as shown with an adjusted R-squared of 0.077 .

\footnotetext{
${ }^{4}$ Correcting for heteroskedasticity does not change the significance of any of the estimates, so the uncorrected OLS estimates are shown for ease of replicability.

${ }^{5}$ Shifting the breakpoint a little doesn't make much difference, but a significant change would make the number of observations too low to compare each group, especially when introducing log settler mortality as an instrument.
} 
For the richest half, the story is very different. With initial GDP as the only explanatory variable, it explains about half of the variation in the capital inflows. For every additional $\$ 100$ in initial GDP, a "rich" country receives an additional $\$ 4.70$ in capital inflows. A country in the rich group receives nearly five times more capital flows than a country in the poor group for every additional $\$ 100$ in initial GDP. Figure III.3. gives us another perspective on the difference between the two groups. For each group, a quadratic equation is estimated. From Figure III.3., we can see the sharp distinction from the two groups. Note that the concave shapes do not represent diminishing marginal productivity of capital, since that would occur if the slopes were negative. However, we can see that the positive, or increasing returns, start to decline as initial GDP increases, especially for the poorest group.

\section{Explaining Increasing Returns}

According to previous theories, increasing returns, or North to North capital flows, can be explained by controlling for other variables. In the study by AKV, they conclude that institutions can eliminate this paradox. As a measure of Institutions, I use the data set from the Economic Freedom of the World 2009 Report (Gwartney and Lawson 2009). In the study by AKV, they use a measurement of institutional quality for the years 1984 to 2000 from the International Country Risk Guide (ICRG), The PRS Group. I argue that the data from the Freedom Report have a few advantages over the ICRG. One advantage is that the Freedom Report dates back to 1970 instead of 1984. Another advantage is that each component, generally speaking, is a measurement of economic freedom (or lack of restrictions or interference from government), which is not necessarily derived from being a developed or rich country. Therefore, it may be 
possible to extract more independent effects from initial GDP and institutions. Measurements of risk or institutional quality from the ICRG may be partially derived from the development of the country, and it may be more difficult to separate the independent effects from initial GDP and institutions.

As a starting point, similar to $\mathrm{AKV}$, I use a composite variable of institutions from 1970 to 2008 (or most recent year). Institutional variables are rated from 0 to 10 , where 10 is the most free, least restrictive, or least interfered with by the government. The composite variable of institutions is an average of the other institutional variables, which includes measures such as government size and taxes, property rights, inflation, tariffs, and regulations. The appendix lists the components of each institutional variable. ${ }^{6}$ Table III.2., Model 1B shows the regression with only initial GDP and institutions as the explanatory variables. The coefficient on initial GDP is significant at the $1 \%$ level, but the coefficient on institutions is not significant. Possibly, the insignificant coefficient on institutions could exist because of multicollinearity (which I also examine later), so in Model 2B I take out initial GDP and leave only institutions as the explanatory variable. Now, the coefficient on the institutions variable is significant at the $1 \%$ level, where an increase of 1 point on the $0-10$ scale is associated with an increase of $\$ 151$ of annual capital flows per capita. Using only the composite (average) variable for institutions, we can see that it does not explain as much of the variation of capital inflows as with the regression with initial GDP as the only explanatory variable. Of course, it is possible that the exclusion of other explanatory variables has biased the results, so I will now include

\footnotetext{
${ }^{6}$ For a complete description of how each component was constructed, please see the appendix of the Economic Freedom of the World Report.
} 
other variables suggested by the theory, and we will see that the coefficients on both institutions and initial GDP remain similar to the results in Model 1B.

As discussed in the theory, human capital may play a key role in increasing the marginal productivity of capital and attracting capital flows. To pick up some of the effects of human capital on capital flows, I include average years of total schooling for aged 25 and older from 1970 to 2000, obtained from Barro and Lee (2000). Infrastructure may also be essential to explaining increasing returns, since it may make capital more productive. To control for different infrastructure across countries, I use average annual percentage of roads that are paved from 1990 to 2008 (World Bank, World Development Indicators). ${ }^{7}$ As an indicator of transportation costs (besides infrastructure), I borrow variables from Gallup and Sachs (1999), such as being landlocked (not in Europe) and air distance from the capital-goods-supplying regions: the U.S., Western Europe, and Japan (specifically, the distance from the country's capital city to New York, Rotterdam, or Tokyo). As mentioned earlier, the marginal productivity of capital can be higher in countries that are industrialized than in those countries that rely heavily on natural resources or agriculture. Therefore, I include average agriculture production (\% of GDP) from 1970 to 2008 as an explanatory variable (World Bank, World Development Indicators).

Table III.2., Model 3B shows the regression results from including the explanatory variables suggested by the theory. The coefficient on initial GDP is positive and significant, and it has not significantly changed from Model 1B, which included

\footnotetext{
${ }^{7}$ Ideally, it would be better if the data on percentage of roads paved were available before 1990, but it is probably safe to assume that the relative differences across nations in infrastructure between 1990-2008 is approximately the same as it was 20 years prior.
} 
institutions as the only other explanatory variable. An additional $\$ 100$ in initial GDP is associated with an increase of $\$ 3.20$ in capital inflows, even after controlling for the additional variables. The coefficient on institutions has remained nearly the same from Model 1B, and it remains insignificant. Besides initial GDP, the only other variable with a significant coefficient is Distance, which has the expected negative sign. It is possible that some of the other variables are important but correlated with other covariates, diminishing the significance of that variable. Multiple regressions can show that this is not a large problem. However, we can compare the adjusted R-squared in Model 1B or Model 1A to Model 3B to see that there is only an improvement of 0.04 , which means that including all of the additional variables besides initial GDP explains only a small additional amount of the variation in capital flows.

\section{Decomposition of Institutional Variables}

Using a composite index that includes all the institutional variables, as in the study by AKV, may not be the proper approach. Although most of the institution variables are correlated with each other, some institutional variables may have a different effect on capital flows than other institutional variables. If this is the case, as we will see that it is, a composite index that includes all of the institutional variables may be a misleading measurement of institutional quality. In Table III.3., Model 1C, the regression includes initial GDP and the individual components (or smaller composites) of the general composite index of institutions. Initial GDP is still positive and significant at the $1 \%$ level. However, now we see that the variable labeled Property Rights and Legal Structure and the variable labeled Government Size and Taxes are significantly correlated with capital inflows. An increase in one point (0-10 scale) in Property Rights and Legal 
Structure is associated with $\$ 56.50$ more annual capital inflows per capita. Surprisingly, an increase in one point in Government Size and Taxes, which means a smaller government and lower taxes, leads to $\$ 29.80$ less capital inflows per capita.

In Model 2C from Table III.3., the other explanatory variables are added to the regression. ${ }^{8}$ Initial GDP remains positive and significant at the $1 \%$ level. The signs for the coefficients for Property Rights and Legal (positive) and Government Size and Taxes (negative) have the same sign as in Model 1C. When controlling for the other factors that affect capital flows, the coefficient on Business Regulations is also positive and significant. For every one point increase (0-10 scale) in Business Regulations, which means less regulations or less government interference, annual capital inflows per capita increases by $\$ 31.80$. After controlling for the components of institutions, location still has a significant important impact on capital inflows, as we can see by the negative and significant coefficient on the Distance variable.

From Model 2C, we can see that all of the institutional variables have a positive coefficient, except for Government Size and Taxes. Since the institutional variables are also correlated with each other, in Model 3C I included only the variables with a significant coefficient from Model 2C. We can see in Model 3C that the coefficients are almost identical to those in Model 2C. The model explains most of the variation in capital inflows, as we can see from adjusted R-squared value of 0.775 .

\footnotetext{
${ }^{8}$ I excluded schooling here because it is both insignificant and highly correlated with property rights, making the coefficient on property rights insignificant (barely). If replacing property rights with schooling, the coefficient on schooling is still insignificant. In order to prevent misleading results of the individual effects of the components of the institution composite variable, I exclude schooling in this model, but bring it back in the later regressions.
} 
The purpose of these estimates has been to explain the phenomenon of increasing returns, or lack of capital flows to poor countries. However, the persistence of a positive and significant coefficient on initial GDP per capita shows that the standard theory and the leading remedies to the standard theory have not fully explained the paradox. Including institutional variables and location have improved the standard model, but in contrast to the study by AKV, the effect of initial GDP remains strong when controlling for these factors. On the other hand, we have seen earlier that it may be inappropriate to group both poor and rich countries together, since initial GDP and capital inflows may have a different relationship in each group. Therefore, I will now compare the determinants of capital flows for the "poor" countries and the "rich" countries in separate regressions.

\section{"Rich" vs. "Poor" Countries}

We have seen in Figures III.2. and III.3. that there appears to be a break point around the median income level, where initial GDP and capital inflows go from having a weak relationship to a strong, positive relationship. If we separate the sample into two different regressions around the median income level, we can get an idea of the differences between the two groups. Table III.4. compares the regression from World sample to the regressions of the divided sample. Because of the smaller sample sizes, and to compare with two-stage least squares, I create a composite of institutions that is an average of all of the institutional components except for Government Size and Taxes. From the previous table in Model $2 \mathrm{C}$, we see that the coefficients of all of the institutional variables have a positive sign except for Government Size and Taxes. Therefore, I combine the variables with the same sign, and it will not suffer from the 
problem of the total composite variable, which has components that work in opposite direction.

In Model 1D from Table III.4., initial GDP, institutions, government size and taxes, and distance significantly influence capital inflows in the World sample. When we examine only those countries with initial GDP of less than $\$ 2500$ in Model 1D, we see that the significant determinants of capital inflows are not all the same as the significant determinants of capital inflows in the World sample. For the "poor" countries, initial GDP does not significantly affect capital inflows. Institutions do have a significant and positive relationship with capital inflows in the poor group. An increase of one point in institutions (not including government size and taxes) is associated with an increase in $\$ 7.21$ of annual capital inflows per capita. For the poor group, agriculture production as a percentage of GDP is negatively and significantly correlated with capital inflows. Government size and taxes does not significantly affect capital inflows in the poor group, unlike in the World sample. Distance, or remoteness, has the predicted negative sign, just as in the World sample. In a somewhat surprising result, being landlocked significantly increases capital inflows per capita in the poor group, controlling for the other explanatory variables. Of course, given such a small sample size, and controlling for income, schooling, infrastructure, and remoteness, one or two observations may significantly affect the coefficient of the landlocked dummy variable.

In Model 3D from Table III.4., I examine the determinants of capital inflows for those countries with initial GDP of greater than \$2500. In the "rich" group, initial GDP does not significantly affect capital inflows, just as in the case with the "poor" group. For the rich countries, institutions (excluding government size and taxes) are positively and 
significantly correlated with capital inflows. An increase in one point (0-10 scale) in institutional quality (or freedom) increases annual capital inflows per capita by almost $\$ 100$. For the rich countries, an increase in government size and taxes is associated with an increase in capital inflows. For example, an increase of one point in government size and taxes (which means less government or lower taxes), brings down average annual capital flows by $\$ 89.60$. Remoteness or distance does not affect capital inflows for the rich countries, controlling for other factors.

We can see significant differences and similarities comparing determinants of capital inflows in the "poor" group with the determinants of capital inflows in the "rich" group. Within each group, initial GDP does not significantly influence capital inflows, controlling for other factors. In other words, we do not see increasing returns or the Lucas Paradox within each group; we only see increasing returns when looking at the entire sample. The poor countries receive less capital inflows if they produce more agriculture ( $\%$ of GDP), while capital inflows in the rich countries are not significantly influenced by the amount of agriculture. Capital inflows in the poor countries are not significantly influenced by government size and taxes, but smaller government and lower taxes in the rich countries is negatively correlated with capital inflows. Both the rich countries and the poor countries benefit strongly from institutional quality or freedom. Remoteness is a significant factor for the poor countries, but it is not significant for the rich countries.

\section{Multicollinearity}

Institutions and initial GDP are strongly correlated. A regression shows, for instance, that the variation in initial GDP explains over half the variation in institutional 
quality (excluding government size and taxes). In the study by AKV, they find that initial GDP does not significantly affect capital inflows after controlling for institutions, and they argue that it does not because of multicollinearity. In their study, the composite institutional variable comes from the International Country Risk Guide (ICRG), which I argue is more dependent on initial GDP than a measurement of economic "freedom." In fact, we have seen that an increase in economic freedom regarding government size and taxes significantly decreases capital flows. The fact that there is multicollinearity should diminish the significance of the coefficient of initial GDP and/or institutions, but we see that in the entire sample, the coefficients for both variables remain significant.

To illustrate my point of the independent effects of initial GDP and institutions, and to compare my study to that of AKV, I graph the independent effects of initial GDP and institutions in Figures III.4a. and III.4b. In Figure III.4a., I take the residuals from the regression of capital flows on institutions against the residuals from the regression of initial GDP on institutions. The Frisch-Waugh Theorem says that the coefficient from this regression equals the coefficient for initial GDP in a regression with initial GDP and institutions as the explanatory variables, which equals 0.035 . We can easily see from Figure III.4a. that there is a positive relationship between initial GDP and capital inflows per capita, even when controlling for institutions. While the variance does increase some, the sign of the coefficient is not driven by a few observations. In Figure III.4b., in a similar procedure, I graph the effect of institutions on capital inflows per capita, controlling for initial GDP. Institutions are also positively and significantly correlated with capital inflows, with a coefficient of 51.12, when controlling for initial GDP. However, this result is very different from that of AKV. Initial GDP appears to have a 
strong independent effect, unlike the result from $\mathrm{AKV}$, and the independent effect of institutions shown in Figure III.4b seems more sensitive to outlier observations than the coefficient on initial GDP.

\section{Robustness}

The purpose of this study has been to examine increasing returns and identify the possible reasons for the lack of capital flows to poor countries. Throughout all the regressions using the entire sample, the coefficient on initial GDP has remained significant. Introducing other relevant variables that may affect capital flows, such as controlling for diseases or tropics, does not significantly change the coefficient on initial GDP. However, one may argue that GDP in 1970 picks up too many unobservable conditions that affect capital flows near that year. One way of testing the robustness of initial GDP is to only look at capital flows from 1990 to 2008. This procedure would leave a 20-year gap between the initial GDP and where capital inflows begin to be measured. In Table III.5., I run the same regressions as in Table III.4., except I use average annual capital inflows per capita from 1990 to 2008 instead of from 1970 to 2008. The results from Table III.5. are very similar to the results from Table III.4.

In Model 1E from Table III.5., we can see that the coefficient on initial GDP is positive and significant. In fact, all of the variables that were significant in Model 1D from Table III.4. are also significant in Model 1E from Table III.5. The coefficients are larger in Table III.5., which is expected given the increase in capital flows throughout the years. Models 2E and 3E from Table III.5. also yields similar results as Models 2D and 3D from Table III.4. These results suggest that there is a strong case for increasing returns throughout the entire sample, but we do not see evidence of increasing returns if 
we only focus on the poor or on the rich countries. As will be discussed later, this may suggest that there is a threshold or set of conditions that countries must possess in order to attract high levels of capital flows.

\section{III.III. Instrumental Variable Estimates}

In this section, as in the study by $\mathrm{AKV}$, I look at the possibility of a reverse causality, where capital inflows may influence institutional quality. I argue that the data from the Economic Freedom Report may be subjected to less endogeneity than the dataset used by AKV (International Country Risk Guide). The data from the Economic Freedom Report measures the amount of economic freedom in each variable, while the ICRG measures risk. While these measures may be similar, if constructing a dataset of institutions based on risk, one may naturally be inclined to assign better values to those countries that are attracting a high level of capital inflows. While it is possible that a dataset based on economic freedom may suffer from the same problem, the intuition for such a problem does not seem as strong as it does with the ICRG data.

However, to be sure that endogeneity is not a problem, I instrument institutions (not including government size or taxes) with log European settler mortality, as in Acemoglu, Johnson, and Robinson (2001). The argument for settler mortality as an instrument is that if European colonists could safely settle in a particular location, they setup better institutions with an emphasis on property rights and checks against government power, such as in Australia, New Zealand, Canada, and the U.S. If settlement was difficult or dangerous, such as in places with a high rate of disease, the colonists were more likely to set up an extractive state with less emphasis on property rights. In Acemoglu, Johnson, and Robinson (2001), they use log European settler 
mortality to see the effects of institutions on economic growth, but I will use it to see the effects of institutions on capital inflows.

First, I test to see if log European settler mortality is a valid instrument for my regressions. In order for the variable to be a valid instrument, it must be significantly correlated with institutions, but it should not independently be correlated with capital inflows. Because of the small sample size, only initial GDP, institutions (not including government size and taxes), and government size and taxes are included as explanatory variables. In Model $1 \mathrm{~F}$ from Table III.6., we see that log settler mortality is not correlated with capital inflows when controlling for initial GDP and the institutional variables in the World sample. In Model 2F, we see that log European setter mortality is correlated with institutions, when controlling for initial GDP and government size and taxes. Therefore, log settler European mortality is a valid instrument for the World sample case. When we look at the "poor" sample and the "rich" sample, we can see that $\log$ European settler mortality also meets the conditions to be a valid instrument.

In Table III.7., two-stage least squares is performed replacing institutions with its estimate derived from using log settler mortality as an instrument. In Model 1G, which is the entire available sample, we see similar results as before; initial GDP, institutions, and government size and taxes are all significant factors that influence capital inflows. The adjusted R-squared of .827 shows that the variables explain nearly all of the variation in the capital inflows. Two-stage least square do lead to different results for the poor group. In Model 2G, we see that institutions do not play a significant role in attracting capital inflows for the poor countries, but initial GDP is a significant factor. For the poor countries, the model does not explain the variation in capital inflows as well as the model 
for the rich sample or the World sample. For the rich group, institutions and government size and taxes are significant factors as they were in the OLS results. However, with the IV estimation, initial GDP is also a significant factor for the rich group. In the OLS estimation, initial GDP was near the significance threshold for the rich group, so the twostage least squares estimates are not very different than the OLS results. Overall, the IV estimates do not significantly differ from the OLS estimates. If anything, it has confirmed the results that initial GDP and institutions matter for capital inflows.

\section{III.IV. Summary and Conclusions}

The purpose of this study has been to test the prevailing theories that attempt to explain the lack of capital flows to poor countries. In particular, this study has served as a contrast to that of Alfaro, Kalemli-Ozcan, and Volosovych (2008), who concluded that different institutions solved the Lucas Paradox. Without any doubt, institutions play a key role in attracting capital flows; however, it does not eliminate the existence of increasing returns. Not only are the results by AKV sensitive to the institutional dataset, but also their choice to use the logarithm of GDP instead of the levels may have played a role in its insignificance. Nevertheless, this paper attempts to provide an explanation for increasing returns by including institutional variables and other factors that affect capital inflows.

Surprisingly, even when incorporating additional factors that may influence capital flows, such as human capital, infrastructure, and geography, the paradox of increasing returns remains. I then took a simple approach, in contrast to previous studies, and I separated the sample to see if we can explain increasing returns by comparing the "poor" countries with the "rich" countries. Graphically, from Figures III.2. and III.3., we 
have seen that there is a break point around the initial GDP level of $\$ 2500$. Conveniently, this break was around the median income level, which allowed us to divide the sample in half and have enough observations on each side to compare regressions. When comparing the "poor" countries to the "rich" countries, we have seen that the variables affect capital inflows differently in each group. For instance, agriculture production is negatively correlated with capital inflows for the poor group, but agricultural production is not a significant factor in the rich group. However, another surprise was that the coefficient on initial GDP was not significant within each group.

These results may help provide another explanation for the Lucas Paradox. Poor countries may find it difficult to compete for capital flows until they reach a certain threshold income level. Once they achieve such a threshold, or when they join the "rich" group, they will receive significantly more capital flows than what a country receives in the "poor" group. However, when a country is in the "rich" group, an increase in capital alone will not induce more capital flows. The significance of the agriculture variable in the poor group may suggest that this relates to industrialization. These results may support the poverty trap or "big push" theories (for instance, see Azariadis, Costas, and Stachurski (2004), and Murphy, et. al. (1989)). This may also give empirical support to the movement towards a bimodal world income distribution (Quah 1996), where rich, industrialized countries may attract more capital flows than poor countries.

Policymakers can certainly derive from these results the benefits of quality property rights, regulations, and legal structure. The impact of foreign aid, however, is not so clear. If the aid is big enough, so that the country becomes industrialized, the country may receive significantly more capital flows. If the aid is not large, then the 
receiving country may not receive additional capital flows. Remoteness also seems to play a key role in deterring capital flows, but how a policy can improve remoteness is beyond the scope of this paper.

Lastly, this paper may have created more questions than it answered. For instance, one surprising and robust result is that countries with a large government and high income tax rate, attract more capital flows than countries with a smaller government and lower taxes. This may be further explored in future research. The most pressing issue, however, is to empirically identify the source of increasing returns. This paper shows that increasing returns cannot easily be explained away, but it cannot specify with certainty the reason why increasing returns exists. 
Figure III.1. Capital Inflows and Initial GDP

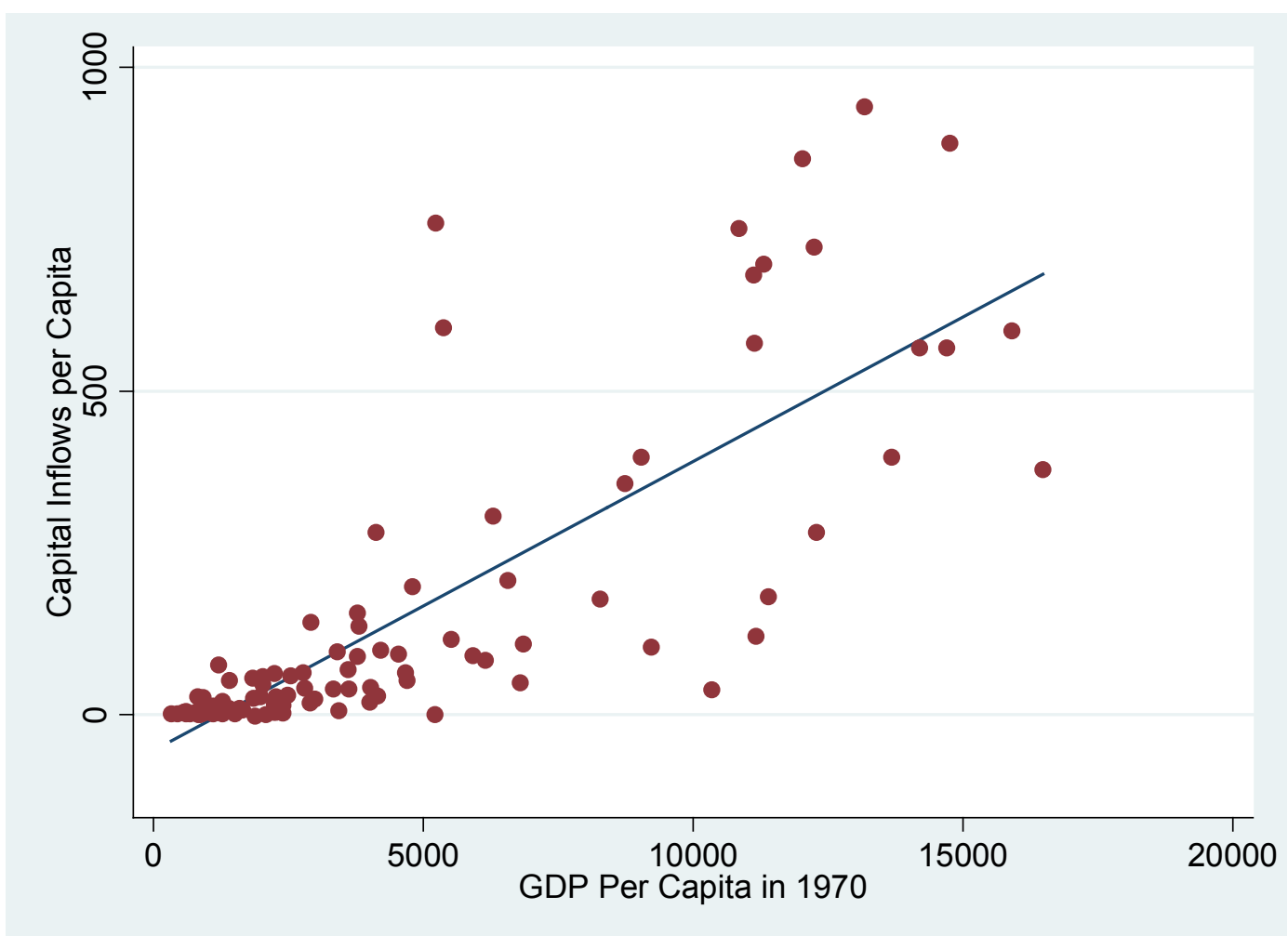

Notes: Figure III.1. graphs the regression of capital inflows on GDP per capita in 1970. Capital Inflows are measured as average annual per capita values of Foreign Direct Investment (FDI) plus Portfolio Investment from 1970 to 2008. The data is obtained from the International Monetary Fund's (IMF) International Financial Statistics (IFS). GDP in 1970 is obtained from Penn World Tables version 6.1. All values are in constant 1996 dollars. See the appendix for more details on the data. 
Figure III.2a. Capital Inflows and Initial GDP $(<2500)$

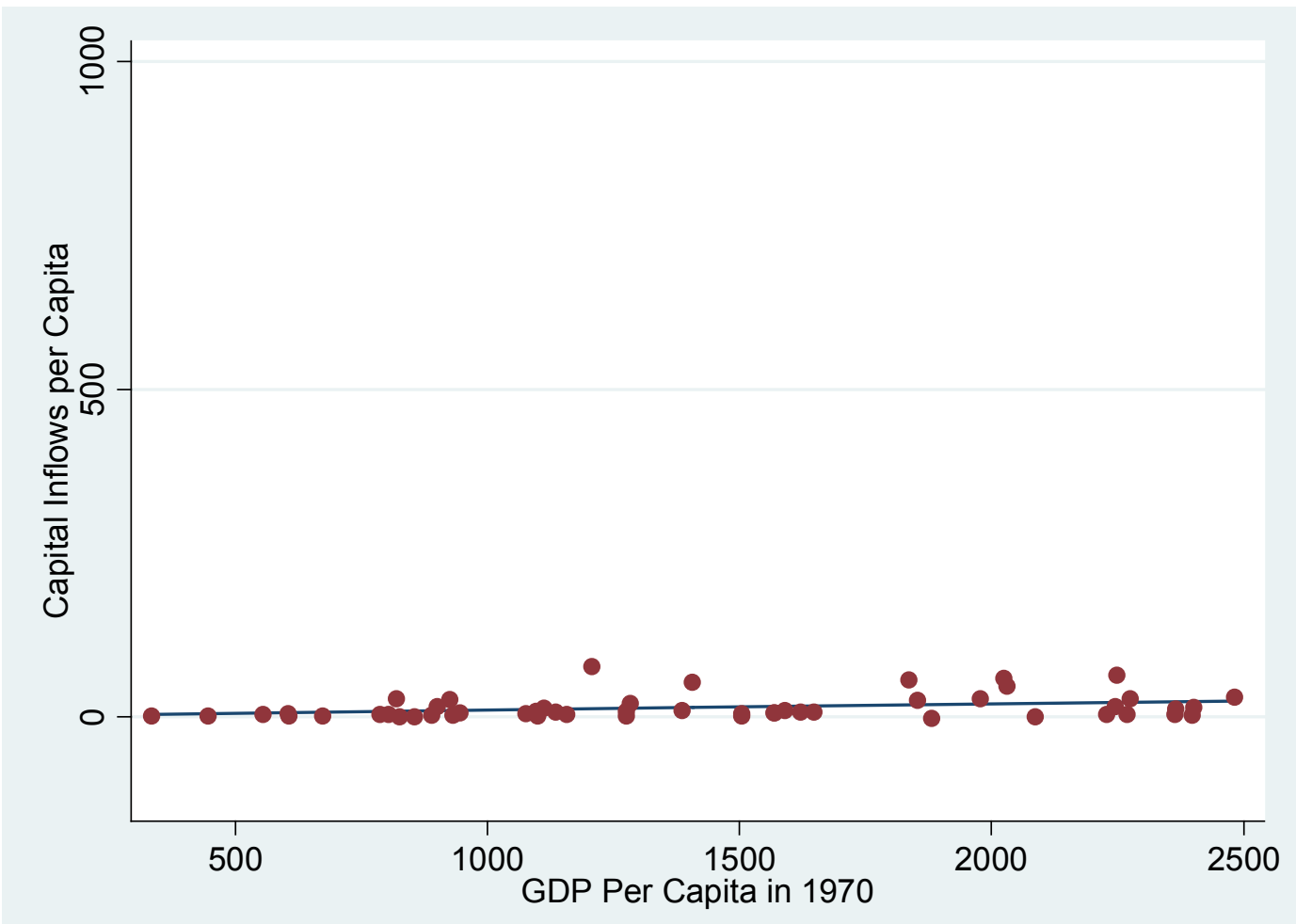

Notes: Figure III.2a. graphs the regression of capital inflows on GDP per capita in 1970 for only those countries with GDP of less than \$2500. Capital Inflows are measured as average annual per capita values of Foreign Direct Investment (FDI) plus Portfolio Investment from 1970 to 2008. The data is obtained from the International Monetary Fund's (IMF) International Financial Statistics (IFS). GDP in 1970 is obtained from Penn World Tables version 6.1. All values are in constant 1996 dollars. See the appendix for more details on the data. 
Figure III.2b. Capital Inflows and Initial GDP $(>2500)$

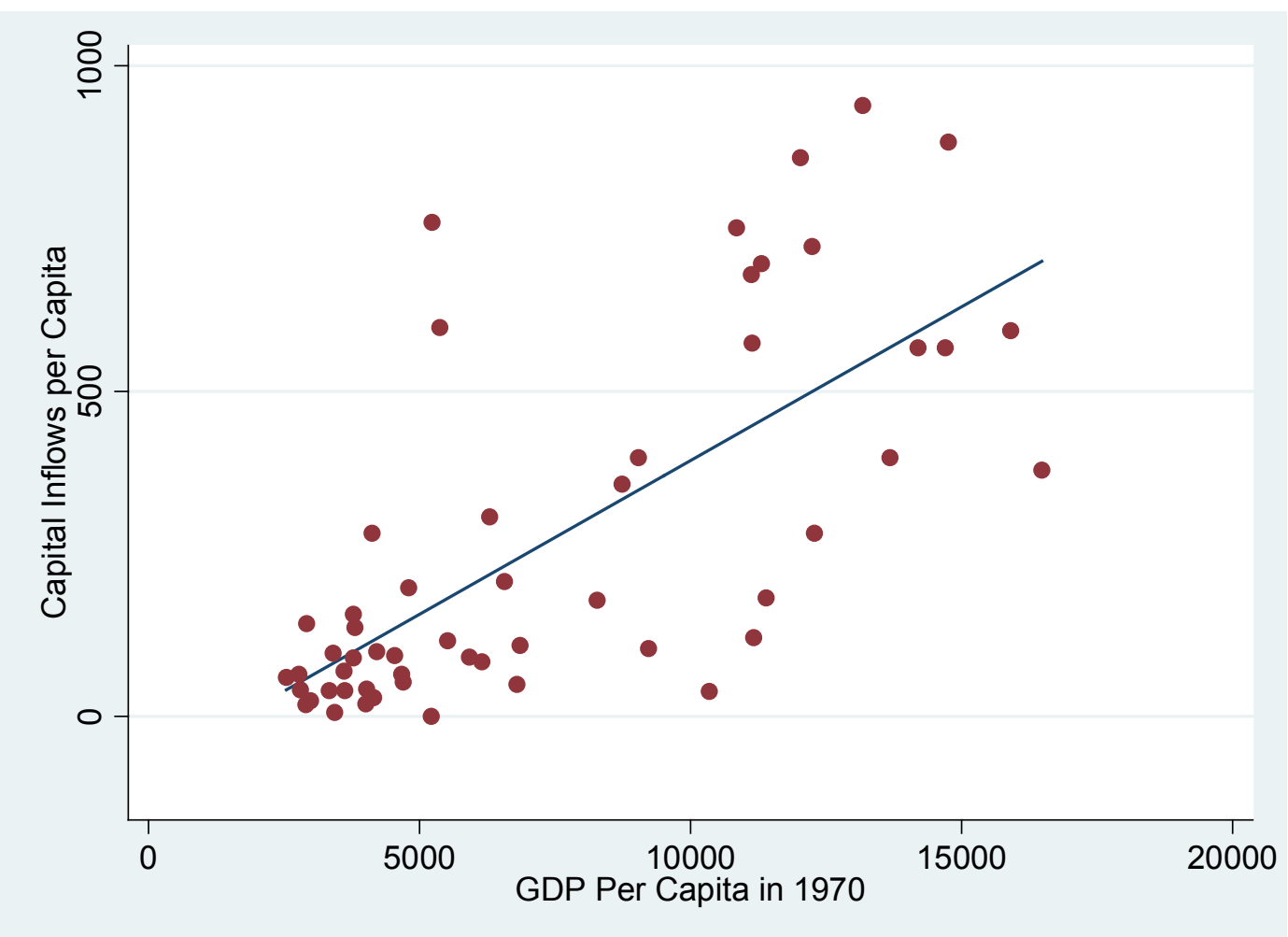

Notes: Figure III.2b. graphs the regression of capital inflows on GDP per capita in 1970, for only those countries with a GDP greater than $\$ 2500$. Capital Inflows are measured as average annual per capita values of Foreign Direct Investment (FDI) plus Portfolio Investment from 1970 to 2008 . The data is obtained from the International Monetary Fund's (IMF) International Financial Statistics (IFS). GDP in 1970 is obtained from Penn World Tables version 6.1. All values are in constant 1996 dollars. See the appendix for more details on the data. 
Figure III.3. Poor and Rich Countries

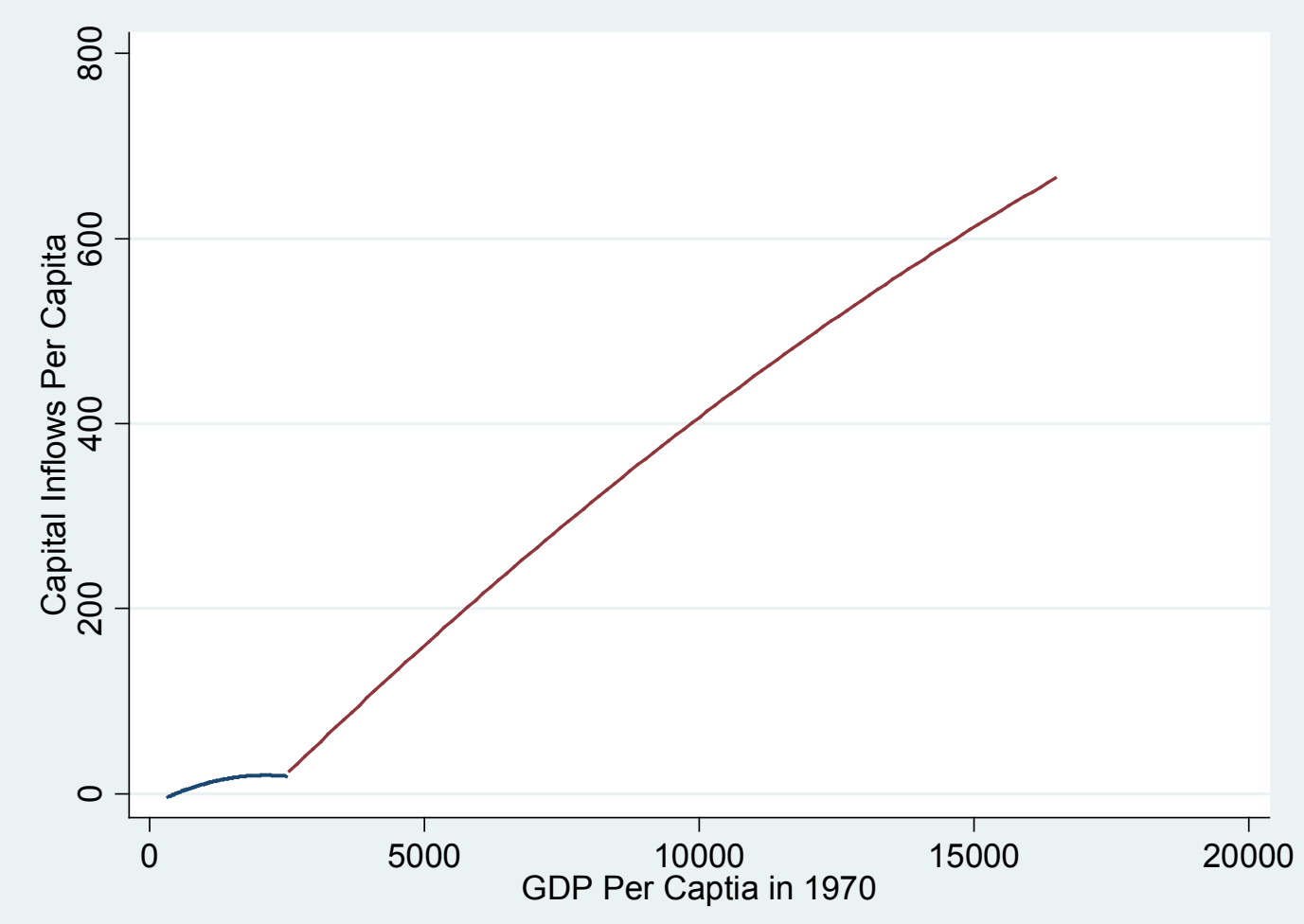

Notes: Figure III.3. graphs a quadratic regression fit of capital inflows on GDP per capita in 1970. The sample is divided where GDP equals \$2500, and a quadratic regression is fitted for both sides of the threshold. Capital Inflows are measured as average annual per capita values of Foreign Direct Investment (FDI) plus Portfolio Investment from 1970 to 2008. The data is obtained from the International Monetary Fund's (IMF) International Financial Statistics (IFS). GDP in 1970 is obtained from Penn World Tables version 6.1. All values are in constant 1996 dollars. See the appendix for more details on the data. 
Figure III.4a. Capital Inflows and Initial GDP, Controlling for Institutions

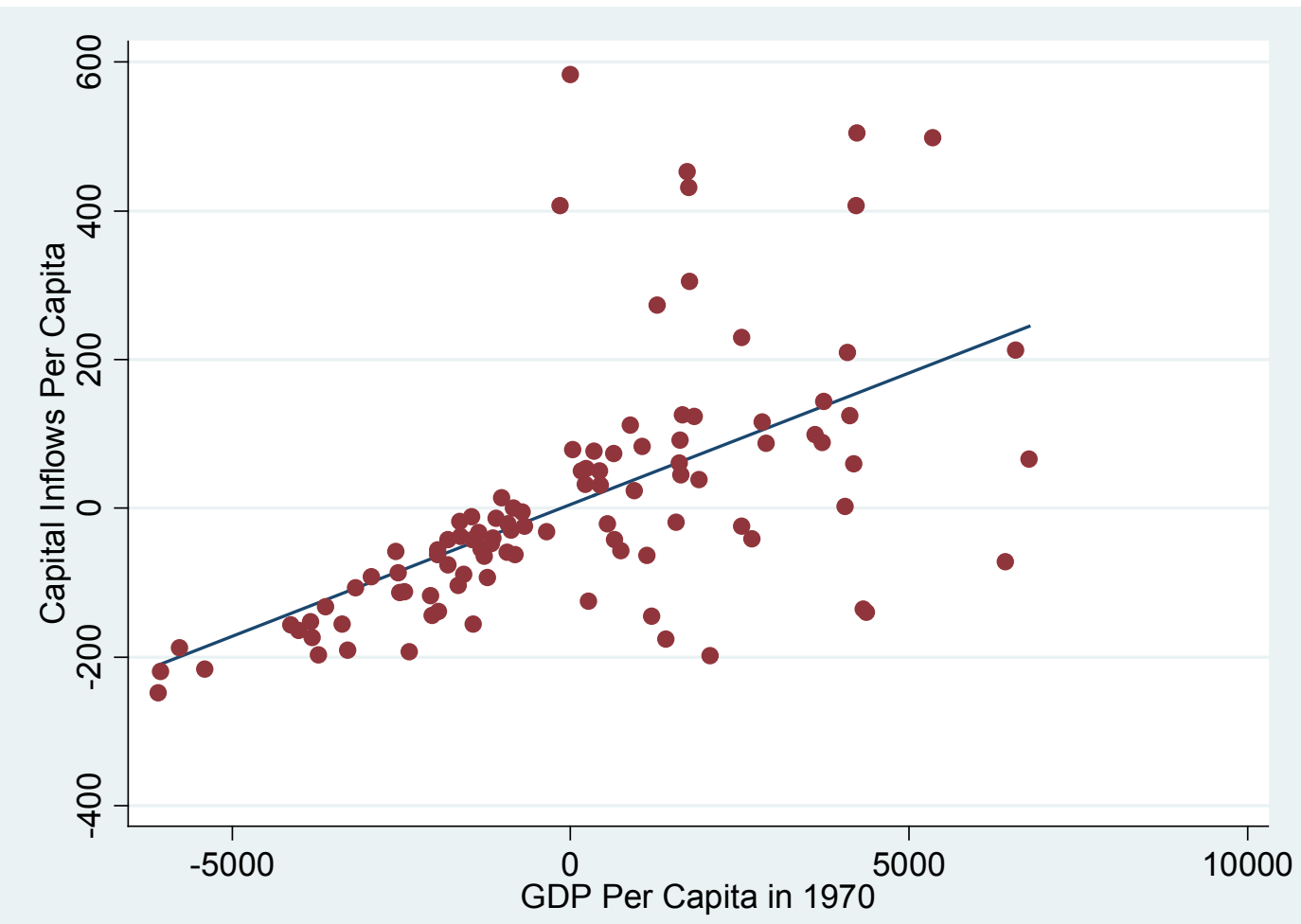

Notes: In Figure III.4a., I take the residuals from the regression of capital inflows on institutions (not including government size and taxes) against the residuals from the regression of initial GDP on institutions. The Frisch-Waugh theorem says the coefficient from this regression equals the coefficient for initial GDP in a regression with initial GDP and institutions as the explanatory variables, which equals 0.035 . The purpose of this graph is to observe the effect of initial GDP on capital inflows, controlling for institutional quality. For a description of the institutional variables, please see the appendix. 
Figure III.4b. Capital Inflows and Institutions, Controlling for Initial GDP

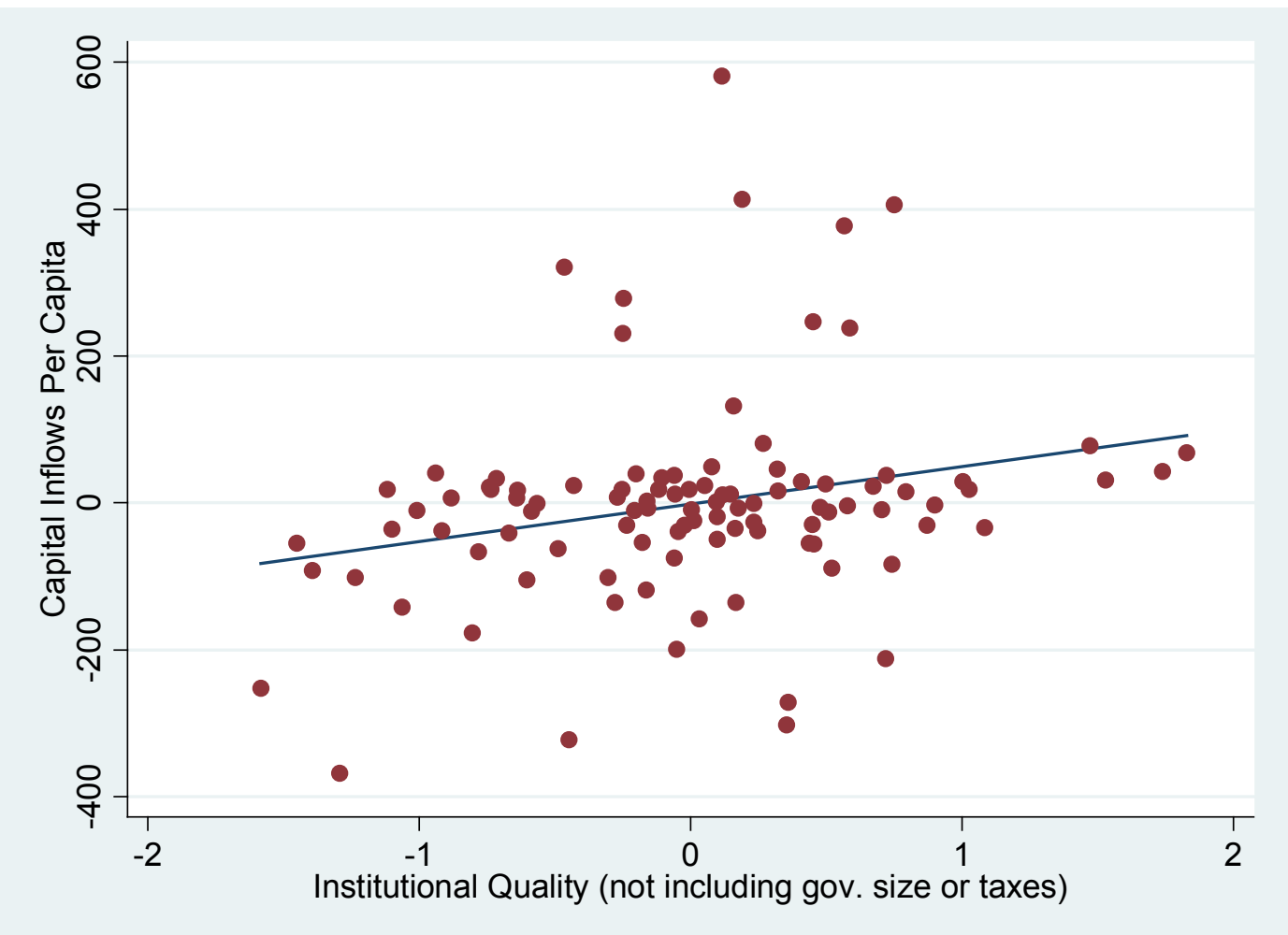

Notes: In Figure III.4b., I take the residuals from the regression of capital inflows on initial GDP against the residuals from the regression of institutions on initial GDP. The Frisch-Waugh theorem says the coefficient from this regression equals the coefficient for institutions in a regression with initial GDP and institutions as the explanatory variables, which equals 51.12. The purpose of this graph is to observe the effect of institutional quality on capital inflows, controlling for institutional quality. For a description of the institutional variables, please see the index. 
Table III.1. Capital Inflows and Initial GDP

\begin{tabular}{lccc}
\hline \hline \multicolumn{4}{c}{ Dependent Variable is Average Annual Capital Inflows Per Capita 1970-2008 } \\
\hline Variable & $\begin{array}{c}\text { Model 1A } \\
0.0447^{* * *}\end{array}$ & Model 2A & Model 3A \\
GDP Per Capita in 1970 (Entire Sample) & $(0.0032)$ & & \\
GDP Per Capita in 1970 (Poorest Half) & & $0.00936^{* *}$ & \\
& & $(0.0041)$ & \\
GDP Per Capita in 1970 (Richest Half) & & $0.0474^{* * *}$ \\
& & & $(0.0065)$ \\
Constant & $-55.4^{* * *}$ & 0.451 & -80.6 \\
& $(19.6)$ & $(6.27)$ & $(54.7)$ \\
Adjusted R-Squared & 0.643 & 0.0769 & 0.495 \\
Countries & 107 & 53 & 54
\end{tabular}

Standard errors are in parentheses. $* * * 1 \%, * * 5 \%, * 10 \%$. See the appendix for a description of the variables. 
Table III.2. Determinants of Capital Inflows (World Sample)

\begin{tabular}{lccc}
\hline \hline \multicolumn{2}{c}{ Dependent Variable is Average Annual Capital Inflows Per Capita $1970-2008$} \\
\hline Variable & Model 1B & Model 2B & Model 3B \\
GDP Per Capita in 1970 (Entire Sample) & $0.0403^{* * *}$ & & $0.0319^{* * *}$ \\
& $(0.0044)$ & & $(0.0062)$ \\
Institutions & 34.1 & $151^{* * *}$ & 36.6 \\
& $(22.6)$ & $(20.6)$ & $(25.5)$ \\
Schooling & & & 10.5 \\
& & & $(9.71)$ \\
Roads Paved (\%) & & & 0.494 \\
& & & $(0.619)$ \\
Distance & & $-0.0155^{* *}$ \\
& & $(0.0069)$ \\
Landlocked (not in Europe) & & 51.7 \\
Agriculture (\% of GDP) & & $(47.5)$ \\
Constant & $-235^{* *}$ & $-735^{* * *}$ & 1.45 \\
& $(120)$ & $(122)$ & $(1.76)$ \\
Adjusted R-Squared & & $-261^{*}$ \\
Countries & 0.647 & 0.289 & $(152)$ \\
& 101 & 131 & 0.687 \\
\end{tabular}

Standard errors are in parentheses. $* * * 1 \%, * * 5 \%, * 10 \%$. See the appendix for a description of the variables. 
Table III.3. Capital Inflows and Institutions (World Sample)

\begin{tabular}{|c|c|c|c|}
\hline \multicolumn{4}{|c|}{ Dependent Variable is Average Annual Capital Inflows Per Capita 1970-2008 } \\
\hline Variable & Model 1C & Model 2C & Model 3C \\
\hline GDP Per Capita in 1970 (Entire Sample) & $\begin{array}{c}.0248 * * * \\
(.0053)\end{array}$ & $\begin{array}{c}.0234 * * * \\
(.0053)\end{array}$ & $\begin{array}{c}.0229 * * * \\
(.0044)\end{array}$ \\
\hline Property Rights and Legal Structure & $\begin{array}{c}56.5^{* * *} \\
(16)\end{array}$ & $\begin{array}{c}36.3^{* *} \\
(15.4)\end{array}$ & $\begin{array}{c}36.6^{* * *} \\
(13.4)\end{array}$ \\
\hline Government Size and Taxes & $\begin{array}{c}-29.8^{* *} \\
(12.8)\end{array}$ & $\begin{array}{c}-38.4 * * * \\
(11.9)\end{array}$ & $\begin{array}{c}-37.5^{* * *} \\
(10.7)\end{array}$ \\
\hline Trade Freedom & $\begin{array}{l}-11.3 \\
(16.9)\end{array}$ & $\begin{array}{c}4.61 \\
(16.5)\end{array}$ & \\
\hline Sound Money & $\begin{array}{c}9.2 \\
(10.4)\end{array}$ & $\begin{array}{c}6.77 \\
(9.77)\end{array}$ & \\
\hline Business Regulations & $\begin{array}{l}15.4 \\
(19)\end{array}$ & $\begin{array}{l}31.8^{*} \\
(18.2)\end{array}$ & $\begin{array}{c}36.6^{* *} \\
(16.7)\end{array}$ \\
\hline Roads Paved (\%) & & $\begin{array}{l}-.183 \\
(.554)\end{array}$ & \\
\hline Distance & & $\begin{array}{c}-.0146 * * * \\
(.0057)\end{array}$ & $\begin{array}{c}-.0132 * * * \\
(.0048)\end{array}$ \\
\hline Landlocked (not in Europe) & & $\begin{array}{c}19.6 \\
(35.9)\end{array}$ & \\
\hline Agriculture ( $\%$ of GDP) & & $\begin{array}{c}.795 \\
(1.36)\end{array}$ & \\
\hline Constant & $\begin{array}{l}-170 \\
(118)\end{array}$ & $\begin{array}{l}-136 \\
(128)\end{array}$ & $\begin{array}{l}-91.7 \\
(92.7)\end{array}$ \\
\hline Adjusted R-Squared & .707 & .756 & .775 \\
\hline Countries & 101 & 94 & 96 \\
\hline
\end{tabular}

Standard errors are in parentheses. $* * * 1 \%, * * 5 \%, * 10 \%$. See the appendix for a description of the variables. 
Table III.4. Poor and Rich Countries

\begin{tabular}{|c|c|c|c|}
\hline \multicolumn{4}{|c|}{ Dependent Variable is Average Annual Capital Inflows Per Capita 1970-2008 } \\
\hline Variable & Model 1D & Model 2D & Model 3D \\
\hline GDP Per Capita in 1970 (Entire Sample) & $\begin{array}{c}0.0241^{* * *} \\
(0.0058)\end{array}$ & & \\
\hline GDP Per Capital in 1970 (Poorest Half) & & $\begin{array}{c}0.0003 \\
(0.0045)\end{array}$ & \\
\hline GDP Per Capital in 1970 (Richest Half) & & & $\begin{array}{c}0.0156 \\
(0.0109)\end{array}$ \\
\hline Institutions (not incl. Gov. size/taxes) & $\begin{array}{c}66^{* * * *} \\
(20)\end{array}$ & $\begin{array}{l}7.21^{* *} \\
(3.55)\end{array}$ & $\begin{array}{c}99.4 * * * \\
(39.1)\end{array}$ \\
\hline Schooling & $\begin{array}{c}6.08 \\
(8.68)\end{array}$ & $\begin{array}{c}1.33 \\
(1.36)\end{array}$ & $\begin{array}{l}0.698 \\
(18.8)\end{array}$ \\
\hline Agriculture (\% of GDP) & $\begin{array}{c}0.95 \\
(1.58)\end{array}$ & $\begin{array}{c}-0.784 * * * \\
(0.235)\end{array}$ & $\begin{array}{l}-0.947 \\
(5.68)\end{array}$ \\
\hline Roads Paved (\%) & $\begin{array}{l}-0.354 \\
(0.58)\end{array}$ & $\begin{array}{c}0.147 \\
(0.105)\end{array}$ & $\begin{array}{l}-0.74 \\
(1.05)\end{array}$ \\
\hline Government Size and Taxes & $\begin{array}{c}-50.4 * * * \\
(12.6)\end{array}$ & $\begin{array}{l}-2.87 \\
(2.24)\end{array}$ & $\begin{array}{c}-89.6^{* * * *} \\
(26.2)\end{array}$ \\
\hline Landlocked (not in Europe) & $\begin{array}{c}18.6 \\
(42.8)\end{array}$ & $\begin{array}{c}14.4 * * * \\
(5.29)\end{array}$ & $\begin{array}{c}171 \\
(189)\end{array}$ \\
\hline Distance & $\begin{array}{l}-0.0111^{*} \\
(0.0062)\end{array}$ & $\begin{array}{c}-0.00258 * \\
(0.0014)\end{array}$ & $\begin{array}{r}-0.00582 \\
(0.0105)\end{array}$ \\
\hline Constant & $\begin{array}{l}-51.5 \\
(137)\end{array}$ & $\begin{array}{c}17 \\
(27)\end{array}$ & $\begin{array}{c}73.4 \\
(249)\end{array}$ \\
\hline Adjusted R-Squared & 0.752 & 0.601 & 0.682 \\
\hline Countries & 84 & 41 & 43 \\
\hline
\end{tabular}

Standard errors are in parentheses. $* * * 1 \%, * * 5 \%, * 10 \%$. See the appendix for a description of the variables. 
Table III.5. Robustness of Initial GDP

\begin{tabular}{|c|c|c|c|}
\hline \multicolumn{4}{|c|}{ Dependent Variable is Average Annual Capital Inflows Per Capita 1990-2008 } \\
\hline Variable & Model 1E & Model 2E & Model 3E \\
\hline GDP Per Capita in 1970 (Entire Sample) & $\begin{array}{c}0.041 * * * \\
(0.0104)\end{array}$ & & \\
\hline GDP Per Capita in 1970(Poorest Half) & & $\begin{array}{l}0.00048 \\
(0.0075)\end{array}$ & \\
\hline GDP Per Capita in 1970 (Richest Half) & & & $\begin{array}{c}0.0315 \\
(0.0189)\end{array}$ \\
\hline Institutions (not incl. Gov. size/taxes) & $\begin{array}{c}116^{* * *} \\
(36.4)\end{array}$ & $\begin{array}{c}6.8 \\
(6.16)\end{array}$ & $\begin{array}{c}171 * * * \\
(67.9)\end{array}$ \\
\hline Schooling & $\begin{array}{c}5.68 \\
(15.4)\end{array}$ & $\begin{array}{l}3.81 * \\
(2.26)\end{array}$ & $\begin{array}{l}-9.19 \\
(32.7)\end{array}$ \\
\hline Agriculture (\% of GDP) & $\begin{array}{c}1.12 \\
(2.97)\end{array}$ & $\begin{array}{c}-0.883^{* *} \\
(0.41)\end{array}$ & $\begin{array}{c}-2.4 \\
(9.88)\end{array}$ \\
\hline Roads Paved (\%) & $\begin{array}{l}-0.666 \\
(1.02)\end{array}$ & $\begin{array}{c}0.353 * * \\
(0.175)\end{array}$ & $\begin{array}{l}-1.36 \\
(1.82)\end{array}$ \\
\hline Government Size and Taxes & $\begin{array}{c}-92.6^{* * *} \\
(22.9)\end{array}$ & $\begin{array}{c}1.31 \\
(3.87)\end{array}$ & $\begin{array}{c}-161 * * * \\
(45.6)\end{array}$ \\
\hline Landlocked (not in Europe) & $\begin{array}{c}49.5 \\
(78.6)\end{array}$ & $\begin{array}{c}20.2 * * \\
(9.05)\end{array}$ & $\begin{array}{c}348 \\
(328)\end{array}$ \\
\hline Distance & $\begin{array}{c}-0.0181 * \\
(0.011)\end{array}$ & $\begin{array}{c}-0.00452 * \\
(0.0023)\end{array}$ & $\begin{array}{r}-0.00889 \\
(0.0182)\end{array}$ \\
\hline Constant & $\begin{array}{l}-53.9 \\
(242)\end{array}$ & $\begin{array}{l}-1.18 \\
(44.8)\end{array}$ & $\begin{array}{c}177 \\
(433)\end{array}$ \\
\hline Adjusted R-Squared & 0.74 & 0.545 & 0.68 \\
\hline Countries & 83 & 40 & 43 \\
\hline
\end{tabular}

Standard errors are in parentheses. $* * * 1 \%, * * 5 \%, * 10 \%$. See the appendix for a description of the variables. 
Table III.6. Testing for Validity of the Instrumental Variable

For Models 1F, 3F, and 5F the dependent variable is average annual capital inflows. For Models 2F, 4F, and $6 \mathrm{~F}$, the dependent variable is Institutions (excluding government size/taxes)

\begin{tabular}{|c|c|c|c|c|c|c|}
\hline $\begin{array}{r}\text { Dependent } \\
\text { Variable: }\end{array}$ & $\begin{array}{l}\text { Capital } \\
\text { Inflows }\end{array}$ & Institutions & $\begin{array}{l}\text { Capital } \\
\text { Inflows }\end{array}$ & Institutions & $\begin{array}{l}\text { Capital } \\
\text { Inflows }\end{array}$ & Institutions \\
\hline Variable & Model 1F & Model 2F & Model 3F & Model 4F & Model 5F & Model 6F \\
\hline \\
\hline Sample) & $\begin{array}{c}.0216^{* * *} \\
(.0026)\end{array}$ & $\begin{array}{l}.00013 * * * \\
(.00003)\end{array}$ & & & & \\
\hline \multicolumn{7}{|l|}{$\begin{array}{l}\text { GDP Per Capita } \\
\text { in } 1970 \text { (Poorest }\end{array}$} \\
\hline Half) & & & $\begin{array}{c}.00914 * * * \\
(.0029)\end{array}$ & $\begin{array}{l}0.00031^{*} \\
(0.00017)\end{array}$ & & \\
\hline \multicolumn{7}{|l|}{$\begin{array}{l}\text { GDP Per Capita } \\
\text { in } 1970 \text { (Richest }\end{array}$} \\
\hline Half) & & & & & $\begin{array}{c}0.0192 * * * \\
(0.0043)\end{array}$ & $\begin{array}{l}0.00011^{* *} \\
(0.000049)\end{array}$ \\
\hline \multicolumn{7}{|l|}{$\begin{array}{l}\text { Institutions (not } \\
\text { incl. Gov. }\end{array}$} \\
\hline & $(10.2)$ & & $(3.31)$ & & $(16.4)$ & \\
\hline $\begin{array}{l}\text { Government Size } \\
\text { and Taxes }\end{array}$ & $-15.4 * *$ & $.17 * *$ & 2.77 & 0.163 & $-25.1 * *$ & 0.154 \\
\hline & $(6.35)$ & $(.0822)$ & $(1.86)$ & $(0.113)$ & $(10.5)$ & $(0.127)$ \\
\hline \multicolumn{7}{|l|}{ Log Settler } \\
\hline Mortality & $\begin{array}{c}3.23 \\
(7.27)\end{array}$ & $\begin{array}{c}-.271^{* * * *} \\
(.0907)\end{array}$ & $\begin{array}{l}-.761 \\
(1.59)\end{array}$ & $\begin{array}{l}-0.178^{*} \\
(0.0937)\end{array}$ & $\begin{array}{c}-8.7 \\
(17.6)\end{array}$ & $\begin{array}{l}-0.46^{* *} \\
(0.199)\end{array}$ \\
\hline Constant & $\begin{array}{l}-188^{* *} \\
(76.1)\end{array}$ & $\begin{array}{c}5.23 * * * \\
(.726)\end{array}$ & $\begin{array}{l}-25.9 \\
(20.8)\end{array}$ & $\begin{array}{l}4.56^{* * *} \\
(0.874)\end{array}$ & $\begin{array}{l}-167 \\
(150)\end{array}$ & $\begin{array}{c}6.22 * * * \\
(1.38)\end{array}$ \\
\hline $\begin{array}{l}\text { Adjusted R- } \\
\text { Squared }\end{array}$ & .824 & .534 & .305 & 0.19 & 0.814 & 0.469 \\
\hline Countries & 61 & 62 & 33 & 34 & 28 & 28 \\
\hline
\end{tabular}


Table III.7. Two-Stage Least Squares

\begin{tabular}{|c|c|c|c|}
\hline \multicolumn{4}{|c|}{$\begin{array}{c}\text { Dependent Variable is Average Annual Capital Inflows Per Capita 1970-2008. Institutions (not incl. } \\
\text { Gov. size/taxes) is instrumented with Log Settler Mortality }\end{array}$} \\
\hline Variable & Model $1 \mathrm{G}$ & Model 2G & Model 3G \\
\hline GDP Per Capita in 1970 (Entire Sample) & $\begin{array}{c}0.0213 * * * \\
(0.0025)\end{array}$ & & \\
\hline GDP Per Capita in 1970 (Poorest Half) & & $\begin{array}{c}0.00926^{* * *} \\
(0.0028)\end{array}$ & \\
\hline GDP Per Capita in 1970 (Richest Half) & & & $\begin{array}{c}0.0199 * * * \\
(0.004)\end{array}$ \\
\hline Institutions (not incl. Gov. size/taxes) & $\begin{array}{c}44.9 * * * \\
(9.41)\end{array}$ & $\begin{array}{c}2.38277 \\
(3.04)\end{array}$ & $\begin{array}{c}66.04 * * * \\
(14.58)\end{array}$ \\
\hline Government Size and Taxes & $\begin{array}{c}-15.3 * * \\
(6.3)\end{array}$ & $\begin{array}{c}2.64 \\
(1.81)\end{array}$ & $\begin{array}{l}-25^{* *} \\
(10.3)\end{array}$ \\
\hline Constant & $\begin{array}{c}-164 * * * \\
(51.5)\end{array}$ & $\begin{array}{c}-32.2 * * \\
(15.9)\end{array}$ & $\begin{array}{c}-228 * * * \\
(84.7)\end{array}$ \\
\hline Adjusted R-Squared & 0.827 & 0.323 & 0.82 \\
\hline Countries & 61 & 33 & 28 \\
\hline
\end{tabular}

Standard errors are in parentheses. $* * * 1 \%, * * 5 \%, * 10 \%$. See the appendix for a description of the variables. 


\section{LIST OF REFERENCES}

Acemoglu, D., Johnson, S., \& Robinson, J. A. (2001). The colonial origins of comparative development: an empirical investigation. American Economic Review, 91, 1369-1401.

Alfaro, L., Kalemli-Ozcan, S., \& Volosovych, V. (2008, May). Why doesn't capital flow from rich to poor countries? An empirical investigation. Review of Economics \& Statistics, 90(2), 347-368.

Atkeson, A. (1991, July). International lending with moral hazard and risk of repudiation. Econometrica, 59(4), 1069-1089.

Azariadis, C., \& Stachurski, J. (2004). Poverty traps. In P. Aghion \& S. Durlauf (Eds.) Handbook of Economic Growth. Amsterdam: North Holland.

Barro, R.J. \& Lee, J.W. (2000). International data on educational attainment: updates and implications. The Center for International Development at Harvard University Working Paper 42.

Bulow, J. \& Rogoff, K. (1989). A constant re-contracting model of sovereign debt. Journal of Political Economy, 97(1), 155-178.

Corsetti, G., Guimaraes, B., \& Roubini, N. (2006). International lending of last resort and moral hazard: a model of IMF's catalytic finance. Journal of Monetary Economics, 53, 441-471.

Duggal, V. G., Saltzman C., \& Klein, L. (2007, October). Infrastructure and productivity: an extension to private infrastructure and IT productivity. Journal of Econometrics, 140(2),485-502.

Duggal, V.G., Saltzman, C., \& Klein, L. (1999, September). Infrastructure and productivity: a nonlinear approach. Journal of Econometrics, 92(1), 47-74.

Easterly, W. (2006). Reliving the 1950s: the big push, poverty traps, and takeoffs in economic development. Journal of Economic Growth, 11, 289-318.

Eaton, J., \& Gersovitz, M. (1981). Debt with potential repudiation: theoretical and empirical analysis. Review of Economic Studies, 48(2), 289-309.

Fingleton, B., \& McCombie, J. (1998). Increasing returns and economic growth: some evidence for manufacturing from the European Union regions. Oxford Economic Papers, 50, 89-105. 
Gallup, J.L., Sachs, J.D., \& Mellinger, A. (1999, March), Geography and economic development. CID Working Paper No. 1.

Gertler, M., \& Rogoff, K. (1990, October). North-South lending and endogenous capitalmarket inefficiencies. Journal of Monetary Economics, 26, 245-266.

Gwartney, J., \& Lawson, R. (2009). Economic Freedom of the World: 2009 Annual Report. The Fraser Institute.

Gylfason, T. (2001, May). Natural resources, education, and economic development. European Economic Review, 45(4-6), 847-859.

Heston, A., Summers, R., \& Aten, B. (2002). Penn World Table Version 6.1. Center for International Comparisons at the University of Pennsylvania (CICUP).

International Monetary Fund, International Financial Statistics (2009). The International Monetary Fund, Washington, D.C.

Jones, C. (1997, Summer). On the evolution of the world income distribution. Journal of Economics Perspectives 11(3), 19-36.

Judd, K.L. (1997, February). Computational economics and economic theory: substitutes or complements? NBER Working Paper No. T0208.

Karayalcin, C., McCollister, K. \& Mitra, D. (2002). Infrastructure, returns to scale and sovereign debt. The Journal of International Trade \& Economic Development, 11(3), 267-278.

Krugman, P. (1987, October). The narrow moving band, the Dutch Disease, and the competitive consequences of Mrs. Thatcher. Journal of Development Economics, 27(1-2), 41-55.

Lane, P.R. (1999). North-South lending with moral hazard and repudiation risk. Review of International Economics, 7(1), 50-59.

Lucas, R.E. (1990). Why doesn't capital flow rich to poor countries? American Economic Review, 80(2), 92-96.

Matsuyama, K. (1992, December). Agricultural productivity, comparative advantage, and economic growth. The Journal of Economic Theory, 58(2), 317-334.

Murphy, K.M., Shleifer, A., \& Vishney, R.W. (1989, October). Industrialization and the Big Push. The Journal of Political Economy, 97(5), 1003-1026. 
North, D.C. (1994, June). Economic performance through time. The American Economic Review 84(3), 359-368.

Obstfeld, M., \& Rogoff, K. (1996). Foundations of International Macroeconomics. Cambridge, Mass: MIT Press

Obstfeld, M., \& Rogoff K. (2000). The six major puzzles in international macroeconomics: Is there a common cause? In NBER Macroeconomics, 15, 339390. The University of Chicago Press.

Oliveira, F.H.P., Jayme, F.G., Jr., \& Lemos, M.B. (2006). Increasing returns to scale and international diffusion of technology: an empirical study for Brazil (1976-2000). World Developmen, 34(1), 75-88.

Park, S.R., \& Kwon, J. (1995, May). Rapid economic growth with increasing returns to scale and little or no productivity growth. Review of Economics and Statistics, 77(2), 332-351.

Quah, D. (1996, July). Twin peaks: growth and convergence in models of distribution dynamics. Economic Journal, 106(437), 1045-1055.

Reinhart, C.M., \& Rogoff, K. (2004, May). Serial default and the 'Paradox' of rich-topoor capital flows. The American Economic Review, 94(2), 53-58.

Rodriguez, F. (2008, August). An empirical test of the poverty traps hypothesis. International Poverty Centre. United Nations Development Programme. Technical Paper No. 4.

Romer, P.M. (1986, October). Increasing returns and long-run growth. The Journal of Political Economy, 94(5), 1002-1037.

Rosentsein-Rodan, P.N. (1943, June-September). Problems of industrialization of Eastern and South-Eastern Europe. The Economic Journal, 53(210/211), 202211.

Sachs, J.D., \& Warner, A.M. (1995, December). Natural Resource Abundance and Economic Growth. Working Paper 5398, National Bureau of Economic Research.

Solow, R.M. (1956, February). A contribution to the theory of economic growth. Quarterly Journal of Economics, 70(1), 65-94.

Spiegel, M.M. (1995). Threshold effects in international lending. Journal of Development Economics, 46, 341-356. 
Tomz, M. (2007). Reputation and International Cooperation: Sovereign Debt Across Three Centuries. Princeton University Press.

World Bank, World Development Indicators (2009). The World Bank, Washington, D.C.

World Development Report (2008). Agriculture for Development. The World Bank, Washington, D.C. www.worldbank.org. 


\section{APPENDICES}

\section{Appendix for Chapter I.}

Proposition: With diminishing returns to investment, in response to capital account liberalization, savings will flow from the Rich to the Poor country; reverse flows cannot take place.

Proof: To prove this, I need to show that richer economies have lower interest rates in autarky under diminishing returns than poor economies. In autarky, investment per entrepreneur is equal to the total income of the country per entrepreneur, $I=\frac{y_{1}}{1-s}$. The equilibrium interest rate in autarky is the rate which satisfies both the incentive constraint of the borrowers and the zero-profit condition of the lenders, where $P(Z)=Z-\frac{R}{\pi^{\prime}(I)}=\frac{R\left(I-Y_{1}\right)}{\pi(I)}$. Solving for $R$ and substituting for investment, we have $R=Z\left(\frac{s y_{1}}{(1-s) \pi\left(\frac{y_{1}}{(1-s)}\right)}+\frac{1}{\pi^{\prime}\left(\frac{y_{1}}{(1-s)}\right)}\right)^{-1}$, which is the same as equation (11). Taking the derivative with respect to the endowment income we have

$$
\frac{\partial R}{\partial y_{1}}=-Z\left(\frac{\frac{s(1-s) \pi(I)-s y_{1} \pi^{\prime}(I)}{[(1-s) \pi(I)]^{2}}-\frac{\pi^{\prime \prime}(I)}{(1-s) \pi^{\prime}(I)^{2}}}{\left(\frac{s I}{\pi(I)}+\frac{1}{\pi^{\prime}(I)}\right)^{2}}\right)
$$

which is negative if $s(1-s) \pi(I)-s y_{1} \pi^{\prime}(I)>0$. Dividing by $s(1-s)$, the inequality can be written as $\pi(I)>\pi^{\prime}(I) I$, which is will always be true under diminishing returns. This completes the proof. 
Under increasing returns, one can easily use the same proof to show that it is possible to have $\frac{\partial R}{\partial y_{1}}>0$. Since the autarkic interest rate in the Rich country may be higher than that of the Poor country, capital, therefore, can flow from the Poor to the Rich as we go from autarky to free international capital flows.

\section{Appendix for Chapter II.}

To illustrate the results from the figures, the following production functions were used:

$F\left(K_{2}^{N}\right)=6\left(K_{2}^{N}\right)^{1 / 3}$,

and

$F\left(K_{2}^{M}\right)=\frac{25\left(K_{2}^{M}\right)^{13 / 6}}{\left(K_{2}^{M}\right)^{2}+500}$.

Other similar functions can be used as well. I used an interest rate of 0.10 . To illustrate the results under collateral differences across sectors, I set $z=0.07$ and $n=0.27$ (for the initial results, I set both parameters equal).

The variable of interest is the initial income, $Y_{1}$, and how it affects the equilibrium debt and output. The value of default is given in equation (7) and the value of repayment is given in equation (8). To solve for the equilibrium debt level, and to construct Figure II.9., I set the value of default equal to the value of repayment at different initial income levels. To construct Figures II.10. and II.11., initial income and debt is given, so insert $\left(Y_{1}+D_{2}-K_{2}^{M}\right)$ in the place of $K_{2}^{N}$ in the value functions. 


\section{Appendix for Chapter III.}

\section{Data Description and Sources}

Capital Inflows: Average annual per capita values of Foreign Direct Investment (FDI) and Portfolio Investment from 1970 to 2008 . The data is obtained from the International Monetary Fund's (IMF) International Financial Statistics (IFS). As a measure of FDI, I use Foreign direct investment in reporting economy, n.i.e. (IFS line 78bed). Direct investment includes equity capital, reinvested earnings, other capital, and financial derivatives associated with various intercompany transactions between affiliated enterprises measured in current U.S. dollars. As a measure of portfolio investment, I use Equity securities liabilities (IFS line 78bmd), which includes flows of shares, stock participations, and similar documents that denote ownership of equity measured in current U.S. dollars. (The IMF classifies direct investment as involving ownership of at least 10 percent of the local firm's equity. Other equity purchases are included in this category.) I express the inflows in constant 1996 U.S. dollars, and to convert to per capita measures I divide by the population in each year.

Population: 1970-2008. Total population from World Bank, World Development Indicators, 2009.

Consumer Price Index (CPI): U.S. CPI with base year $1996=1$. CPI with a base year of 2005 was obtained from World Bank, World Development Indicators, but it was adjusted to 1996.

Real GDP Per Capita: Gross Domestic Product (GDP) per capita in 1970 in constant 1996 dollars obtained from Penn World Tables version 6.1. 
Institutional variables: For the institutional variables, I take advantage of the dataset compiled in the Economic Freedom of the World 2009 Annual Report (which can be found at www.freetheworld.com). Each variable is given a value from 0 to 10 . Generally speaking, a higher number represents more freedom or less restriction. I take the average of each variable from 1970 to 2005 , where equal weight is put on each five-year interval. The following provides the components of each institutional variable, but for a detailed description of each variable, please see the appendix of the Economic Freedom report.

- Institutions: A composite variable, which is the average of all the other institutional variables.

- Institutions (not including government size and taxes): A composite variable, which is the average of all the other institutional variables, except_Size of Government: Expenditures, Taxes, and Enterprises.

- Size of Government: Expenditures, Taxes, and Enterprises (I labeled as Government Size and Taxes): A composite variable, which is the average of the following variables:

- General government consumption spending as a percentage of total consumption

- Transfers and subsidies as a percentage of GDP

- Government enterprises and investment

- Top marginal tax rate

- Top marginal income tax rate

- Top marginal income and payroll tax rates 
- Legal Structure and Security of Property Rights (I labeled as Property Rights and Legal Structure): A composite variable, which is the average of the following variables

○ Judicial independence

- Impartial courts

- Protection of property rights

- Military interference in rule of law and the political process

- Integrity of the legal system

- Legal enforcement of contracts

- Regulatory restrictions on the sale of real property

- Access to Sound Money (I labeled as Sound Money): A composite variable that is the average of the following variables:

- Moneygrowth

- Standard deviation of inflation

- Inflation: Most recent year

- Freedom to own foreign currency bank accounts

- Freedom to Trade Internationally (I labeled as Trade Freedom): A composite variable that is the average of the following variables:

- Taxes on international trade

- Revenues from trade taxes (\% of trade sector)

- Mean tariff rate

- Standard deviation of tariff rates

- Regulatory Trade Barriers 
- Non-tariff trade barriers

- Compliance cost of importing and exporting

- Size of the trade sector relative to expected

- Black-market exchange rates

- International capital market controls

- Foreign ownership/investment restrictions

- Capital controls

- Regulation of Credit, Labor, and Business (I labeled as Business Regulation): A composite variable that is the average of the following variables:

- Credit market regulations

- Ownership of banks

- Foreign bank competition

- Private sector credit

- Interest rate controls / negative real interest rates

- Labor market regulations

- Minimum wage

- Hiring and firing regulations

- Centralized collective bargaining

- Mandated cost of hiring

- Mandated cost of worker dismissal

- Conscription

- Business Regulations

- Price controls 
- Administrative requirements

- Bureaucracycosts

- Starting a business

- Extra payments / bribes

- Licensing restrictions

- Cost of tax compliance

Schooling: Average years of total schooling for age 25 and older from years 1970, 1975, 1980, 1985, 1990, 1995, and 2000. Data from Barro, Robert J. and Jong-Wha Lee (2000), "International Data on Educational Attainment: Updates and Implications," Center for International Development at Harvard University (CID) Working Paper No. 42, April 2000.

Roads Paved (\%): Percentage of total roads that are paved, average from 1990-2008. Data from World Bank, World Development Indicators.

Agriculture: Agriculture value added, percentage of GDP. Average from 1970-2008. World Bank, World Development Indicators.

Landlocked, not in Europe: Indicator for landlocked country, excluding countries in Western and Central Europe (Austria, the Czech Republic, Hungary, the Former Yugoslav Republic of Macedonia, Slovakia, and Switzerland). Includes Eastern European countries of Belarus and Moldova. Data obtained from Gallup, John L. and Jeffrey D. Sachs, with Andrew Mellinger, "Geography and Economic Development" (CID Working Paper No. 1, March 1999).

Distance: Air distance in kilometers to one of the three capital-goods-supplying regions: the U.S., Western Europe, and Japan, specifically measured as distance from the 
country's capital city to New York, Rotterdam, or Tokyo. Data obtained from Gallup, John L. and Jeffrey D. Sachs, with Andrew Mellinger, "Geography and Economic Development" (CID Working Paper No. 1, March 1999).

Log European Settler Mortality: The logarithm of the historical European settler's mortality rates from Acemoglu, Johnson, and Robinson (2001). Mortality rates are deaths per annum per 1000 .

Table III.8. Data Samples.

List of countries from selected tables. The list shows the fullest sample in each table. Some countries fall out of other regressions because of data availability.

\begin{tabular}{|c|c|c|c|c|c|}
\hline \multicolumn{2}{|c|}{$\begin{array}{c}\text { Table III.1 } \\
\text { (107 Countries) }\end{array}$} & \multicolumn{3}{|c|}{$\begin{array}{c}\text { Table III.2. } \\
\text { (131) }\end{array}$} & $\begin{array}{c}\text { Table III.6. } \\
(61)\end{array}$ \\
\hline Algeria & Malaysia & Albania & Jamaica & Uganda & Algeria \\
\hline Angola & Mali & Algeria & Japan & $\begin{array}{l}\text { Ukraine } \\
\text { United }\end{array}$ & Angola \\
\hline Argentina & Mauritania & Angola & Jordan & Kingdom & Argentina \\
\hline Australia & Mauritius & Argentina & Kazakhstan & United States & Australia \\
\hline Austria & Mexico & Armenia & Kenya & Uruguay & Bangladesh \\
\hline Bangladesh & Morocco & Australia & Korea, Rep. & Venezuela & Barbados \\
\hline Barbados & Mozambique & Austria & $\begin{array}{l}\text { Kuwait } \\
\text { Kyrgyz }\end{array}$ & Vietnam & Benin \\
\hline Benin & Namibia & Azerbaijan, Rep. & Republic & Zambia & Bolivia \\
\hline Bolivia & Nepal & Bahamas, The & Latvia & Zimbabwe & Brazil \\
\hline Botswana & $\begin{array}{l}\text { Netherlands } \\
\text { New }\end{array}$ & Bahrain, King. & Lesotho & & Burkina Faso \\
\hline Brazil & Zealand & Bangladesh & $\begin{array}{l}\text { Lithuania } \\
\text { Macedonia, }\end{array}$ & & Burundi \\
\hline Burkina Faso & Nicaragua & Barbados & FYR & & Cameroon \\
\hline Burundi & Niger & Belize & Madagascar & & $\begin{array}{l}\text { Canada } \\
\text { Central Afr. }\end{array}$ \\
\hline Cameroon & Nigeria & Benin & Malawi & & Rep. \\
\hline Canada & Norway & Bolivia & Malaysia & & Chad \\
\hline $\begin{array}{l}\text { Cape Verde } \\
\text { Central Afr. }\end{array}$ & Pakistan & Bosnia \& Herz. & Mali & & Chile \\
\hline Rep. & Panama & Botswana & Malta & & Costa Rica \\
\hline Chad & Papua N.G. & Brazil & Mauritania & & $\begin{array}{l}\text { Côte d'Ivoire } \\
\text { Dominican }\end{array}$ \\
\hline $\begin{array}{l}\text { Chile } \\
\text { China }\end{array}$ & Paraguay & Bulgaria & Mauritius & & Rep. \\
\hline (Mainland) & Peru & Burkina Faso & Mexico & & Ecuador \\
\hline Comoros & Philippines & Burundi & Moldova & & Egypt \\
\hline Congo, Rep. & Poland & Cameroon & Mongolia & & El Salvador \\
\hline
\end{tabular}




\begin{tabular}{|c|c|c|c|c|}
\hline Costa Rica & Portugal & $\begin{array}{l}\text { Canada } \\
\text { Central Afr. }\end{array}$ & Morocco & Ethiopia \\
\hline Côte d'Ivoire & Romania & Rep. & Mozambique & Fiji \\
\hline Cyprus & Rwanda & Chad & Myanmar & Gabon \\
\hline Denmark & Senegal & $\begin{array}{l}\text { Chile } \\
\text { China }\end{array}$ & Namibia & Ghana \\
\hline Dom.Republic & Seychelles & (Mainland) & Nepal & Guatemala \\
\hline Ecuador & Sierra Leone & Colombia & Netherlands & Guyana \\
\hline Egypt & South Africa & Congo, Rep. & New Zealand & Haiti \\
\hline El Salvador & Spain & Costa Rica & Nicaragua & Honduras \\
\hline Equat. Guinea & Sri Lanka & Côte d'Ivoire & Niger & India \\
\hline Ethiopia & $\begin{array}{l}\text { Sweden } \\
\text { Syrian Arab }\end{array}$ & Croatia & Nigeria & Indonesia \\
\hline Fiji & Rep. & Cyprus & Norway & Jamaica \\
\hline Finland & Tanzania & Czech Republic & Oman & Kenya \\
\hline France & Thailand & Denmark & Pakistan & Madagascar \\
\hline Gabon & $\begin{array}{l}\text { Togo } \\
\text { Trin.and }\end{array}$ & Dom. Rep & Panama & Malaysia \\
\hline Gambia, The & Tobago & Ecuador & Papua N. G. & Mali \\
\hline Germany & Tunisia & Egypt & Paraguay & Mauritania \\
\hline Ghana & Turkey & El Salvador & Peru & Mauritius \\
\hline Greece & $\begin{array}{l}\text { Uganda } \\
\text { United }\end{array}$ & Estonia & Philippines & Mexico \\
\hline Guatemala & $\begin{array}{l}\text { Kingdom } \\
\text { United }\end{array}$ & Ethiopia & Poland & Morocco \\
\hline Guinea & States & Fiji & Portugal & New Zealand \\
\hline Guinea-Bissau & Uruguay & Finland & Romania & Nicaragua \\
\hline Guyana & Venezuela & France & Russian Fed. & Niger \\
\hline Haiti & Zambia & Gabon & Rwanda & Nigeria \\
\hline Honduras & Zimbabwe & Georgia & Senegal & Pakistan \\
\hline Hungary & & Germany & Serbia, Rep. & Panama \\
\hline Iceland & & Ghana & $\begin{array}{l}\text { Sierra Leone } \\
\text { Slovak }\end{array}$ & Papua N.G. \\
\hline India & & Greece & Republic & Paraguay \\
\hline Indonesia & & Guatemala & Slovenia & Peru \\
\hline Iran, I.R. of & & Guinea-Bissau & South Africa & Rwanda \\
\hline Israel & & Guyana & Spain & Senegal \\
\hline Italy & & Haiti & Sri Lanka & Sierra Leone \\
\hline Jamaica & & Honduras & $\begin{array}{l}\text { Sweden } \\
\text { Syrian Arab, }\end{array}$ & South Africa \\
\hline Japan & & Hungary & Rep. & Sri Lanka \\
\hline Jordan & & Iceland & Tanzania & $\begin{array}{l}\text { Tanzania } \\
\text { Trin. and }\end{array}$ \\
\hline Kenya & & India & Thailand & Tobago \\
\hline Korea, Rep. & & Indonesia & $\begin{array}{l}\text { Togo } \\
\text { Trin.and }\end{array}$ & Tunisia \\
\hline Lesotho & & Iran, I.R. of & Tobago & Uganda \\
\hline Madagascar & & Israel & Tunisia & United States \\
\hline Malawi & & Italy & Turkey & Venezuela \\
\hline
\end{tabular}




\section{THOMAS JACK SNYDER}

March 11, 1982

2003

2003-2005

2005-2009

2008

2010
Born, Madera, California, U.S.A.

B.A., Economics. Summa Cum Laude

Florida State University

Tallahassee, Florida, U.S.A.

Intake Investigator

Florida Commission on Human Relations

Tallahassee, Florida, U.S.A.

Teaching Assistant

Doctoral Student. Department of Economics.

Florida International University

Miami, Florida, U.S.A.

M.A., Economics

Florida International University

Miami, Florida, U.S.A.

Dissertation Year Fellowship

Florida International University

Miami, Florida, U.S.A.

\section{PUBLICATIONS AND PRESENTATIONS}

Snyder, T. (February, 2010). Increasing Returns, Collateral, and Sovereign Debt. Paper presented at the Eastern Economic Association Conference in Philadelphia, Pennsylvania.

Snyder. T. (April, 2010). Increasing Returns, Collateral, and Sovereign Debt. Paper presented at the University of Central Arkansas in Conway, Arkansas. 